\author{
Universidade de Brasília \\ Instituto de Ciências Exatas \\ Departamento de Matemática
}

\title{
Contextualização histórica para o estudo da trigonometria e construção do teodolito no Ensino Fundamental
}

\author{
por \\ Evelyn Gabrielle Monteiro Gomes da Silva
}


Universidade de Brasília

Instituto de Ciências Exatas

Departamento de matemática

\section{Contextualização histórica para o estudo da trigonometria e construção do teodolito no Ensino Fundamental}

por

Evelyn Gabrielle Monteiro Gomes da Silva *

Dissertação apresentada ao Departamento de Matemática da Universidade de Brasília, como parte dos requisitos do "Programa" de Mestrado Profissionalizante em Matemática em Rede Nacional - PROFMAT, para obtenção do grau de

\section{MESTRE}

Brasília, 09 de novembro de 2015

Comissão Examinadora:



*O autor foi bolsista do CAPES durante a elaboração deste trabalho. 
Ficha catalográfica elaborada automaticamente,

\section{com os dados fornecidos pelo(a) autor(a)}

Monteiro Gomes da Silva, Evelyn Gabrielle

Contextualização histórica para o estudo da

MEV93c trigonometria e construção do teodolito no Ensino

Fundamental / Evelyn Gabrielle Monteiro Gomes da

Silva; orientador Ricardo Ruviaro. -- Brasília, 2015.

$97 \mathrm{p}$.

Dissertação (Mestrado - Mestrado Profissional em Matemática) -- Universidade de Brasília, 2015.

1. Contextualização histórica. 2. Trigonometria. 3. Teodolito. 4. Educação. 5. Ensino da Matemática. I. Ruviaro, Ricardo, orient. II. Título. 
"A matemática é o alfabeto com o qual Deus escreveu o universo" Pitágoras 


\section{Agradecimentos}

Nesse momento tão especial e importante em minha vida, venho prestar minhas homenagens e agradecimentos a todos que de alguma forma fizeram diferença durante esses anos.

Agradeço primeiramente a Deus pelo dom da vida e da inteligência, bem como pelas infinitas bênçãos concedidas durante esses dois anos de intensos estudos e dedicação.

Agradeço aos meus familiares, pai, mãe e irmãos pelo apoio incondicional e compreensão pela minha ausência durante todo esse tempo. Um muito obrigada, em especial, a minha querida irmã Etiene, por ter realizado toda a revisão ortográfica desse trabalho.

Aos meus colegas e amigos de PROFMAT, um sentimento de gratidão e alegria por terem depositado tanta confiança em minha pessoa para representar a nossa turma diante da coordenação do curso e por estarem dispostos a me auxiliar nos estudos.

Uma grande homenagem ao meu grande amigo e orientador, Dr. Ricardo Ruviaro, pelos infinitos conselhos, ajudas, motivações e até pequenas broncas durante a realização desse trabalho. Sem você este trabalho não teria ficado tão bom. Muito obrigada por ter acreditado nas minhas ideias e ter me apoiado com suas devidas exigências. Serei eternamente grata a você.

Ao corpo docente do Departamento de Matemática da UnB, um agradecimento por terem feito um grande diferencial em minha vida: Lineu Neto, Ary Vasconcelos, Diego Marques, Angel Rodolfo Baigorri, Helder Matos, Carlos Alberto, Mauro Rabelo, Kellcio Oliveira e o coordenador Rui Seimetz a minha mais sincera gratidão!

Agradeço à CAPES pelo apoio financeiro a este trabalho. E, claro, um agradecimento à Secretaria de Educação do Distrito Federal por ter me concedido o afastamento para a realização desses estudos, o que possibilitou que eu tivesse maior aproveitamento nas disciplinas e maior dedicação no curso.

Enfim, agradeço a todos que de alguma forma contribuíram para a elaboração desse trabalho e conclusão do PROFMAT. 


\section{Resumo}

A Trigonometria nasceu, aproximadamente, em 300 a.C. entre os gregos, para resolver problemas de astronomia, passando, aproximadamente, em 400 d.C., para a Índia onde foi usada nos cálculos astrológicos. Por cerca dos anos 800 d.C. ela chegou ao mundo islâmico, onde foi muito desenvolvida e aplicada na astronomia e cartografia. Por volta de 1100 d.C. a Trigonometria chegou junto com os livros de Ptolomeu, na Europa Cristã onde inicialmente foi estudada tão somente por suas aplicações à Astronomia. Nos dias de hoje, é estudada primeiramente no $9^{\circ}$ ano do Ensino Fundamental, onde muitas vezes os professores não fazem aplicações e mostram somente as razões trigonométricas. A partir desse cenário e buscando desmistificar essa maneira tradicional e que há décadas e, até mesmo, séculos, vêm a demonstrar resultados não tão positivos encontra-se, nesse trabalho, uma aplicação válida da Trigonometria através da construção do teodolito que é um instrumento óptico utilizado na topografia, para realizar medidas de ângulos verticais e horizontais com o objetivo de facilitar o cálculo de distâncias e alturas. Empregado na Geodésia e na Agrimensura para triangulação em redes, o instrumento é também usado pela engenharia, arquitetura e por outros profissionais e técnicos, em grandes construções de estradas, demarcações de fazendas e sítios (em [24]). Dessa forma, esse trabalho tem como objetivos fazer um apanhado histórico da Educação do Brasil e a evolução do ensino da Matemática no Brasil desde o período colonial até os dias atuais, uma construção de conhecimentos matemáticos necessários ao aprendizado da Trigonometria para alunos do $9^{\circ}$ ano do Ensino Fundamental através de atividades contendo contextualizações históricas sobre cada assunto abordado, mostrar a viabilidade de se trabalhar fora do ambiente de sala de aula através da construção e utilização do Teodolito com o intuito de motivar o aprendizado desse conteúdo tão importante e o ensino da Matemática de uma maneira geral.

Palavras-Chaves: Trigonometria; Teodolito; Educação; Ensino da Matemática; Contextualização histórica. 


\section{Abstract}

We can trace Trigonometry back to approximately 300 BC, when the Greeks used very simple relations to solve astronomy problems. It eventually reached India around $400 \mathrm{AD}$, used in astrological calculations. By the eighth century we can find many uses of Trigonometry in the Islamic world, where it was greatly developed and applied in astronomy and cartography. Around 1100 AD Trigonometry came to Christian Europe, brought with Ptolemy's books. There in initially studied solely by its applications to astronomy. It is introduced in the 9th grade (junior high school in Brazil), where teachers typically do not work with real world applications, limiting themselves and the students to trigonometric ratios. This old scenario has led to bad results for many decades. We thus suggest as a real application the construction of a theodolite, an optical instrument used in topography to measure vertical and horizontal angles in order to facilitate the calculation of distances and heights. It is employed in geodesy and triangulation for land surveying and is used by engineers, architects and other professionals and technicians in building large roads and in boundary surveying of parcels (in [24]). The aims of this work are: 1) to survey the historical evolution of how we have been teaching Math in Brazil since the XIX century; 2) build the basis of the mathematical knowledge necessary for 9th graders to learn Trigonometry . We propose a bunch of contextualized activities that are historically based and we show it is possible to make this approach outdoors. In order to reach these goals, we will construct and use a prototype of a theodolite in order to engage students in learning this important issue and in studying mathematics in general.

Key-Words: Trigonometry; Theodolite; Education; Teaching; Mathematics; Historical Contextualization. 


\section{Sumário}

$\begin{array}{lr}\text { Introdução } & 1\end{array}$

1 Uma breve história da Educação 3

1.1 A história da Educação no Brasil . . . . . . . . . . . . . . 4

1.2 Cenário atual da educação no Brasil . . . . . . . . . . . . . . . . 9

1.3 A evolução do ensino da Matemática no Brasil . . . . . . . . . . . . . . 12

1.4 Dificuldades de aprendizagem em Matemática . . . . . . . . . . . 15

$1.5 \quad$ O papel do professor . . . . . . . . . . . . . . . . . 19

2 A Trigonometria e o Teodolito 22

2.1 Breve histórico da Trigonometria $\ldots \ldots \ldots \ldots \ldots \ldots$

2.2 Breve histórico do Teodolito . . . . . . . . . . . . . . . 25

2.3 Trigonometria nas escolas . . . . . . . . . . . . . . 27

2.4 Trigonometria e a Pedagogia . . . . . . . . . . . . . 28

3 Metodologia do projeto $\quad 29$

$3.1 \quad$ o projeto . . . . . . . . . . . . . . . . . . 29

3.2 o local . . . . . . . . . . . . . . . . . 30

3.3 Os participantes . . . . . . . . . . . . . . . . . . 31

3.4 Atividades Desenvolvidas . . . . . . . . . . . . . . . . . . 31

3.4.1 Atividade 1: Raiz quadrada . . . . . . . . . . . . . . 32

3.4 .2 Atividade 2: Média Aritmética . . . . . . . . . . . 32

3.4.3 Atividade 3: Dízima periódica . . . . . . . . . . . . . . 32

3.4.4 Atividade 4: Medidas de comprimento . . . . . . . . . . 33

3.4.5 Atividade 5: Regra de três simples . . . . . . . . . . . . 33

3.4 .6 Atividade 6: Teorema de Pitágoras . . . . . . . . . . . 33

3.4.7 Atividade 7: Ângulo e Transferidor . . . . . . . . . . . . . . 33

3.4 .8 Atividade 8: Compasso . . . . . . . . . . . . . . . . 34

3.4 .9 Atividade 9: Trigonometria . . . . . . . . . . . . . 34

3.4.10 Atividade 10: Construção do Teodolito e aplicação dos conceitos de Trigonometria . . . . . . . . . . . . . . 34

3.4 .11 Atividade 11: Pesquisa de opinião . . . . . . . . . . . 34 
4 Análise de Resultados 35

4.1 Análise Quantitativa das Atividades . . . . . . . . . . . . 35



4.1.2 Atividade 2: Média Aritmética . . . . . . . . . . . 36

4.1.3 Atividade 3: Dízima Periódica . . . . . . . . . . 38

4.1.4 Atividade 4: Medidas de comprimento . . . . . . . . . . . 40

4.1.5 Atividade 5: Regra de três simples . . . . . . . . . . . . . . 41

4.1.6 Atividade 6: Teorema de Pitágoras . . . . . . . . . . . . . . . 42

4.1.7 Atividade sete: Ângulo e transferidor . . . . . . . . . . . . . . . 44

4.1.8 Atividade 8: Compasso . . . . . . . . . . . . . . . . 45

4.1.9 Atividade 9: Trigonometria ................ 46

4.1.10 Atividade 10: Construção do Teodolito e aplicação dos conceitos de





4.3 Análise da Pesquisa de Opinião . . . . . . . . . . . . . . . . . 49

5 Considerações Finais $\quad 54$

6 Apêndice A $\quad 56$

$\begin{array}{ll}\text { Referências Bibliográficas } & 94\end{array}$ 


\section{Introdução}

Este trabalho faz um apanhado histórico sobre a história da Educação no Brasil, a evolução do Ensino da Matemática no Brasil e as dificuldades de aprendizagem em Matemática para dar um suporte ao principal assunto desenvolvido que é o ensino da Trigonometria no $9^{\circ}$ ano do Ensino Fundamental através da realização de atividades que levaram ao desenvolvimento do conhecimento e a construção do teodolito com os alunos.

Apesar de o trabalho ter sido desenvolvido em Brasília, uma frase do currículo do Estado de São Paulo exemplifica bem o porquê de ter se iniciado com a história da Matemática no Brasil e de se ter trabalhado sempre com a contextualização histórica de cada assunto desenvolvido em sala de aula:

A Matemática, sua história e sua cultura são um exemplo candente de equilíbrio entre a conservação e a transformação, no que tange aos objetos do conhecimento. Uma máquina a vapor ou um computador IBM 360 certamente têm, hoje, interesse apenas histórico, podendo ser associados a peças de museu. O Teorema de Pitágoras, o binômio de Newton e a relação de Euler, no entanto, assim como os valores humanos presentes em uma peça de Shakespeare, permanecem absolutamente atuais. (Currículo de Matemática do Estado de São Paulo, 2012, p.34).

Dessa forma, foi desenvolvido um projeto com alguns alunos do $9^{\circ}$ ano de uma escola do Distrito Federal, a qual norteia-se pelos princípios e fins da educação estabelecidos na Lei de Diretrizes e Bases da Educação Nacional, respeitando a legislação correlata vigente e superveniente, visando o pleno desenvolvimento do educando, seu preparo para o exercício da cidadania e a sua preparação geral para o mundo do trabalho. Nesse sentido, segundo Anísio Teixeira:

O ato de aprender, durante muito tempo significou simples memorização; depois seu sentido passou a incluir a compreensão e expressão do que fora ensinado; por último, envolveu algo mais: ganhar um modo de agir. Só aprendemos quando assimilamos uma coisa de tal jeito que, chegado o momento oportuno, sabemos agir de acordo com o aprendido. Não se aprendem apenas ideias ou fatos, mas também atitudes, 
ideais e senso crítico - desde que a escola disponha de condições para exercitá-los.

Assim, o projeto que consistia na aplicação de 10 atividades contextualizadas para serem desenvolvidas durante 50 minutos, abordando temas tais como raiz quadrada, medidas de comprimento e uso do compasso, foi aplicado com o intuito de estimular e dar um incentivo a mais para o ensino da Matemática, em especial o ensino da trigonometria para o $9^{\circ}$ ano do ensino fundamental, mostrando aos alunos que é possível associar a história da matemática com aulas práticas e atividades propostas em sala.

Durante o primeiro semestre do ano de 2015, os alunos desenvolveram as 10 atividades em sala de aula, tendo a oportunidade de verificarem o que já tinham de conhecimento sobre cada assunto com as questões de sondagem, depois verificaram os erros e acertos comparando com o desenvolvimento dos colegas e, após a explanação do conteúdo pela professora, puderam responder as demais questões. Além disso, a curiosidade dos alunos foi despertada com a história de cada conteúdo para que pudessem conhecer como surgiu a Matemática.

Visando melhor entendimento e aplicabilidade deste trabalho, o Capítulo 1 trata sobre a história da educação, onde o leitor encontrará desde o histórico da Educação no Brasil, o cenário atual da Educação no Brasil até o papel do professor em sala de aula. Para o Capítulo 2, foi feito um breve apanhado histórico sobre a Trigonometria e o Teodolito, este último, tomando como base informações do MAST, Museu de Astronomia e Ciências Afins.

O leitor encontrará uma abordagem detalhada, no Capítulo 3, sobre a metodologia aplicada no desenvolvimento das atividades e, finalmente, no Capítulo 4 está exposto a análise de resultados dos trabalhos desenvolvidos com os alunos, bem como a opinião deles quanto à realização do projeto. 




Piaget (em [12]) afirma que a Educação deve possibilitar à criança um desenvolvimento amplo e dinâmico desde o período sensório-motor até o operatório abstrato e que, para construir esse conhecimento, as concepções infantis combinam-se às informações advindas do meio, na medida em que o conhecimento não é concebido apenas como sendo descoberto espontaneamente pela criança, nem transmitido de forma mecânica pelo meio exterior ou pelos adultos, mas como resultado de uma interação na qual o sujeito é sempre um elemento ativo, que procura ativamente compreender o mundo que o cerca, e que busca resolver as interrogações que esse mundo provoca. É aquele que aprende basicamente através de suas próprias ações sobre os objetos do mundo e que constrói suas próprias categorias de pensamento ao mesmo tempo em que organiza seu mundo. Não é um sujeito que espera que alguém que possui um conhecimento o transmita a ele por um ato de bondade. Assim, Piaget conceitua que educar (em [12] p. 62) seria "estimular a estruturação de formas de ação (motora, verbal e mental) cada vez mais móveis, mais amplas e mais estáveis, com a finalidade de extensão progressiva do organismo."

Para Piaget, os principais objetivos da educação são a formação de homens "criativos, inventivos e descobridores" (em [12]), de pessoas críticas e ativas, e na busca constante da construção da autonomia. Assim, a educação tem importância fundamental no desenvolvimento humano e a forma de educar, ou de transmitir conhecimentos por suas imensas variáveis, torna-se o ponto chave para a construção ou para a desconstrução de um ser humano.

Porém, o que se percebe atualmente nas escolas é algo bem diferente do que Piaget acreditava. Segundo os Parâmetros Curriculares Nacionais (em [2]), o professor precisa cumprir determinado cronograma e apresentar determinada quantidade de conteúdos aos 
alunos. Assim, por falta de estrutura nas escolas a educação acaba se baseando na transmissão de conhecimentos, tornando as aulas expositivas e não interessantes, por não terem nenhuma contextualização com o dia a dia do aluno. Dessa forma, o professor não está valorizando as concepções e experiências advindas de cada aluno nem o ajudando a ser um indivíduo crítico e criativo. Mas isso não significa que a culpa seja do professor ou do aluno. Muito precisa ser mudado na educação brasileira, principalmente no ensino da Matemática. Mas como fazer para mudar essa realidade? Um bom começo é analisar o que acontece no meio escolar e valorizar as experiências dos alunos, tentando contextualizar, na medida do possível, os conteúdos trabalhados em sala de aula.

\subsection{A história da Educação no Brasil}

No início da colonização do Brasil (em [25]), as primeiras salas de aula foram criadas pelos jesuítas para evangelizar os índios, conforme escrevem Amarilio Ferreira Jr. e Marisa Bittar, docentes da Universidade Federal de São Carlos (Ufscar), no artigo A Gênese das Instituições Escolares no Brasil (em [36]) "logo após o desembarque, os jesuítas iniciaram a conversão dos índios ao cristianismo ensinando os rudimentos do ler e escrever, numa concepção evangelizadora que se materializaria, depois, nos famosos catecismos bilíngues, em tupi e português"

Entre os séculos XVI e XVIII, os jesuítas lideraram as primeiras experiências de ensino no Brasil, mas foram expulsos de Portugal e da Colônia em 1759. Assim, o marquês de Pombal, Sebastião José de Carvalho e Melo (1699-1782), iniciou uma reforma da Educação com o objetivo de modernizar o reino de dom José I (1714-1777). Para substituir os padres, ele criou as aulas régias, que só duraram até a morte de dom José I, em 1777. Quando dona Maria I (1734-1816) assumiu o trono, demitiu o marquês. Apesar da mudança política, no início não houve uma ruptura no sistema de ensino: as aulas deixaram de ser denominadas régias e passaram a ser chamadas de públicas, mas só o nome mudou.

A Constituição de 1824 estabeleceu que a Educação deveria ser gratuita para todos os cidadãos e, para cumprir essa determinação, deputados e senadores aprovaram uma lei em 15 de outubro de 1827 que marcou o Dia do Professor (em [25]) e indicou que fossem criadas escolas de primeiras letras em todas as cidades e vilas. Como parte do esforço de criar mais escolas, o Colégio Pedro II foi fundado em 1837, no Rio de Janeiro, para ser um modelo para o ensino secundário. E para quem iniciava os estudos, havia as escolas de primeiras letras. Nelas, as aulas abordavam temas como a leitura, a escrita e as operações matemáticas e adotavam o método mútuo ou lancasteriano, como na Figura 1.1 a seguir, criado na Inglaterra e muito usado no Brasil na primeira metade do século 19. 




Figura 1.1: O método mútuo, inspirado no sistema fabril inglês

Na segunda metade do século XIX, várias reformas tentaram dar um rumo mais profícuo para a Educação. Outros métodos foram utilizados, como o simultâneo, em que o professor se dirige a grupos de alunos reunidos pelo tema a ser estudado, e o intuitivo, que propunha o uso dos cinco sentidos para o aprendizado.

Assim, no fim do período colonial e durante o Império, o ensino se tornou estatal e os professores foram muito cobrados, mas pouco recompensados.

Com a Constituição de 1891, a União ficou responsável apenas pela Educação no Distrito Federal (então, o Rio de Janeiro), como comenta Romualdo Portela no livro Educação e Federalismo no Brasil: Combater as Desigualdades e Garantir a Diversidade "os estados mais ricos assumem diretamente a responsabilidade pela oferta de ensino e os mais pobres repassam-na para seus municípios, ainda mais pobres".

Em 1892, a reforma paulista propõe os grupos escolares, com a divisão dos alunos em séries, como Figura 1.2 a seguir.



Figura 1.2: grupos escolares divididos por idade e série

A ideia de uma Educação para todos só ganhou força na década de 1920. Nesse período, se destacaram os pioneiros da Escola Nova - Anísio Teixeira (1900-1971), Fernando de Azevedo (1894-1974), Lourenço Filho (1897-1970) e outros -, que defendiam a escola pública e laica, igualitária e sem privilégios, conforme afirma Anísio Teixeira: 
Não pode ser uma escola de tempo parcial, nem uma escola somente de letras, nem uma escola de iniciação intelectual, mas uma escola sobretudo prática, de iniciação ao trabalho, de formação de hábitos de pensar, hábitos de fazer, hábitos de trabalhar e hábitos de conviver e participar em uma sociedade democrática, cujo soberano é o próprio cidadão.

A defesa da Educação pública, gratuita e laica ganhou força no país em 1932, com o Manifesto dos Pioneiros da Educação Nova, no governo Getúlio Vargas. Segundo Maria Cristina Gomes Machado, da Universidade Estadual de Maringá (UEM) (em [25]) "o principal mérito do manifesto foi trazer à tona o debate sobre a escola para toda a população independentemente da classe social".

Em 1930, foi criado o Ministério da Educação e Saúde Pública, ocupado por Francisco Campos. Embora influenciado pelo manifesto, o novo ministro era católico e antiliberal. Assim, colaborou para o retorno do Ensino Religioso ao currículo. Além da presença na escola pública, a religião exercia influência no ensino privado, pois as igrejas, principalmente a católica, eram proprietárias de muitas instituições e recebiam subvenção do governo. Os escolanovistas eram contra isso e os dois grupos protagonizaram intensos debates.

Em 1937, as doutrinas totalitaristas se expandiam na Europa e, inspirado por elas, Vargas instituiu o Estado Novo, conforme esclarece Silvia Helena Andrade de Brito no artigo A Educação no Projeto Nacionalista do Primeiro Governo Vargas "a nova ideologia proclamava a importância da escola como via de reconstrução da sociedade brasileira".

Em 1939, o primeiro curso de Pedagogia do país foi criado na PUC, em Campinas. Muitas mulheres atuavam como professoras nos anos iniciais, mas acabavam abandonando a atividade quando se casavam. Então percebia-se uma maior quantidade de professores do sexo masculino e acontecia a separação de gêneros entre os alunos nas salas de aula, conforme Figura 1.3.

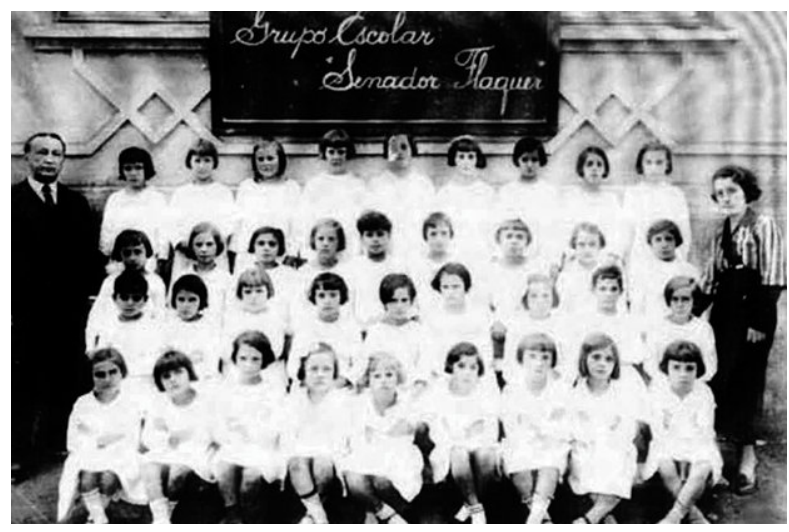

Figura 1.3: Salas separadas por gênero 
Assim, as Leis Orgânicas do Ensino foram promulgadas a partir de 1942. O ginásio, equivalente ao segundo ciclo do Ensino Fundamental de hoje, passou a ter quatro anos e o colegial - o atual Ensino Médio - três. Foi criado o curso supletivo de dois anos para a população adulta. E a rede pública foi organizada em escolas com uma, duas a quatro e cinco ou mais classes, além da escola supletiva.

Com o fim do Estado Novo, o País ganhou outra Constituição, que atribuiu à União a função de legislar sobre as bases da Educação, o que antes ocorria de maneira fragmentada. Em 1948, o ministro Clemente Mariani (1900-1981) apresentou o anteprojeto da Lei de Diretrizes e Bases da Educação Nacional (LDBEN), o que gerou novos conflitos entre os escolanovistas e a Igreja Católica. Por causa desses conflitos, a LDBEN foi aprovada, somente, 13 anos depois, permitindo a pluralidade dos currículos e estabelecendo que o Estado destinaria recursos a entidades privadas.

Nos anos 1950 e 1960, surgiram movimentos de Educação popular, com iniciativas que até hoje estão vivas, como as propostas de Paulo Freire (1921-1997). As primeiras experiências do educador ocorreram em 1962, em Angicos, a 171 quilômetros de Natal, quando 300 trabalhadores rurais foram alfabetizados em 45 dias. Freire considerava as cartilhas incapazes de atender às necessidades dos alunos. Para ele, na sociedade de classes, os privilégios de uns impedem a maioria de usufruir de certos bens, como a Educação, que deveria instigar a reflexão sobre a própria condição social. No livro Pedagogia do Oprimido, 1967, Freire diz

Na visão bancária da Educação, o 'saber' é uma doação dos que se julgam sábios aos que julgam nada saber. (...) O educador, que aliena a ignorância, se mantém em posições fixas, invariáveis. Será sempre o que sabe, enquanto os educandos serão sempre os que não sabem. A rigidez dessas posições nega a Educação e o conhecimento como processos de busca.

As propostas de uma Educação mais democrática foram abandonadas com o início do regime militar, em 1964. Paulo Freire (1921-1997) foi exilado no Chile e o novo governo manteve o foco em formar um povo capaz de executar tarefas, mas não necessariamente de pensar sobre elas.

No primeiro ano de mandato do marechal Humberto de Alencar Castello Branco (19001967), foi realizado um simpósio do Instituto de Pesquisas e Estudos Sociais (Ipes), ligado à direita governista, no qual a meta do evento era a elaboração de um plano de Educação com a escola primária voltada para uma atividade prática e o $2^{\circ}$ grau técnico que preparasse o estudante para o mercado, segundo Dermeval Saviani conta no livro História das Ideias Pedagógicas no Brasil.

Na Educação de adultos, as ideias de Freire deram lugar a um modelo assistencia - 
lista por meio do Movimento Brasileiro de Alfabetização ${ }^{1}$. A leitura passou a ser tratada como uma habilidade instrumental, sem contextualização. Também eram estudados os cálculos matemáticos, a escrita e hábitos para a melhoria da qualidade de vida.

No fim de 1968, o general Arthur da Costa e Silva (1902-1969), na presidência, promulgou o Ato Institucional $\mathrm{n}^{\circ} 5$ (AI-5), que deu a ele poderes de legislativo e executivo e permitiu o confisco dos bens de quem fosse incriminado por corrupção. E, no ano seguinte, o Decreto-lei no 477 determinou que "comete infração disciplinar o professor, aluno, funcionário ou empregado de estabelecimento de ensino público ou particular que pratique atos destinados à organização de movimentos subversivos, passeatas, desfiles ou comícios não autorizados". Muitos estudantes e docentes foram presos e torturados por aderirem à oposição ao governo.

Em julho de 1971, o então ministro da Educação e Cultura, Jarbas Passarinho, oficializou o vestibular classificatório nas universidades, algo que se mantem até hoje. No mês seguinte, foi aprovada a Lei $\mathrm{n}^{0} 5.692$, que determinava a organização do ensino em $1^{\circ}$ e $2^{\circ}$ graus em vez de primário, ginásio e colegial, conforme suas próprias palavras:

Agora, vossa excelência [presidente Médici] não proporá ao Congresso Nacional apenas mais uma reforma, mas a própria reforma que implica abandonar o ensino verbalístico e academizante, para partir, vigorosamente, para um sistema educativo de $1^{\circ}$ e $2^{\circ}$ graus voltado para as necessidades do desenvolvimento.

Com o fim da ditadura militar, vários aspectos da política nacional foram repensados, e entre eles estava a Educação. Em 5 de outubro de 1988, a nova Constituição Federal foi aprovada. Entre as principais conquistas, estava o reconhecimento da Educação como direito subjetivo de todos, uma evolução que os escolanovistas haviam propagado durante a Era Vargas.

No governo de Fernando Henrique Cardoso (FHC), em 1996, foi promulgada a Lei de Diretrizes e Bases da Educação Nacional (LDB), com relatoria do senador Darcy Ribeiro, que indicou que docentes tivessem formação em nível superior, o $1^{\circ}$ e o $2^{\circ}$ graus se tornaram Ensino Fundamental e Médio e a recomendação para os estudantes com necessidades especiais passou a ser a de que fossem atendidos preferencialmente na rede regular.

No segundo mandato de FHC, o então ministro Souza incluiu o Brasil no Programa Internacional de Avaliação de Alunos (PISA). Foi um passo importante para se ter um medidor de como estava a Educação Nacional, embora o país tenha ficado em último lugar

\footnotetext{
${ }^{1}$ O Movimento Brasileiro de Alfabetização (MOBRAL) foi um projeto do governo brasileiro, criado pela Lei 5379, de 15/11/1967, e propunha a alfabetização funcional de jovens e adultos, visando "conduzir a pessoa humana a adquirir técnicas de leitura, escrita e cálculo como meio de integrá-la a sua comunidade, permitindo melhores condições de vida".
} 
no ano de estreia. Na mesma época, criou-se o Exame Nacional de Ensino Médio (Enem), com resultados por escola e por aluno, que, em 2009, passariam a ser considerados até em substituição ao vestibular para o Ensino Superior. Os Parâmetros Curriculares Nacionais (PCN) e o Referencial Curricular Nacional para a Educação Infantil (RCNEI) também nasceram nesse período.

Em 2001, entrou em vigor o Plano Nacional de Educação (PNE), com metas para a universalização do ensino e, em 2005, outro exame nacional foi criado: a Prova Brasil, onde alunos de $4^{\mathrm{a}}$ e $8^{\mathrm{a}}$ séries $\left(5^{\circ}\right.$ e $9^{\circ}$ anos) também passaram a ser avaliados.

\subsection{Cenário atual da educação no Brasil}

Segundo a Revista Carta Capital de 14 de abril de 2014 (em [13]), numa pesquisa de opinião, quando foi perguntado à população brasileira qual seria o problema fundamental do Brasil, a maioria indicou a precariedade da educação. Os entrevistados apontaram que o sistema educacional brasileiro não é capaz de preparar os jovens para a compreensão de textos simples, elaboração de cálculos aritméticos de operações básicas, conhecimento elementar de Física e Química, e outros fornecidos pelas escolas fundamentais. A revista ainda afirma que os pais expressavam o desejo de ter bons professores, salas de aula com poucos alunos, mas não se sentiam responsáveis para participarem ativamente das atividades educacionais, inclusive custeando os seus serviços.

Em 2012, em uma avaliação de aprendizagem em larga escala, que avalia a qualidade da educação, o PISA, realizada em 65 países, o Brasil ficou entre as últimas posições do ranking, mostrando que o país ainda tem muito a evoluir na educação.

O PISA (em [26]), Programa Internacional de Avaliação de Estudantes, é uma avaliação aplicada pela Organização para Cooperação e Desenvolvimento Econômico (OCDE) para medir o nível de habilidades de estudantes de diferentes países em três áreas do conhecimento: matemática, leitura e ciência. O exame ocorre a cada três anos para alunos na faixa etária dos 15 anos, sendo que a cada edição o foco está centrado em uma área principal a ser avaliada. Na edição de 2000, o foco foi em leitura; em 2003, em matemática; em 2006, em ciências; em 2009, repetiu-se a área de leitura; e em 2012, o foco foi novamente em matemática. Apesar de não ser um país-membro da OCDE, o Brasil participa do PISA desde 2000, mesmo tendo ficado na última posição nesse ano. O desempenho do país evoluiu nas últimas edições, mas os alunos brasileiros ainda ocupam as últimas posições do ranking do PISA, conforme na Figura 1.4 a seguir. 




Figura 1.4: Tabela de comparação

Algumas conclusões retiradas do PISA 2012:

a) Embora o Brasil ainda esteja abaixo da média dos países desenvolvidos, foi o país que mais melhorou a média em Matemática desde 2003. Em leitura e ciências também houve melhora significativa;

b) O Brasil também expandiu a adesão às escolas de Ensino Fundamental e Médio desde 2003 , indo de $65 \%$ a $78 \%$ nos alunos de 15 anos;

c) Altas taxas de repetência ainda são encontradas em todo Brasil, especialmente entre alunos mais pobres, e estão negativamente associadas ao desempenho em Matemática (ou seja, quanto maior a repetência de uma rede de ensino, piores são as notas em Matemática dos seus alunos).

Além das conclusões obtidas pelo PISA, vários especialistas em educação veem diversas falhas e problemas na educação brasileira, que começam a ser percebidas pela população brasileira, tais como gestão ineficiente, desprestígio do magistério, má formação de professores, baixo investimento na educação básica, pouca inovação na sala de aula, baixa participação da comunidade escolar, entre outros. Segundo o economista Claudio de Moura Castro, (em [27]), "temos de levar em conta que começamos a nos preocupar com educação com quatro, cinco séculos de atraso em relação a outros países. É impossível recuperar isso do dia para a noite, mas temos de investir melhor para não perdermos mais tempo".

Assim, para que haja mudanças na educação brasileira, é preciso que a sociedade como um todo esteja convencida que todos precisam contribuir para tanto, inclusive elegendo representantes que partilhem desta convicção e não estejam pensando somente nos seus benefícios pessoais. 
Segundo a revista ISTOÉ, (em [14]), que se baseou na $1^{\mathrm{a}}$ Análise do SEADE (Fundação Sistema Estadual de Análise de Dados), disponível (em [37]), o maior problema da educação brasileira está na evasão escolar, com base em informações da Pesquisa Nacional por Amostra de Domicílios do IBGE, revela que apenas metade dos jovens com idade entre 15 anos e 17 anos está matriculada no Ensino Médio. Entre os anos 1999 e 2011, a taxa de evasão nesta faixa etária mais que dobrou, saltando de $7,2 \%$ para $16,2 \%$. "Chama a atenção a dificuldade de enfrentamento da crise do Ensino Médio", resume o estudo. "A despeito das reformas, os resultados das avaliações nacionais continuam surpreendendo negativamente os responsáveis pela condução da política educacional brasileira", dada na Figura 1.5.



Figura 1.5: Evasão escolar 


\subsection{A evolução do ensino da Matemática no Brasil}

Em 1549 (em [6]), o primeiro grupo de jesuítas, liderados pelo padre Manuel da Nóbrega, chegou no Brasil, sendo os responsáveis pela criação da primeira escola elementar, em Salvador. Em respeito aos conhecimentos matemáticos, nas escolas elementares contemplava-se o ensino da escrita dos números no sistema de numeração decimal e o estudo das operações de adição, subtração, multiplicação e divisão de números naturais. Nos colégios, havia pouco espaço para os conhecimentos matemáticos e grande destaque para o aprendizado do latim. Sobre o ensino desses conhecimentos, conhece-se pouco: por exemplo, sabe-se que a biblioteca do colégio dos jesuítas no Rio de Janeiro possuía muitos livros de Matemática. No entanto, estudos realizados por muitos pesquisadores conduzem à ideia geral de que os estudos matemáticos eram realmente pouco desenvolvidos no ambiente jesuíta.

Com a expulsão dos jesuítas do Brasil, em 1772, um alvará do marquês de Pombal criou as aulas régias, nas quais se ensinaram primeiramente a gramática, o latim, o grego, a filosofia e a retórica, e, posteriormente, as disciplinas matemáticas: aritmética, álgebra e geometria. Eram aulas avulsas, e, em relação aos conhecimentos matemáticos, há indícios de que havia poucos alunos e, também, que era difícil conseguir professores. Ou seja, nesse período o número de aulas de Matemática era pequeno e essas aulas tinham baixa frequência.

No fim do século XVIII, um destaque à Matemática e às ciências foi a criação do Seminário de Olinda pelo bispo de Pernambuco, Dom Azeredo Coutinho, em 1798. Essa instituição, que funcionou a partir do ano de 1800 e não formava somente padres, tornouse uma das melhores escolas secundárias do Brasil. Ela conferiu importância ao ensino dos temas matemáticos e científicos, e era estruturada em termos de sequenciamento dos conteúdos, duração dos cursos, reunião dos estudantes em classes e trabalho de acordo com um planejamento prévio.

Após a Independência do Brasil (em [6]), a lei de 15 de outubro de 1827 diferenciou a educação para meninos e meninas prevendo escolas separadas para os dois sexos. O currículo para as escolas de meninos envolvia "ler, escrever, as quatro operações aritméticas, prática de quebrados, decimais e proporções, noções gerais de geometria, gramática da língua nacional, moral cristã e doutrina católica" (Art 6). As escolas para meninas existiriam nas localidades mais populosas, seriam dirigidas por professoras e em seu currículo eliminava-se a geometria e a prática de quebrados, incluindo-se o ensino de práticas importantes para a economia doméstica.

Em 1837, o ministro Bernardo Pereira de Vasconcelos criou o Imperial Colégio de 
Pedro II, que dava o grau de bacharel em letras aos alunos aprovados em todas as disciplinas durante os sete anos do curso e dispensava os alunos concluintes dos exames de ingresso aos cursos superiores. As matemáticas, que eram as disciplinas de Aritmética, Álgebra, Geometria, e, posteriormente a Trigonometria, apesar do predomínio das disciplinas literárias e humanistas, estavam presentes em todas as séries do curso do Colégio de Pedro II.

Enquanto as filhas das classes privilegiadas eram educadas para as atividades do lar e para a convivência social em colégios femininos, as filhas das classes populares podiam frequentar as aulas de instrução elementar, as escolas normais (para formação de professores) e cursos profissionalizantes. Na década de 1880, algumas mulheres passaram a estudar no Colégio Pedro II e, em 1887, a primeira mulher recebeu o diploma de médica no Rio de Janeiro, sendo a única presença feminina na turma.

Em 1890, Benjamin Constant (1836-1891), primeiro titular do Ministério da Instrução, Correios e Telégrafos, foi o responsável por uma reforma no ensino, consubstanciada no Decreto 981, que buscava romper com a tradição humanista e literária do ensino secundário pela adoção de um currículo que privilegiava as disciplinas científicas e matemáticas. A Matemática era tida como a mais importante das ciências no ideário positivista do filósofo francês Auguste Comte (1798-1857), ao qual aderiram Benjamin Constant e o grupo de militares brasileiros que liderou a proclamação da República.

Em Roma, em 1908 (em [6]), realizou-se o $4^{\circ}$ Congresso Internacional de Matemática, no qual foi criada uma comissão internacional para tratar de questões do ensino, presidida pelo matemático alemão Felix Klein (1849-1925). Essa comissão estabeleceu como meta proceder a um estudo sobre o ensino secundário da Matemática em vários países, entre eles o Brasil, e sua constituição assinalava a existência de um primeiro movimento internacional para a modernização do ensino. As principais propostas desse movimento foram: promover a unificação dos conteúdos matemáticos abordados na escola em uma única disciplina, enfatizar as aplicações práticas da Matemática e introduzir o ensino do cálculo diferencial e integral no nível secundário.

Com uma série de decretos que se propunham a organizar nacionalmente a educação no país, em 1931, houve a reforma Francisco Campos. Nessa reforma, a proposta curricular da nova disciplina Matemática foi bastante detalhada, ultrapassando uma simples lista de conteúdos a serem ensinados na escola secundária. O texto iniciou-se por uma exposição das finalidades do ensino da Matemática, que tem por fim desenvolver a cultura espiritual do aluno pelo conhecimento dos processos matemáticos, habilitando-o, ao mesmo tempo, à concisão e ao rigor do raciocínio pela exposição clara do pensamento em linguagem precisa. 
É importante salientar que nas décadas de 40 e 50, o ensino da Matemática caracterizouse pela memorização e mecanização, também conhecido como "ensino tradicional". Com isso, se exigia do aluno que decorasse demonstrações de teoremas (memorização) e praticasse listas com enorme quantidade de exercícios (mecanização).

A partir da década de 1950 (em [6]), as disciplinas escolares, entre elas a Matemática, começaram a se modificar, pois modificou-se o público de estudantes, com a inserção, na educação escolar, de alunos provenientes das camadas populares, que vinham reivindicando há muito tempo o direito à escolarização. Tratava-se de uma democratização da escola, que passava a receber também os filhos da classe trabalhadora, e, assim, cresceu enormemente o número de alunos no primário e no secundário. As necessidades de professores para atender a esse público expandido levaram à diminuição das exigências na seleção desses profissionais.

De fato, o ensino da Matemática no Brasil se alterou muito a partir do final da década de 1950, quando tiveram início os primeiros congressos nacionais de ensino realizados no país. O primeiro desses encontros ocorreu em Salvador, em 1955, com a participação de 115 professores de sete estados, e o segundo, em Porto Alegre, em 1957, com a presença de 240 professores. Muitos matemáticos e professores de Matemática se envolveram, desde essa época, no movimento internacional que ficou conhecido como o Movimento da Matemática Moderna.

Em 1959, no $3^{\circ}$ Congresso Brasileiro de Ensino de Matemática, realizado no Rio de Janeiro, que agregou 500 professores de 18 estados, se verificaram as primeiras manifestações sobre o Movimento da Matemática Moderna no Brasil.

O Movimento da Matemática Moderna teve, como um de seus principais objetivos integrar os campos da Aritmética, da Álgebra e da Geometria no ensino, mediante a inserção de alguns elementos unificadores, tais como a linguagem dos conjuntos, as estruturas algébricas e o estudo das relações e funções. Enfatizou-se, ainda, a necessidade de conferir mais importância aos aspectos lógicos e estruturais da Matemática, em oposição às características pragmáticas que, naquele momento, predominavam no ensino, refletindo-se na apresentação de regras sem justificativa e na mecanização dos procedimentos. Como a Matemática havia se tornado, desde o século XIX, mais precisa e fundamentada logicamente, buscava-se que os conhecimentos veiculados na escola refletissem essa característica. Por outro lado, para a geometria, os defensores do movimento propuseram a substituição da abordagem clássica inspirada nos Elementos, de Euclides, que dominava as escolhas dos autores e professores há séculos, pelo enfoque das transformações geométricas, com o estudo dos conceitos de vetor, espaço vetorial e transformação linear.

A crítica à Matemática Moderna e a discussão sobre seu fracasso no ensino, no final 
da década de 1970 e início dos anos 1980, fizeram parte de um contexto de renovação dos ideais educacionais no país, estimulado pelo fim da ditadura militar. Em relação às propostas curriculares para a Matemática, no nível anteriormente chamado $1^{\circ}$ grau, surgiram alternativas ao ideário modernista, como a representada pelo documento oficial do estado de São Paulo, em 1986, que, centrada em três grandes temas, "números, medida e geometria", apresentava características opostas às prevalecentes durante a predominância das concepções associadas à Matemática Moderna. Entre essas alternativas destacaramse a preocupação com uma abordagem histórica dos temas, a ênfase na compreensão dos conceitos, levando-se em conta o desenvolvimento dos alunos, a acentuação na importância da geometria e a eliminação do destaque conferido aos conjuntos, à linguagem simbólica e ao rigor e à precisão na linguagem matemática. Ainda nos anos 80, buscou-se valorizar, na aprendizagem da Matemática, a compreensão da relevância de aspectos sociais, antropológicos, linguísticos, além dos cognitivos.

Outros marcos relevantes quanto ao ensino da Matemática no Brasil, nos últimos trinta anos do século XX, foram a implantação de programas de pós-graduação em Matemática nas universidades, desde 1971, e, a partir de 1987, a criação de cursos específicos de pósgraduação em Educação Matemática, em nível de especialização, mestrado e doutorado, em vários estados brasileiros. Salienta-se, ainda, a realização de inúmeros encontros locais, estaduais e nacionais de Educação Matemática e a fundação, em 1988, da Sociedade Brasileira de Educação Matemática "SBEM", uma sociedade civil, de caráter científico e cultural, cuja principal finalidade é congregar profissionais da área de Educação Matemática ou áreas afins. Os membros da SBEM são pesquisadores, professores e alunos que atuam na educação básica e superior no Brasil.

Nos anos 90, surgiu o que ficou conhecido como "ensino renovado", em face de se ter verificado que não era nas tarefas de cálculo que os alunos tinham os piores resultados, mas sim nas tarefas de ordem mais complexa, que exigiam algum raciocínio, flexibilidade e espírito crítico.

\subsection{Dificuldades de aprendizagem em Matemática}

Como visto anteriormente, a Matemática passou por muitas mudanças significativas durante esses mais de 500 anos no Brasil, porém, essas transformações não foram suficientes para tornar o ensino dessa disciplina eficaz e eficiente, pois, apesar de toda a luta para que a citada ciência exata viesse a ser uma matéria obrigatória e de fácil acesso a todas as pessoas, isto acabou tendo uma reação colateral um tanto quanto inesperada, pois fez com que ela virasse o martírio dos alunos nas escolas. Esse martírio é muito 
conhecido como a dificuldade em aprendê-la e ele não está ligado somente ao fato dessa matéria ser considerada, por muitos, complexa, mas pode estar na cultura do "não gostar" (pré-conceito) passado entre as gerações, em fatores mentais, psicológicos ou pedagógicos (falta de contextualização, linguagem, formação adequada de docentes).

Uma grande parte dos alunos apresenta baixo nível de proficiência em relação a essa disciplina (em [18]). Algumas avaliações são realizadas em âmbito nacional a fim de identificar o nível de proficiência dos alunos nesta área de conhecimento. Foi visto que o PISA avalia o desempenho dos alunos em Matemática, e na última edição, em 2012, o Brasil ficou na $58^{\mathrm{a}}$ posição, de 65 países. Segundo o Inep, o Brasil foi o país com maior avanço no desempenho de alunos de 15 anos em Matemática entre 2003 e 2012 no PISA. Apesar dessa melhoria acelerada no desempenho dos estudantes brasileiros em Matemática nesse período, 67,1\% dos alunos do país ainda estão abaixo da linha básica de proficiência, segundo o PISA 2012, ou seja, dois terços dos alunos são capazes de extrair, apenas, informações relevantes de uma única fonte e usar algoritmos, fórmulas, procedimentos e convenções básicas para resolver problemas envolvendo números inteiros.

A OCDE aponta que essa porcentagem está acima da média dos países-membros da entidade, mas que caiu em relação ao patamar de dez anos atrás, quando 75,2\% dos alunos brasileiros estavam nessa situação. Ainda de acordo com a avaliação, os alunos do país têm mais dificuldades em lidar com conteúdos ligados à álgebra e ao estudo de funções matemáticas, conforme Figura 1.6.

\begin{tabular}{|c|c|c|c|}
\hline Distrito Federal & 416 & Goiás & 379 \\
\hline Santa Catarina & 415 & Ceará & 378 \\
\hline Espírito Santo & 414 & Bahia & 373 \\
\hline Mato Grosso Do Sul & 408 & Mato Grosso & 366 \\
\hline Rio Grande Do Sul & 407 & Tocantins & 363 \\
\hline Sào Paulo & 404 & Pernambuco & 362 \\
\hline Paraná & 403 & Roraima & 360 \\
\hline Minas Gerais & 403 & Amapá & 360 \\
\hline Paraíba & 395 & Acre & 359 \\
\hline Rio De Janeiro & 389 & Amazonas & 343 \\
\hline Piauí & 385 & Maranhão & 342 \\
\hline Sergipe & 384 & Alagoas & \\
\hline Rondônia & 382 & &
\end{tabular}

Figura 1.6: Média em Matemática no PISA de 2012

Segundo o economista e politico Aloizio Mercadante, em entrevista coletiva em 3 de dezembro de 2013, (em [29] e [30]) 
A nossa fotografia ainda não é boa e não temos que nos acomodar com isso. Porém, o nosso filme é muito bom. Quando olhamos o filme, somos o primeiro da sala. (...) Uma das iniciativas relevantes que ajudam é a Olimpíada de Matemática. Isso mobiliza muito a rede, os gestores, gera muito autoestima e motivação dos estudantes. Esse é um dos instrumentos que ajudou decisivamente no salto de qualidade da década. (...) Partimos de patamar baixo, apesar de sermos o país que mais evoluiu, temos que ser rigorosos, se não nós não estaríamos tomando mais medidas para tentar melhorar o ensino médio, que é o maior desafio do ensino. (...) Levando em conta que nós somos um dos países que mais avançou em matemática e o país que mais avançou na média, é uma grande vitória. (...) E acho que avançou pelo esforço do estado brasileiro, pela dedicação dos professores, que condições adversas ensinando nossos estudantes, e pelo próprio empenho dos estudantes.

Surgem algumas perguntas: Por que o Brasil tem um desempenho tão ruim em Matemática? Aonde está o problema? No sistema de ensino? Na falta de interesse dos alunos? Na falta de capacitação dos docentes? Por que essa dificuldade tão grande em aprender Matemática?

Além dessas perguntas, existem tantas outras que não são fáceis de responder. Talvez não exista um motivo principal ou único para o baixo rendimento em Matemática, mas um conjunto de fatores. Considerando o aluno como um desses motivos, segundo Smith e Strick (em [19]), tem-se que a memória, a atenção, a atividade perceptivo-motora, a organização espacial, nas habilidades verbais, a falta de consciência, as falhas estratégicas são considerados os fatores responsáveis pelas diferenças na execução Matemática. Segundo Sanchez (em [15]), a linguagem e a terminologia utilizadas, que são precisas, exigem uma capacitação (nem sempre alcançada por certos alunos), não só do significado como da ordem e da estrutura em que se desenvolvem. Portanto segundo Markarian (em [9]), o aprendizado da Matemática, que depende muito de símbolos próprios e específicos, a tornam mais inacessível.

Sanchez (em [15]) ainda destaca que as dificuldades de aprendizagem em Matemática podem se manifestar nos seguintes aspectos:

Dificuldades em relação ao desenvolvimento cognitivo e à construção da experiência matemática; do tipo da conquista de noções básicas e princípios numéricos, da conquista da numeração, quanto à prática das operações básicas, quanto à mecânica ou quanto à compreensão do significado das operações. Dificuldades na resolução de problemas, o que implica a compreensão do problema, compreensão e habilidade para analisar o problema e raciocinar matematicamente. 
Dificuldades relativas à própria complexidade da matemática, como seu alto nível de abstração e generalização, a complexidade dos conceitos e algoritmos. A hierarquização dos conceitos matemáticos, o que implica ir assentando todos os passos antes de continuar, o que nem sempre é possível para muitos alunos; a natureza lógica e exata de seus processos, algo que fascinava os pitagóricos, dada sua harmonia e sua "necessidade", mas que se torna muito difícil pra certos alunos; a linguagem e a terminologia utilizadas, que são precisas, que exigem uma captação (nem sempre alcançada por certos alunos), não só do significado, como da ordem e da estrutura em que se desenvolve.

Dificuldades originadas no ensino inadequado ou insuficiente, seja porque à organização do mesmo não está bem sequenciado, ou não se proporcionam elementos de motivação suficientes; seja porque os conteúdos não se ajustam às necessidades e ao nível de desenvolvimento do aluno, ou não estão adequados ao nível de abstração, ou não se treinam as habilidades prévias; seja porque a metodologia é muito pouco motivadora e muito pouco eficaz. (p. 174)

Continuando a falar sobre os alunos, podemos colocar ainda como fatores a motivação e os pré-requisitos (ou a falta deles) que são peças chaves para uma boa aprendizagem em Matemática. Hengemüller (em [7], p.86) afirma que "A motivação humana é movida pelo sentido das coisas e pela necessidade. A motivação deve ir muito além da simples nota ao final de um período." E Tapia e Fita (em [20], p.51) afirmam que "um dos fatores contextuais que mais contribuem para definir a motivação dos alunos e facilitar ou dificultar a aprendizagem são as mensagens dadas pelo professor antes, durante e depois das tarefas escolares." E em relação aos pré-requisitos, Freire afirma (em [5]) que

Ninguém vai a lugar algum sem partir de onde está, toda aprendizagem a ser construída pelo aluno deve partir daquela que ele possui, isto é, para ensinar, é preciso partir do que ele conhece, o que também significa valorizar o passado do aprendiz, seu saber extra-escolar, sua cultura primeira adquirida antes da escola, enfim, sua experiência de vida.

Mudando um pouco o foco agora e analisando que a falta de capacitação ou despreparo dos docentes é um dos motivos do baixo rendimento em Matemática, Sanchez (em [15]) afirma que isso (o despreparo dos professores) pode gerar dificuldades relacionadas às adoções de posturas teórico-metodológicas ou insuficientes, seja porque a organização desses não está bem sequenciada, ou não se proporcionam elementos de motivação suficientes; seja porque os conteúdos não se ajustam às necessidades e ao nível de desenvolvimento do aluno, ou não estão adequados ao nível de abstração, ou não se treinam as habilidades prévias; seja porque a metodologia é pouco motivadora e pouco eficaz.

Além disso, os professores utilizam uma metodologia tradicional, com resolução excessiva de exercícios, sem aplicabilidade do conteúdo no dia a dia do aluno o que não motiva 
os alunos, fazendo com que eles não tenham interesse em aprender Matemática. Tiba (em [21], p. 64) afirma que:

Diante de uma matéria nova, o aluno toma consciência do que não sabia. Pode ou não optar por aprender. Escolhendo o aprendizado, ao passar a utilizar o novo saber, transforma seu conhecimento em sabedoria. Se não o puser em pratica, corre o risco de simplesmente esquecer o que aprendeu.

Ele afirma ainda, (em [21], p.63), "É inútil esperar que um aluno tome iniciativa própria por querer aprender algo que não lhe seja útil, porque seu cérebro ainda não amadureceu o suficiente. Por não saber aplicar o que aprendeu, surge a sensação de inutilidade do aprendizado."

Segundo a especialista argentina Patricia Sadovsky (em [31]), a má fama da Matemática se deve à abordagem superficial e mecânica realizada pela escola, pois falta formação aos docentes para aprofundar os aspectos mais relevantes, aqueles que possibilitam considerar os conhecimentos anteriores dos alunos, as situações didáticas e os novos saberes a construir. Ela afirma que a Matemática

é apresentada sem vínculos com os problemas que fazem sentido na vida das crianças e dos adolescentes. Os aspectos mais interessantes da disciplina, como resolver problemas, discutir ideias, checar informações e ser desafiado, são pouco explorados na escola. O ensino se resume a regras mecânicas que ninguém sabe, nem o professor, para que servem.

A pesquisadora defende, ainda, que é preciso aumentar a participação das crianças na produção do conhecimento, pois elas não suportam mais regras e técnicas que não fazem sentido.

\subsection{O papel do professor}

De acordo com os PCNs (em [2]), é de fundamental importância para o professor de Matemática:

a) identificar as principais características dessa ciência, de seus métodos, de suas ramificações e aplicações;

b) conhecer a história de vida dos alunos, seus conhecimentos informais sobre um dado assunto, suas condições sociológicas, psicológicas e culturais;

c) ter clareza de suas próprias concepções sobre a Matemática, uma vez que a prática em sala de aula, as escolhas pedagógicas, a definição de objetivos e conteúdos de ensino e as formas de avaliação estão intimamente ligadas a essas concepções. 
Assim, o papel do professor é de fundamental importância na formação do cidadão, pois cabe a ele colocar-se como ponte entre aluno e conhecimento. A busca ativa do conhecimento por um aluno está ligado, primordialmente, às decisões que o professor terá em sala de aula. Segundo Freire (em [5], p. 47), "Ensinar não é transferir conhecimento, mas criar as possibilidades para a sua produção ou construção." Afirma ainda na p.35 que "educar é substancialmente formar"

O papel do professor, hoje em dia, não é o de um mero transmissor do conteúdo, mas de um mediador que busca instigar seu aluno a participar ativamente e criticamente das aulas, considerando seus conhecimentos prévios e vivências e possibilitando momentos de reelaboração do saber dividido. Segundo D'Ambrósio (em [4], p. 73)

O professor que insistir no seu papel de fonte e transmissor de conhecimento está fadado a ser dispensado pelos alunos, pela escola e pela sociedade em geral. O novo papel do professor será o de gerenciar, de facilitar o processo de aprendizagem e, naturalmente, de interagir com o aluno na produção e na crítica de novos conhecimentos.

Existem diversas formas de o professor alcançar esses novos objetivos; ele não precisa ficar engessado as antigas tradições. Deve estar sempre se atualizando pedagogicamente, estudando, pesquisando, dedicando-se e buscando melhores formas de melhorar sua prática. Sobre isso Freire (em [5], p.40) afirma que "Na formação permanente dos professores, o momento fundamental é o da reflexão crítica sobre a prática. É pensando criticamente a prática de hoje ou de ontem que se pode melhorar a próxima prática." Para isso existem diversos cursos de aperfeiçoamento e de formação continuada para professores. Não há motivos para ficar estagnado no tempo.

Ser professor implica dedicar-se com amor e zelo à uma profissão que forma cidadãos capazes de reelaborar o conhecimento e de expressar uma compreensão da prática em termos tão elaborados quanto era possível ao educador. Freire (em [5]) confirma dizendo

Nas condições de verdadeira aprendizagem os educandos vão se transformando em reais sujeitos da construção e da reconstrução do saber ensinado, ao lado do educador, igualmente sujeito do processo. Só assim podemos falar realmente de saber ensinado, em que o objeto ensinado é apreendido na sua razão de ser e, portanto, aprendido pelos educandos.

E para concluir, D'Ambrósio (em [4], p. 63), afirma "O verdadeiro professor passa o que sabe não em troca de um salário, mas somente porque quer ensinar, quer mostrar os truques e os macetes que conhece".

Assim, ensinar é uma responsabilidade que precisa ser trabalhada e desenvolvida diariamente. O professor precisa sempre renovar sua forma pedagógica para atender a seus 
alunos da melhor maneira possível, pois é por meio do comprometimento e da paixão pela profissão que o educador pode assumir, verdadeiramente, o seu papel e se interessar em realmente aprender a ensinar. 




O ensino da história da Matemática não tem como intenção reproduzir os fatos históricos e, sim, basear-se neles para construção de uma sequência de ensino onde o conceito deixe de ser algo dogmático para se tornar mais compreensivo ao aluno, à medida que se associa ao mundo real. Segundo Vergnaud (em [23]) (1994, p.16 apud Lindegger):

É também o tipo de questão epistemológica que dirige a investigação do historiador quando ele tenta descobrir as circunstâncias históricas e sociais sob as quais as invenções matemáticas emergiram. Há muito o que ganhar a partir do estudo interativo do processo individual e histórico do desenvolvimento do conhecimento matemático. Mesmo que o conjunto de problemas que os estudantes proveitosamente venham a se deparar seja diferente do conjunto de problemas que os cientistas tenham encontrado no curso da história, é fundamental para a Psicologia da Educação Matemática considerar o relacionamento entre o conhecimento desses problemas.

E Schneider (em [17]) salienta que:

Cabe então descobrir novos jeitos de trabalhar com a Matemática, de modo que as pessoas percebam que pensamos matematicamente o tempo todo, resolvemos problemas durante vários momentos do dia e somos convidados a pensar de forma lógica cotidianamente. A Matemática, portanto, faz parte da vida e pode ser aprendida de uma maneira dinâmica e divertida.

De acordo com o dicionário eletrônico Houaiss, Trigonometria é uma parte da Matemática que estabelece os métodos de resolução dos triângulos e investiga as funções trigonométricas; o termo veio do latim científico, tendo sido criado em 1595 pelo matemático alemão Bartholomäus Pitiscus (1561-1613). Muitos livros didáticos utilizados em sala de aula dizem que a palavra Trigonometria deriva da união de três radicais gregos: tri (três)+ 
gonos (ângulos) + metron (medidas) e é a partir dessa união de radicais gregos que compreende-se o objetivo principal da trigonometria que é o de estudar medições em triângulos.

Teodolito é, segundo o dicionário eletrônico Houaiss, um instrumento de precisão para medir ângulos horizontais e ângulos verticais, muito empregado em trabalhos geodésicos e topográficos, conforme Figura 2.1. E de acordo com o MAST (em [32]) (Museu de Astronomia e ciências afins), é um instrumento ótico utilizado para medir ângulos, tanto horizontais como verticais, em medidas diretas e indiretas de distâncias.


Figura 2.1: Teodolito do século XIX e teodolito eletrônico

Para complementar o que se sabe sobre o teodolito é importante conhecer a história, pois pode proporcionar uma aproximação entre a Matemática e o meio social em que os alunos estão inseridos, acrescentando o aspecto vivo e dinâmico à abordagem teórica. Segundo D' Ambrósio (em [4] p. 30): “conhecer, historicamente, pontos altos da matemática de ontem poderá, (...) orientar no aprendizado e no desenvolvimento da matemática de hoje." Com base nisso, a seguir, apresenta-se um breve histórico da trigonometria e do teodolito.

\subsection{Breve histórico da Trigonometria}

Não se tem certeza da origem da trigonometria, mas sabe-se que o início do seu desenvolvimento se deu devido a problemas gerados pela Astronomia e Navegações, por volta do século IV ou V a.C., com os egípcios e babilônios. É possível encontrar problemas envolvendo cotangente no Papiro Rhind e uma notável tábua de secantes na tábula cuneiforme babilônica Plimpton 322, confrome Figura 2.2. 




Figura 2.2: Papiro Rhind

Por volta de 180 a 125 a.C., o astrônomo Hiparco de Nicéia (em [34]), conforme Figura 2.3, foi chamado de "o pai da trigonometria", pois, na segunda metade do século II a.C., fez um tratado em doze livros, em que se ocupou da construção do que deve ter sido a primeira tabela trigonométrica, isto é, uma tábua de cordas, com os valores dos seus arcos para uma série de ângulos, fazendo cálculos para usá-los em seus estudos de Astronomia. Usando os conhecimentos dos babilônicos, introduziu a divisão da circunferência em $360^{\circ}$ na Grécia.
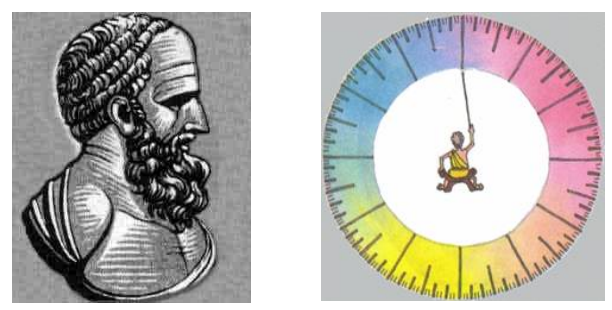

Figura 2.3: Hiparco de Nicéia e Divisão da circunferência em $360^{\circ}$

Originados pelos problemas relativos à Astronomia, surgiram os conceitos de seno e cosseno, enquanto que, ao que parece, o conceito de tangente surgiu da necessidade de calcular alturas e distâncias, como visto na Figura 2.4.



Figura 2.4: Exemplo do cálculo da altura

O nome seno, do latim sinus (que significa seio, volta, curva, cavidade), mas, na verdade, é a tradução latina da palavra árabe jaib, que significa dobra, bolso ou prega de uma vestimenta que não tem nada a ver com o conceito matemático de seno. Trata-se de uma tradução defeituosa que dura até hoje. Atualmente, seno é a razão entre o cateto 
oposto (CO) e a hipotenusa (HIP) de um triângulo retângulo:

$$
\operatorname{sen}(x)=\frac{\mathrm{CO}}{\mathrm{HIP}}
$$

A palavra cosseno surgiu somente no século XVII, como sendo o seno de um ângulo complementar. Hoje cosseno é a razão entre o cateto adjacente (CA) e a hipotenusa (HIP) de um triângulo retângulo:

$$
\cos (x)=\frac{\mathrm{CA}}{\mathrm{HIP}}
$$

Por sua vez, a função tangente era a antiga função sombra, que tinha ideias associadas às sombras projetadas por uma vara colocada na horizontal. A variação na elevação do Sol causava uma variação no ângulo que os raios solares formavam com a vara e, portanto, modificava o tamanho da sombra. Hoje a tangente é a razão entre o cateto oposto (CO) e o cateto adjacente $(\mathrm{CA})$ de um triângulo retângulo:

$$
\operatorname{tg}(x)=\frac{\mathrm{CO}}{\mathrm{CA}}
$$

\subsection{Breve histórico do Teodolito}

O primeiro teodolito contendo quatro parafusos niveladores foi construído por Jonathan Sisson, em 1720. Mas, em 1835, Ignácio Porro, inventor de instrumentos ópticos, contribuiu com o aprimoramento do teodolito acoplando o telescópio. Ao longo dos anos, o teodolito foi sendo transformado e a ele agregados sistemas e mecanismos que o tornaram mais preciso em suas medições.

Em geral, junto do teodolito é usada uma bússola para medir os ângulos formados pela posição no terreno em que está sendo realizado o levantamento topográfico/geodésico, com a direção do meridiano magnético.

Alguns teodolitos antigos possuíam a bússola acoplada em sua estrutura, como é o caso do teodolito trânsito, conforme na Figura 2.5.



Figura 2.5: Teodolito trânsito 
Nas explorações do território brasileiro e demarcação de limites, o teodolito foi muito utilizado na demarcação do Planalto Central do Brasil, em 1892, e pela Comissão de Limites entre Brasil e Bolívia.

O teodolito repetidor selecionado para compor o multimídia para a exposição de longa duração do museu do MAST foi doado ao Observatório Nacional em 1862 pelo Conde Prados e hoje faz parte do acervo do museu.

Este instrumento foi utilizado pela Comissão de Pernambuco durante a Observação da Passagem de Vênus pelo disco solar, em 1882, e participou da Exposição Internacional do Centenário da Independência do Brasil, em 1922, realizada no Palácio dos Estados, no Rio de Janeiro.

Atualmente, tem-se o teodolito eletrônico que é mais leve e fácil para transportar, além de ser capaz de realizar medições com maior precisão e possuir um dispositivo com ótica de alto rendimento e facilidade de utilização. Além disso, a ele podem ser acoplados outros equipamentos de medição como o distanciômetro eletrônico ou trena eletrônica, como na Figura 2.6.



Figura 2.6: Teodolito eletrônico

A estação total é um outro tipo de equipamento moderno utilizado na medida de ângulos e distâncias. Esse instrumento é uma junção do teodolito eletrônico digital com o distanciômetro eletrônico.

As estações totais são usadas em qualquer tipo de levantamento topográfico ou geodésico. Alguns modelos de estação total são robotizados e é o operador quem segura o prisma refletor e controla a máquina via controle remoto, a partir do ponto observado. Esse tipo de equipamento é usado principalmente em trabalhos de monitoramento de obras, medição de deformações e deslocamentos de terras, como na Figura 2.7. 



Figura 2.7: Estação total

\subsection{Trigonometria nas escolas}

No início do século XX, alguns livros abordavam a trigonometria elementar e noções de trigonometria esférica, assim como se verifica no livro adotado, Trigonometria Elementar da editora FTD, em 1928, pelo Colégio Pedro II. A proposta do livro era o tratamento da trigonometria como conteúdo isolado dos demais segmentos matemáticos e das demais áreas, não havendo uma preocupação com o desenvolvimento conceitual das noções básicas da trigonometria. Assim, a trigonometria não era relacionada com os fatos históricos do desenvolvimento da Matemática, como por exemplo o surgimento da trigonometria com os esticadores de cordas e a origem da nomenclatura utilizada (seno, cosseno e tangente), o que poderia facilitar a compreensão do aluno com relação às aplicações desse conteúdo no desenvolvimento das civilizações.

Com o passar dos anos, pouco se mudou no ensino da trigonometria e os livros não traziam uma abordagem histórica que auxiliasse na construção do conhecimento desse conteúdo. Somente em 1963, Ary Quintella apresentou um livro didático com aspectos históricos do desenvolvimento dos conceitos trigonométricos sendo utilizados na apresentação dos tópicos trigonométricos presentes no livro (em [11]).

Nos livros atuais, a maioria apresenta somente referências bibliográficas de alguns matemáticos famosos e algumas informações sobre o desenvolvimento cronológico da matemática abordada.

Hoje, a trigonometria faz parte do currículo escolar do $9^{\circ}$ ano do Ensino Fundamental e do $1^{\circ}, 2^{\circ}$ e $3^{\circ}$ anos do Ensino Médio. Segundo os Parâmetros Curriculares do Ensino Médio (em [1]):

Outro tema que exemplifica a relação da aprendizagem de Matemática com o desenvolvimento de habilidades e competências é a trigonometria, desde que seu estudo esteja ligado às aplicações, evitando-se o investimento excessivo no cálculo algébrico das identidades e equações análise de seus gráficos. Especialmente para o indivíduo que não prosseguirá seus estudos nas carreiras ditas exatas, o que deve ser assegurado 
são as aplicações da trigonometria na resolução de problemas que envolvem medições, em especial o cálculo de distâncias inacessíveis, e na construção de modelos que correspondem a fenômenos periódicos.

Assim, o ensino da trigonometria ligado às aplicações e contextualizações históricas deve estimular o interesse, a curiosidade, a investigação e o desenvolvimento da capacidade de resolver problemas dos alunos.

\subsection{Trigonometria e a Pedagogia}

É importante diversificar os meios e métodos no processo ensino e aprendizagem que motivem e estimulem a construção do conhecimento matemático, permitindo ao aluno construir os conceitos e as abstrações necessárias para o entendimento dos conteúdos trigonométricos abordados, evitando a memorização de conceitos e fórmulas estudados. D'Ambrósio (em [3], p. 25) enfatiza que: "a adoção de uma forma de ensino mais dinâmica, mais realista e menos formal, mesmo no esquema de disciplinas tradicionais, permitirá atingir objetivos mais adequados à nossa realidade".

O uso da contextualização histórica como recurso didático também é contemplado nos PCNs (em [2]), propondo sua utilização no processo de aprendizagem:

A História da Matemática pode oferecer uma importante contribuição no processo de ensino e aprendizagem dessa área de conhecimento. Ao revelar a Matemática como uma criação humana, ao mostrar as necessidades e preocupações de diferentes culturas, em diferentes momentos históricos, ao estabelecer comparações entre os conceitos e processos matemáticos do passado e do presente, o professor cria condições para que o aluno desenvolva atitudes e valores mais favoráveis diante desse conhecimento.

Diante disso, a articulação do estudo da Trigonometria com sua contextualização histórica aliada à construção do teodolito pode trazer bons resultados no processo de ensino aprendizagem. 




Esse capítulo tem por finalidade apresentar detalhadamente o caminho utilizado para a realização do projeto, especificando os procedimentos necessários para se chegar aos participantes, obter as informações de interesse e analisá-las. O método utilizado foi o exploratório, onde foram esmiuçados os conhecimentos adquiridos ao longo dos anos pelos discentes, visando verificar se eles lembravam de conteúdos de anos anteriores, aprendizados esses que eram necessários para a realização do presente trabalho. Contempla ainda a exploração de pesquisa realizada em campo (in loco), bem como a escolha do local, a realização das atividades de sondagem, a contextualização e procedimentos de análise de dados colhidos.

\subsection{O projeto}

O presente projeto pretende verificar a viabilidade do ensino da Matemática/Trigonometria através de aulas contextualizadas com o histórico de cada conteúdo a ser trabalhado em sala de aula e o uso da ferramenta de construção do teodolito, instrumento utilizado para trabalhar com trigonometria.

Para isso foi feita uma vasta pesquisa bibliográfica para escolher os melhores caminhos a seguir, assim como afirma Ander-Egg (em [8], p. 155) em que pesquisa "é um procedimento reflexivo sistemático controlado e crítico, que permite descobrir fatos ou dados, relações ou leis, em qualquer campo do conhecimento", a fim de dar um suporte ao que foi planejado, realizando primeiro o mais importante. Assim, verificou-se que seria necessário fazer algumas atividades em que as primeiras questões eram de sondagem, para analisar o que o aluno sabia ou não sobre os conteúdos trabalhados, para, depois, sanar 
as dúvidas apresentadas por eles, a partir de várias intervenções, fossem elas: explicações no quadro, trabalhos em grupo ou com monitoria (onde os próprios discentes ajudavam os demais) ou explicações individuais. Além disso, foi feito um apanhado histórico sobre cada conteúdo apresentado aos alunos que se surpreenderam com as histórias, pois eles as desconheciam, o que fez aguçar o interesse em particular de cada um deles. O resultado disso foi exposto de diversas formas pelos alunos, que, de forma verbal e escrita, expressaram que gostaram bastante de saber a respeito dessa contextualização (de onde, como e quando a Matemática surgiu), porque eles tinham grande curiosidade de conhecer esse histórico. Também foi dada aplicabilidade das atividades ao cotidiano habitual para mostrar aos alunos que a matemática é sempre importante e necessária.

Para finalizar, houve um momento de socialização de opiniões, momento o qual, os alunos puderam debater sobre o que mais gostaram no projeto e responderam à pesquisa de opinião.

\subsection{O local}

Atualmente, segundo dados do censo escolar de 2013 (em [35]), há 664 escolas públicas e aproximadamente 160 escolas privadas no Distrito Federal. No início de 2015, 320 escolas públicas passaram por pequenos reparos antes das aulas, um gasto de $\mathrm{R} \$ 3,5$ milhões, segundo o governo do Distrito Federal. O GDF informou também que está concluindo um plano de obras junto com as 14 regionais de ensino e, quando tiver dinheiro em caixa, vai começar os processos de licitação para as grandes reformas nas escolas.

Um relatório do Tribunal de Contas da União (TCU) divulgado no final de 2014 apresentou o diagnóstico da educação no Distrito Federal. O estudo, que avaliou as instalações físicas das escolas públicas e os problemas relacionados à manutenção e reforma, mostrou que $44 \%$ das escolas precisavan de pequenos reparos, $31 \%$ estavam em condições ruins e $6 \%$ estavam em péssimas condições, a maioria delas no campo.

Acerca dessas informações, foi escolhida uma escola de Ensino Fundamental aleatoriamente no Distrito Federal que tivesse turmas de $9^{\circ}$ anos para aplicação do projeto.

A escola escolhida norteia-se pelos princípios e fins da Educação estabelecidos na Lei de Diretrizes e Bases da Educação Nacional, respeitando a legislação correlata vigente e superveniente, visando o pleno desenvolvimento do educando, seu preparo para o exercício da cidadania e a sua preparação geral para o mundo do trabalho.

Ressalta-se que a escola escolhida autorizou a realização e publicação do projeto, desde que a imagem de nenhum aluno fosse divulgada. 


\subsection{Os participantes}

O público alvo do projeto foram os estudantes do $9^{\circ}$ ano do Ensino Fundamental, uma vez que a Trigonometria faz parte do conteúdo programático para essa série e eles têm a maturidade, a habilidade e a disponibilidade necessárias para a realização do projeto.

No ano de 2015, o $9^{\circ}$ ano da escola escolhida contava com 4 turmas dessa série, cada uma com, aproximadamente, 30 (trinta) alunos, sendo que uma delas era no período vespertino e as demais, no matutino. Foi sorteada uma das turmas para participar do projeto, pois muitos alunos queriam participar e era inviável atender a todos. Segundo Mattar (em [10], p.123),

A amostragem está baseada em duas premissas. A primeira é a de que há similaridade entre os elementos de uma população, de tal forma que uns poucos elementos representarão adequadamente as características de toda a população; a segunda é a de que a discrepância entre os valores das variáveis na população e os valores dessas variáveis obtidos na amostra são minimizados, pois enquanto algumas medições subestimam o valor do parâmetro, outras superestimam e, desde que a amostra tenha sido adequadamente obtida, as variações nestes valores tendem a contrabalançarem-se e a anularam-se umas às outras, resultando em medidas na amostra que são, geralmente, próximas às medidas da população.

Todos os integrantes da turma sorteada preencheram um termo de voluntariado e, pelo fato de serem menores de idade, esses mesmos termos foram assinados pelos seus respectivos pais e/ou responsáveis.

\subsection{Atividades Desenvolvidas}

As atividades do presente projeto (ver Apêndice A) foram desenvolvidas no $1^{\circ}$ semestre letivo do ano de 2015, no período de 02 de fevereiro a 25 de junho. Ocorreram durante as aulas de Matemática, sem que houvesse prejuízo nos conteúdos previstos nem no planejamento dos professores de Matemática para a sala de aula, na turma sorteada. Por esse motivo, as atividades não eram desenvolvidas em datas pré-estabelecidas, mas foram viáveis para a realização e coleta de dados da pesquisa. Todavia, a presente disponibilidade aleatória de datas não atrapalhou a concretização e realização do projeto programado.

Cabe ressaltar que alguns conteúdos abordados no projeto são previstos para serem trabalhados no $2^{\circ}$ semestre do ano letivo, ou seja, durante o andamento do projeto os alunos ainda não tinham tido contato com os conteúdos nas aulas de Matemática do currículo normal escolar. Em compensação, outros conteúdos já haviam sido trabalhados em anos anteriores servindo como base e pré-requisitos para a realização do projeto. 
Além disso, é importante salientar que não foi feita uma avaliação diagnóstica separada, mas que todas as atividades vinham com as primeiras questões como atividades de sondagem, tendo como sequência a explanação dos conteúdos e realização/resolução de questões mais complexas e, por fim, uma abordagem histórica do assunto trabalhado.

Cada atividade foi entregue aos alunos que respondiam, inicialmente, somente as questões de sondagem. Após o término, eles comparavam suas resoluções com os colegas e depois havia a correção e explicação por parte da professora no quadro. Em seguida, os alunos respondiam as demais questões, entregavam as atividades para a professora que as corrigia em casa e devolvia posteriormente para passar o feedback aos alunos dos erros e acertos.

\subsubsection{Atividade 1: Raiz quadrada}

A primeira atividade teve por objetivo revisar e aprimorar o conceito de raiz quadrada. Vale ressaltar que os alunos só tinham o conhecimento prévio do cálculo da raiz quadrada exata de números reais, pois o cálculo de raiz aproximada ou simplificação de radicais seria um conteúdo ensinado algumas semanas depois. Dessa forma, as três primeiras questões de sondagem foram realizadas para fazer um levantamento prévio dos conhecimentos que os alunos tinham desse conteúdo. Na sequência tinham mais três questões sobre simplificação de radicais (conteúdo programático do $9^{\circ}$ ). Essa atividade contava com questões discursivas abrangendo os conhecimentos da disciplina de Matemática: fatoração, números reais, raiz quadrada.

\subsubsection{Atividade 2: Média Aritmética}

Nessa atividade, que tinha como objetivo revisar esse conceito tão importante e conhecido dos alunos, foi feita, primeiramente, a abordagem histórica sobre o assunto, depois as questões de sondagem, na sequência a explanação do conteúdo para que os alunos recordassem do assunto. Essa atividade contava com questões objetivas e discursivas abrangendo os conhecimentos da disciplina de Matemática: adição, divisão, interpretação e média aritmética.

\subsubsection{Atividade 3: Dízima periódica}

Essa atividade teve como objetivo revisar a transformação de uma dízima periódica simples ou composta em fração geratriz, que foi um conteúdo trabalhado no ano anterior. A abordagem histórica motivou os alunos a relembrarem o conteúdo e a atividade con- 
tava com questões discursivas abrangendo conhecimentos da disciplina de Matemática: resolução de equações e fração geratriz.

\subsubsection{Atividade 4: Medidas de comprimento}

Nessa atividade, os alunos puderam relembrar as transformações das medidas de comprimento de fundamental importância para o projeto e para as novas disciplinas física e química (do currículo do $9^{\circ}$ ano). A abordagem histórica fez com que os alunos começassem a ter um novo olhar para a Matemática e conhecessem outros tipos de medidas de comprimento, como a polegada (que eles sempre ouviram quando se falava de televisão).

\subsubsection{Atividade 5: Regra de três simples}

Essa atividade teve como objetivo revisar o cálculo de regra de três diretamente e inversamente proporcionais, pois para a concretização do projeto os alunos precisariam desse conceito.

\subsubsection{Atividade 6: Teorema de Pitágoras}

Essa atividade foi sobre um assunto novo para os alunos, uma vez que somente seria ensinado no $2^{\circ}$ semestre, mas como é um teorema muito conhecido, os alunos já tinham ouvido falar sobre ele, apesar de não terem visto aplicações do assunto. Foi feita a demonstração do teorema a partir de áreas de quadrados no quadro para os alunos e em seguida foi feita a contextualização histórica. Essa atividade contava com questões objetivas e discursivas abrangendo os conhecimentos da disciplina de Matemática: triângulos, áreas e Teorema de Pitágoras.

\subsubsection{Atividade 7: Ângulo e Transferidor}

Essa atividade teve como objetivo inserir instrumentos matemáticos na sala de aula, uma vez que nem sempre os alunos têm essa oportunidade. Com atividades de construção de ângulos a partir de um transferidor e da medição da medida deles, os alunos puderam se familiarizar e entender melhor o conceito de ângulos. Com a contextualização e as aplicações os alunos se sentiram motivados a realizar a atividade. Essa atividade contava com questões objetivas discursivas abrangendo os conhecimentos da disciplina de Matemática: ângulos (medida, classificação, construção) e uso do transferidor. 


\subsubsection{Atividade 8: Compasso}

Mais uma atividade com o objetivo de inserir instrumentos matemáticos na sala de aula, com o uso de régua e compasso, no qual os alunos tiveram a oportunidade de conhecer construções geométricas utilizando esses instrumentos e conhecer um pouco mais da história da geometria.

\subsubsection{Atividade 9: Trigonometria}

Para encerrar as atividades teóricas, foi feita a abordagem histórica da trigonometria juntamente com a explanação do conteúdo, mostrando as razões trigonométricas e a tabela com os ângulos notáveis. Com imensa aplicabilidade no dia a dia, os alunos realizaram as atividades propostas utilizando trigonometria e também o Teorema de Pitágoras.

\subsubsection{Atividade 10: Construção do Teodolito e aplicação dos con- ceitos de Trigonometria}

Nessa atividade os alunos foram levados para o ambiente fora da sala de aula. Mas antes de saírem da escola, os alunos mediram sua altura e quantos passos cabiam em um metro para poderem fazer a regra de três e determinar a distância em metros até os edifícios selecionados. Com o material separado, cada aluno construiu seu próprio teodolito seguindo as instruções dadas e três prédios foram escolhidos para que fosse determinado suas alturas. Primeiramente os alunos visualizaram o topo do prédio com o teodolito e anotaram o ângulo de visualização. Em seguida mediram a distância até o prédio, em passos, a partir do ponto de visualização escolhido. Esse procedimento foi feito para cada prédio. E para finalizar, os alunos voltaram para a sala de aula para poderem calcular a altura de cada prédio utilizando a tabela trigonométrica dada, os dados coletados e a tangente dos ângulos visualizados.

\subsubsection{Atividade 11: Pesquisa de opinião}

Como última atividade, para integração dos alunos, foi feito um debate em sala onde os alunos puderam partilhar as experiências adquiridas durante a realização do projeto e suas perspectivas para as próximas aulas de Matemática. Foi solicitado que cada um preenchesse uma pesquisa de opinião, colocando suas impressões. 




Este capítulo visa detalhar os resultados obtidos em cada uma das atividades realizadas no projeto, bem como avaliar os conhecimentos adquiridos, tendo como parâmetros as questões de sondagem em cada atividade e o desempenho dos alunos nas avaliações regulares da escola. Nesta parte do trabalho, também estão explicitadas as impressões dos alunos, obtidas por ocasião da pesquisa de opinião, realizada ao término do projeto.

\subsection{Análise Quantitativa das Atividades}

Foi feita a análise dos resultados obtidos em cada atividade, levando em consideração os acertos e os erros dos alunos. Dessa forma, em cada questão é feito um gráfico para verificar o aprendizado ou não das questões.

\subsubsection{Atividade 1: Raiz quadrada}

Apesar de a maioria da turma sorteada estar empolgada com a participação do projeto, os alunos não pareceram tão motivados quando lhes foi entregue a primeira atividade, principalmente quando lhes foi passado o histórico sobre o assunto. Mesmo com uma longa conversa de conscientização com os participantes sobre a importância da realização com seriedade do projeto, nessa atividade muitos alunos não tiveram o devido cuidado ao responder as questões propostas. Nas atividades de sondagem, que eram questões introdutórias sobre raiz quadrada, os alunos tiveram um bom desempenho. A maioria acertou as duas questões propostas como se pode verificar nos gráficos a seguir: 


\begin{tabular}{|l|l|}
\hline Questão 1 & Você sabe calcular a raiz quadrada de um número real? \\
\hline Questão 2 & Qual é o valor de $\sqrt{4} ?$ \\
\hline Questão 3 & Por que não tem sentido calcular $\sqrt{-4}$ no conjunto dos números reais? \\
\hline
\end{tabular}


Figura 4.1: Questões 1, 2 e 3

Porém, o mesmo não se pode dizer em relação as questões após a explanação do conteúdo, pois o desempenho dos alunos ficou aquém do esperado, uma vez que os alunos não julgavam importante responder questões que não valiam pontos na média da escola. Vale ressaltar que, quando essa atividade foi passada em sala de aula, os alunos ainda não haviam visto o conteúdo no currículo regular.

\begin{tabular}{|l|l|}
\hline Questão 4 & Qual a raiz quadrada de $0,09 ?$ E de $1,44 ?$ \\
\hline Questão 5 & Qual a raiz quadrada de $32 ?$ E de $512 ?$ \\
\hline Questão 6 & Qual é o valor de $\sqrt{\frac{8}{36}} ?$ \\
\hline
\end{tabular}


Figura 4.2: Questões 4, 5 e 6

\subsubsection{Atividade 2: Média Aritmética}

Esse não era um conteúdo programático para o $9^{\circ}$ ano, porém, por ser um assunto do cotidiano dos alunos, foi feita a abordagem histórica e uma retomada desse conteúdo 
que tem várias aplicações em Matemática, Física e Química. Nas primeiras questões, que eram de sondagem, percebe-se que os alunos não tinham o conhecimento prévio necessário para a realização da atividade, pois não apresentaram um resultado satisfatório.

\begin{tabular}{|l|l|}
\hline Questão 1 & Você sabe calcular a média aritmética entre dois ou mais números? \\
\hline Questão 2 & $\begin{array}{l}\text { Um grupo de pessoas apresenta as idades de 10, 13, } 15 \text { e } 17 \text { anos. Se uma } \\
\text { pessoa de } 12 \text { anos se juntar ao grupo, o que acontecerá com a média de } \\
\text { idade do grupo? }\end{array}$ \\
\hline Questão 3 & $\begin{array}{l}\text { Um aluno tirou as notas } 5,7,9 \text { e } 10 \text { em quatro provas. Qual será a sua } \\
\text { média no final do bimestre, sabendo que a média utilizada será a } \\
\text { aritmética? }\end{array}$ \\
\hline Questão 4 & $\begin{array}{l}\text { Ao pesquisar o preço de um determinado produto em } 20 \text { postos de vendas, } \\
\text { encontraram-se } 3 \text { preços diferentes, sendo a distribuição representada em } \\
\text { um gráfico. Considerando esses } 20 \text { postos de vendas, o preço médio do } \\
\text { produto é igual a: }\end{array}$ \\
\hline
\end{tabular}
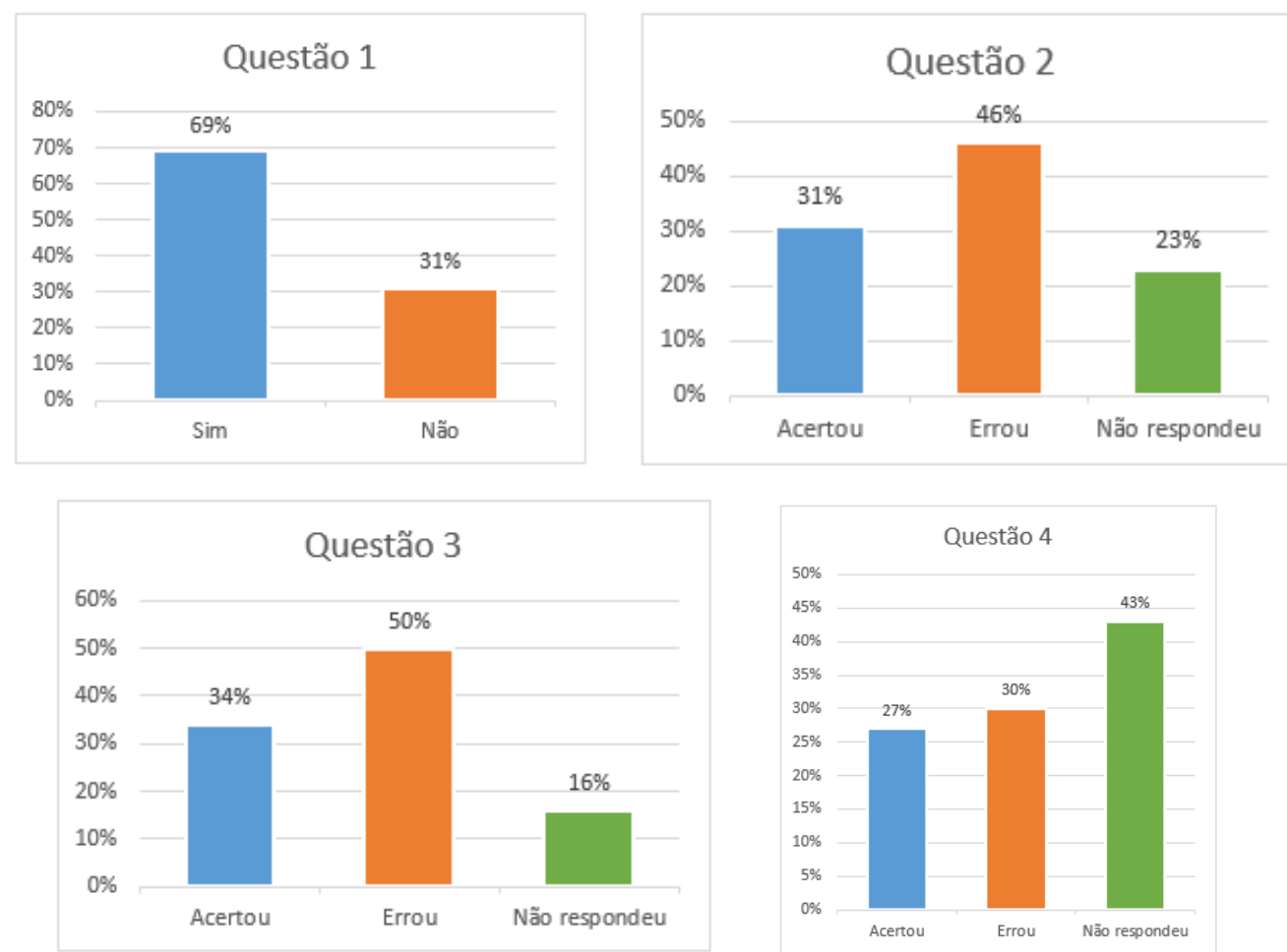

Figura 4.3: Questões 1, 2, 3 e 4

Após os alunos verificarem seus erros com a correção das questões de sondagem, percebe-se uma melhoria significativa na resolução da Questão 5, uma vez que a maioria 
dos discentes acertaram essa questão. O mesmo já não se pode dizer da Questão 6, pois os alunos não tiveram um bom rendimento se comparada com a Questão 4 (de igual nível de dificuldade). Para essa questão, percebe-se uma melhora somente na tentativa de tentar responde-la, pois, mesmo errando, os alunos pelo menos tentaram fazer os cálculos.

\begin{tabular}{|l|l|}
\hline Questão 5 & $\begin{array}{l}\text { O dólar é considerado uma moeda de troca internacional, por } \\
\text { isso o seu valor diário possui variações. Acompanhando a variação de } \\
\text { preços do dólar em reais durante uma semana verificou-se as variações } \\
\text { de acordo com a tabela informativa. Determine o valor médio do preço } \\
\text { do dólar nesta semana? }\end{array}$ \\
\hline Questão 6 & $\begin{array}{l}\text { Uma pessoa comprou } 5 \text { garrafas de suco de frutas, uma de cada tipo. } \\
\text { A tabela mostra o preço de cada garrafa de suco. Sabendo que nessa } \\
\text { compra o preço médio de uma garrafa foi } \mathrm{R} \$ 3,80 \text {, pode-se concluir que } \\
\text { o preço da garrafa de suco de uva é: }\end{array}$ \\
\hline
\end{tabular}
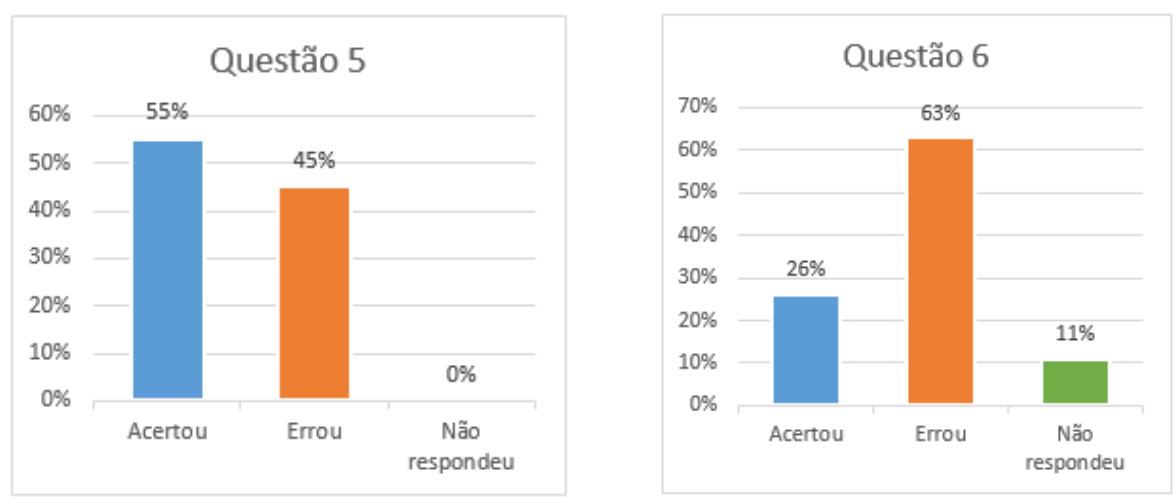

Figura 4.4: Questões 5 e 6

\subsubsection{Atividade 3: Dízima Periódica}

Essa atividade foi sobre um conteúdo aprendido no $8^{\circ}$ ano. Os alunos que estudaram na escola no ano anterior disseram que conheciam o conteúdo, enquanto os alunos novos disseram que o desconheciam. Pela análise dos gráficos, percebe-se que os alunos tiveram uma maior dificuldade para responder a questão de dízima periódica composta.

\begin{tabular}{|l|l|}
\hline Questão 1 & Você sabe o que é a geratriz de uma dízima periódica? \\
\hline Questão 2 & Você sabe transformar uma dízima periódica em fração? \\
\hline Questão 3 & Transforme a dízima periódica $0,555 \ldots$ em uma fração irredutível. \\
\hline Questão 4 & Transforme a dízima periódica $2,1333 \ldots$ em uma fração irredutível. \\
\hline
\end{tabular}





Figura 4.5: Questões 1, 2, 3 e 4

Após a realização das primeiras questões pelos alunos, essas questões foram corrigidas no quadro e houve uma explanação sobre o conteúdo. Logo após, os alunos resolveram as demais questões. Percebe-se uma melhora significativa na resolução dessas atividades por parte dos alunos, principalmente na dízima periódica composta, pois todos os estudantes tentaram responder e a maioria da turma acertou.

\begin{tabular}{|l|l|}
\hline Questão 5 & Transforme a dízima periódica $0,1212 \ldots$ em uma fração irredutível. \\
\hline Questão 6 & Transforme a dízima periódica $0,0222 \ldots$ em uma fração irredutível. \\
\hline
\end{tabular}
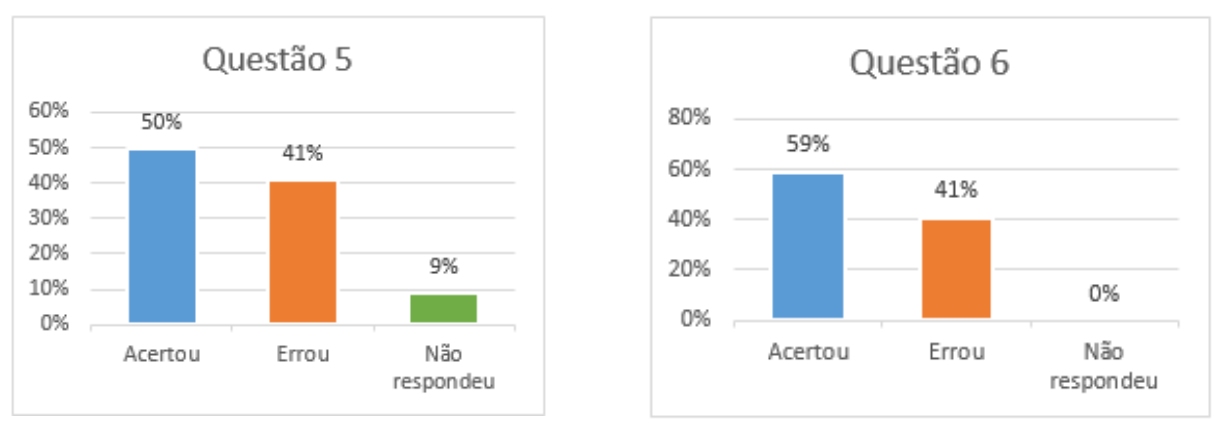

Figura 4.6: Questões 1 e 2 


\subsubsection{Atividade 4: Medidas de comprimento}

Esse não era um conteúdo programático para o $9^{\circ}$ ano, mas os alunos necessitavam desse conteúdo para trabalhar com áreas, perímetros, conversão de unidades, principalmente nas áreas de Matemática, Física e Química. Nessa atividade os alunos responderam a todas as questões, relatando que essa era a atividade mais fácil e, provavelmente, por conta disso tiveram alguns deslizes na resolução de algumas questões, conforme podemos ver nos gráficos a seguir.

\begin{tabular}{|l|l|}
\hline Questão 1 & Você conhece alguma medida de comprimento? Quais? \\
\hline Questão 2 & $\begin{array}{l}\text { Qual a melhor medida de comprimento para medir o tamanho } \\
\text { da sua caneta? E para medir a altura de um prédio? }\end{array}$ \\
\hline Questão 3 & Você sabe fazer a conversão das unidades de medidas de comprimento? \\
\hline Questão 4 & $\begin{array}{l}\text { A distância de sua casa até a escola é de } 2,5 \mathrm{~km} \text {. Converta essa medida } \\
\text { em metro }(\mathrm{m}) .\end{array}$ \\
\hline
\end{tabular}
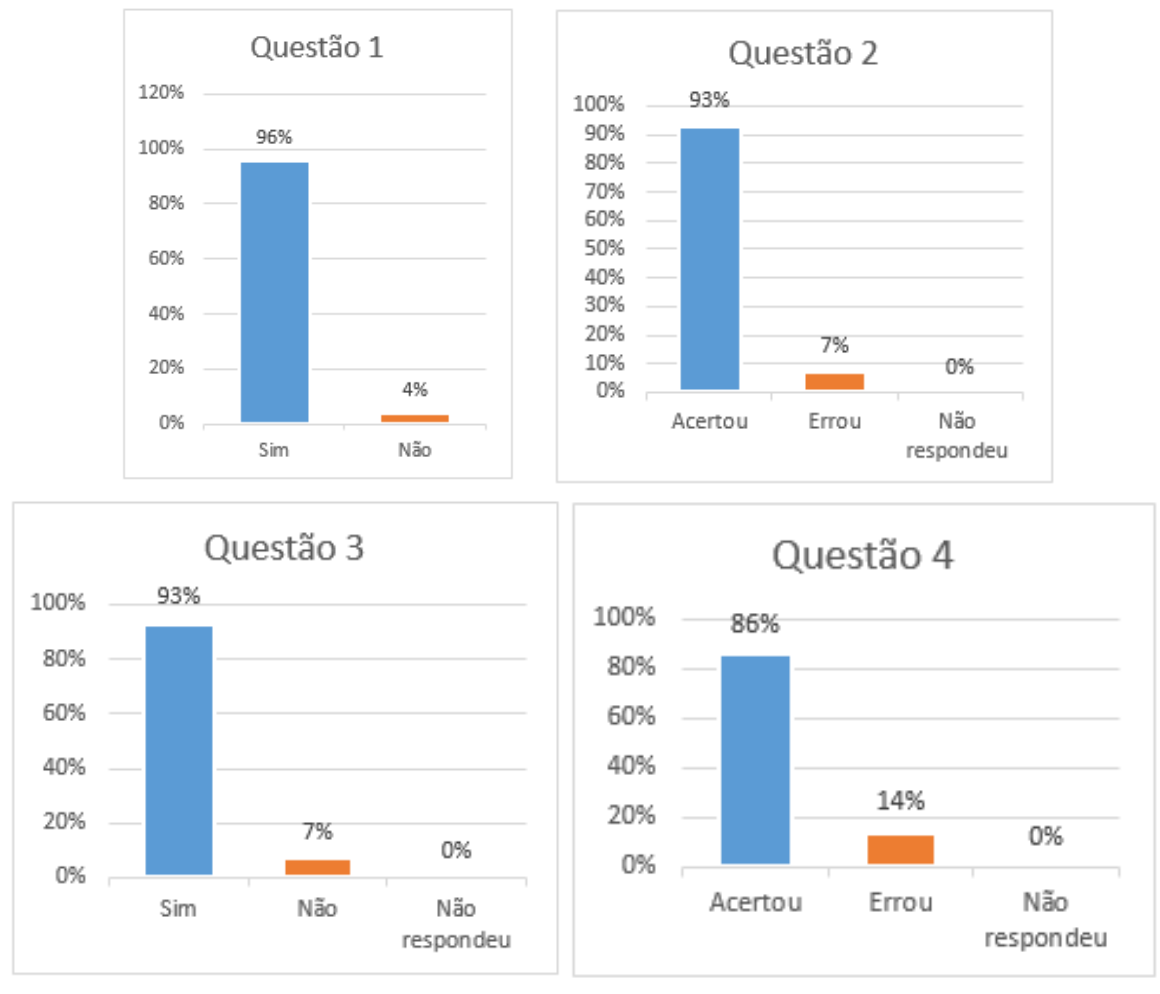

Figura 4.7: Questões 1, 2, 3 e 4

Os alunos apresentaram um melhor rendimento nas primeiras questões. Os erros em geral eram de décimos. Faltou um pouco de atenção e cuidado por parte dos alunos na resolução dessa atividade. 


\begin{tabular}{|l|l|}
\hline Questão 5 & Converta 15 metros em quilômetros $(\mathrm{km})$. \\
\hline Questão 6 & Converta 23,45 dm em hm. \\
\hline Questão 7 & Converta 0,1234 dam em mm. \\
\hline
\end{tabular}



Figura 4.8: Questões 5, 6 e 7

\subsubsection{Atividade 5: Regra de três simples}

Esse conteúdo foi visto somente no $7^{\circ}$ ano, mas é de fundamental importância para a resolução de diversos problemas em Matemática, Física e Química. E para a atividade de construção do teodolito esse conteúdo será utilizado para a conversão dos passos em metros. Nota-se que os alunos apresentaram bastante dificuldade na resolução desses exercícios, principalmente na regra de três inversamente proporcional, pois deixaram as primeiras questões sem responder (um grande índice dos alunos).

\begin{tabular}{|l|l|}
\hline Questão 1 & Você sabe utilizar a regra de três simples? \\
\hline Questão 2 & $\begin{array}{l}\text { Um muro de } 12 \text { metros foi construído utilizando } 2160 \text { tijolos. } \\
\text { Caso queira construir um muro de } 30 \text { metros nas mesmas condições } \\
\text { do anterior, quantos tijolos serão necessários? }\end{array}$ \\
\hline Questão 3 & $\begin{array}{l}\text { Uma equipe de } 5 \text { professores gastou } 12 \text { dias para corrigir as } \\
\text { provas de um vestibular. Considerando a mesma proporção, quantos dias } \\
\text { levariam } 30 \text { professores para corrigir essas provas? }\end{array}$ \\
\hline
\end{tabular}





Figura 4.9: Questões 1, 2 e 3

Percebe-se que, após a explanação do conteúdo, os alunos tiveram uma melhora no desenvolvimento das últimas questões, pois houve uma diminuição no índice dos alunos que não responderam as questões, principalmente na questão sobre regra de três inversamente proporcional.

\begin{tabular}{|l|l|}
\hline Questão 4 & $\begin{array}{l}\text { Em uma panificadora são produzidos } 90 \text { pães de } 15 \text { gramas cada um. } \\
\text { Caso queira produzir pães de } 10 \text { gramas, quantos pães iremos obter? }\end{array}$ \\
\hline Questão 5 & $\begin{array}{l}\text { Uma usina produz } 500 \text { litros de álcool com } 6000 \text { kg de cana de açúcar. } \\
\text { Determine quantos litros de álcool são produzidos com } 15000 \text { kg de cana. }\end{array}$ \\
\hline
\end{tabular}


Figura 4.10: Questões 4 e 5

\subsubsection{Atividade 6: Teorema de Pitágoras}

Essa atividade foi aplicada antes de o conteúdo ser ministrado (uma vez que o Teorema de Pitágoras faz parte do conteúdo do $9^{\circ}$ ano, mas somente será aplicado no $3^{\circ}$ bimestre). Dessa forma, a primeira questão teve o resultado esperado onde a maioria da turma não soube enunciar o Teorema de Pitágoras e nas duas questões seguidas, em especial a terceira questão, os alunos mal a responderam ou a erraram. 


\begin{tabular}{|l|l|}
\hline Questão 1 & $\begin{array}{l}\text { Você conhece o Teorema de Pitágoras? Se sim, enuncie esse famoso } \\
\text { teorema. }\end{array}$ \\
\hline Questão 2 & Quais são os nomes dos lados de um triângulo retângulo? \\
\hline Questão 3 & $\begin{array}{l}\text { Se um triângulo possui catetos medindo } 12 \mathrm{~cm} \text { e } 5 \mathrm{~cm} \text {, quanto mede } \\
\text { a hipotenusa? }\end{array}$ \\
\hline
\end{tabular}

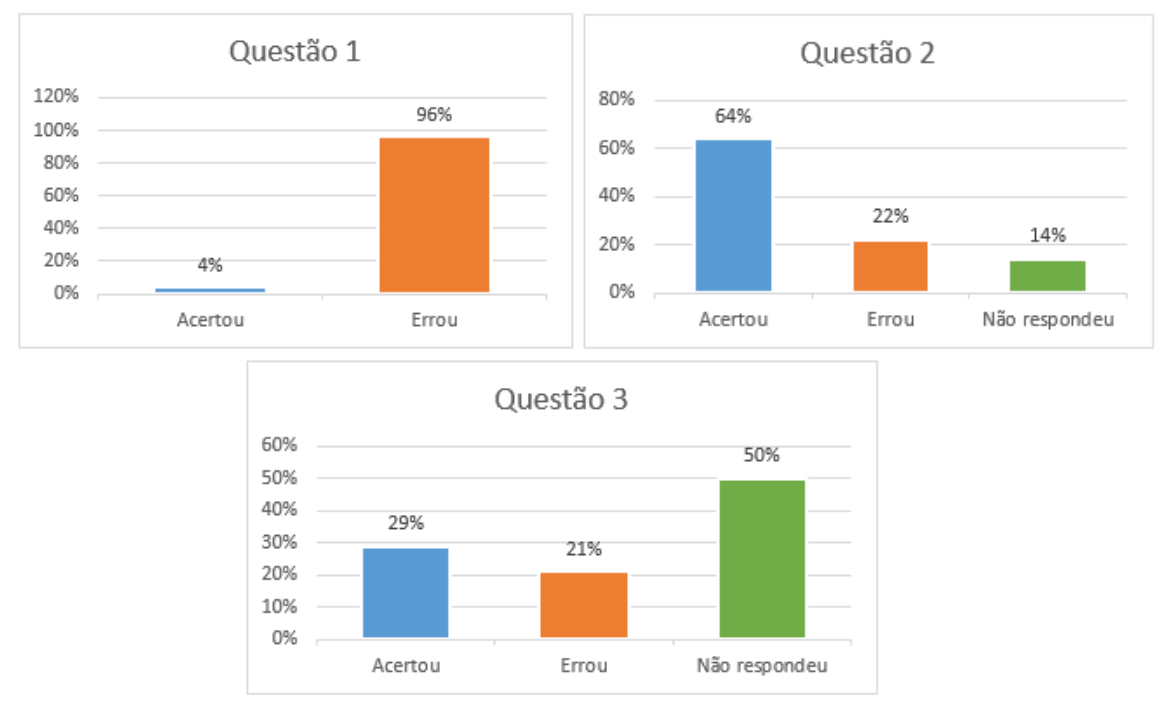

Figura 4.11: Questões 1, 2 e 3

Após a explanação do conteúdo, a Questão 4 foi bem respondida pelos alunos, mas a Questão 5 não teve o rendimento esperado. Mais uma vez, os alunos responderam a questão sem ter o devido cuidado, não sentindo a motivação necessária para a boa realização da mesma, uma vez que esse assunto ainda não havia sido abordado anteriormente em sala de aula.

\begin{tabular}{|l|l|}
\hline Questão 4 & $\begin{array}{l}\text { A Incógnita se enganou ao dizer quem era. Para atender ao } \\
\text { Teorema de Pitágoras, deveria dar a seguinte resposta: }\end{array}$ \\
\hline Questão 5 & A altura desse muro é: \\
\hline
\end{tabular}



Figura 4.12: Questões 4 e 5 


\subsubsection{Atividade sete: Ângulo e transferidor}

Os alunos haviam trabalhado com ângulos no ano anterior, porém não tinham utilizado o transferidor em nenhuma aula ainda, mas tinham um conhecimento prévio da utilização do mesmo. Dessa forma, as três primeiras questões tiveram um ótimo percentual de acerto por parte dos alunos.

\begin{tabular}{|l|l|}
\hline Questão 1 & Você sabe utilizar um transferidor? \\
\hline Questão 2 & Você sabe o que é um ângulo? \\
\hline Questão 3 & Quais são os tipos de ângulo que você conhece? \\
\hline Questão 4 & $\begin{array}{l}\text { Utilizando o transferidor, determine a medida e classifique os seguintes } \\
\text { ângulos: }\end{array}$ \\
\hline Questão 5 & Com o auxílio de um transferidor construa um ângulo de $70^{\circ}$. \\
\hline
\end{tabular}


Figura 4.13: Questões 1, 2, 3, 4 e 5

Após a explanação, permaneceu o bom rendimento na resolução das questões e os alunos gostaram muito de ter trabalhado com um instrumento matemático diferente dos usados no dia a dia. 


\begin{tabular}{|l|l|}
\hline Questão 6 & Com o auxílio de um transferidor construa um ângulo de $94^{\circ}$. \\
\hline Questão 7 & $\begin{array}{l}\text { Utilizando o transferidor, determine a medida e classifique os seguintes } \\
\text { ângulos: }\end{array}$ \\
\hline
\end{tabular}
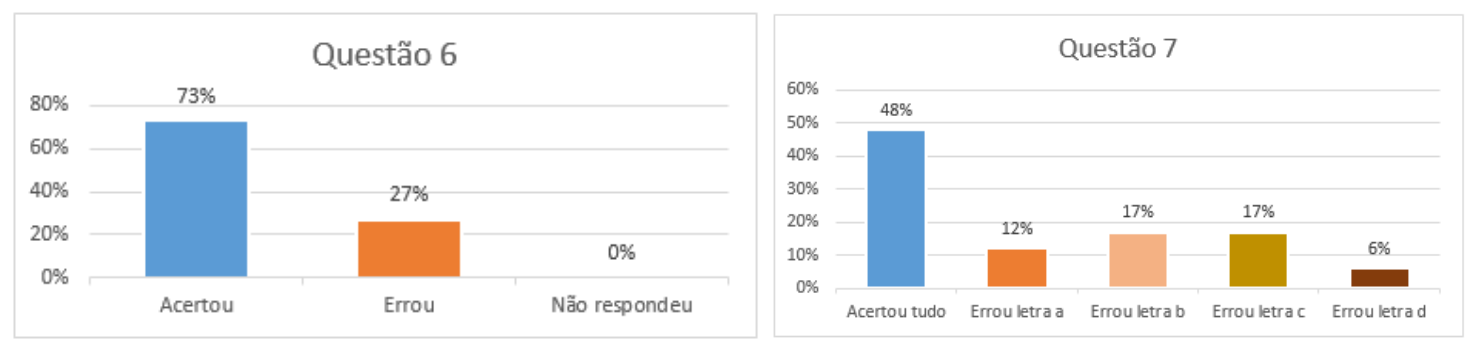

Figura 4.14: Questões 1 e 2

\subsubsection{Atividade 8: Compasso}

Assim como aconteceu na atividade anterior sobre o uso do transferidor, os alunos não haviam utilizado o compasso em nenhuma aula de Matemática, mas tinham conhecimento sobre os conceitos geométricos que foram aprendidos no ano anterior.

\begin{tabular}{|l|l|}
\hline Questão 1 & Você sabe utilizar um compasso? \\
\hline Questão 2 & Faça uma circunferência de raio $3 \mathrm{~cm}$. \\
\hline Questão 3 & Determine a reta mediatriz e o ponto médio do segmento AB. \\
\hline
\end{tabular}

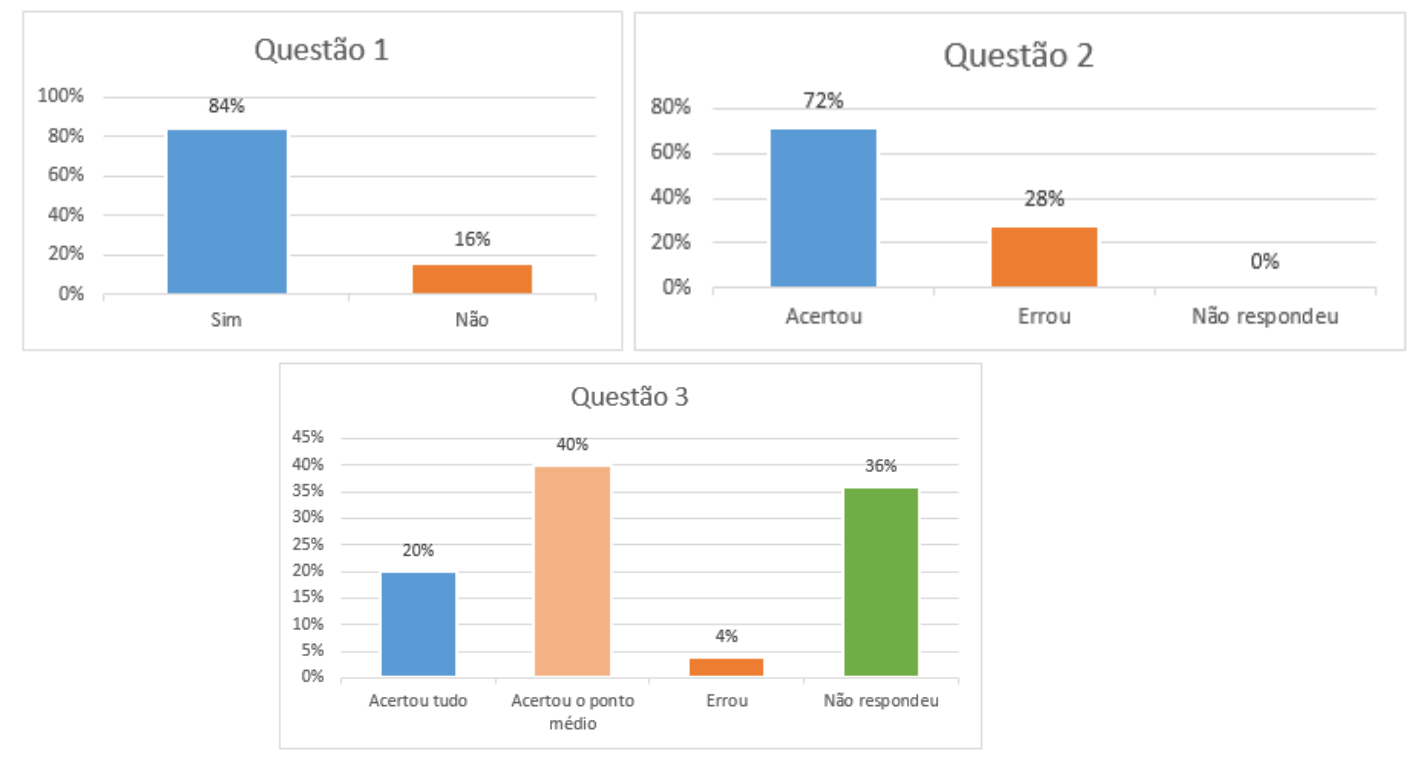

Figura 4.15: Questões 1, 2 e 3 
Após a explanação do conteúdo, do ensino de como usar o compasso e fazer algumas construções básicas, os alunos realizaram as demais atividades. Porém, como não tiveram aulas de desenho geométrico ou de construções geométricas, o rendimento na resolução das questões não foi tão bom quanto esperado, pois não sabiam realizar as atividades utilizando régua e compasso.

\begin{tabular}{|l|l|}
\hline Questão 4 & Determine o centro da circunferência dada a seguir. \\
\hline Questão 5 & $\begin{array}{l}\text { Com o auxílio de um compasso, transporte o ângulo AÔB para a } \\
\text { semirreta Or. }\end{array}$ \\
\hline Questão 6 & Efetue a operação graficamente, com o auxílio de um compasso. \\
\hline Questão 7 & Por um ponto P fora da reta, trace uma reta perpendicular à reta. \\
\hline
\end{tabular}

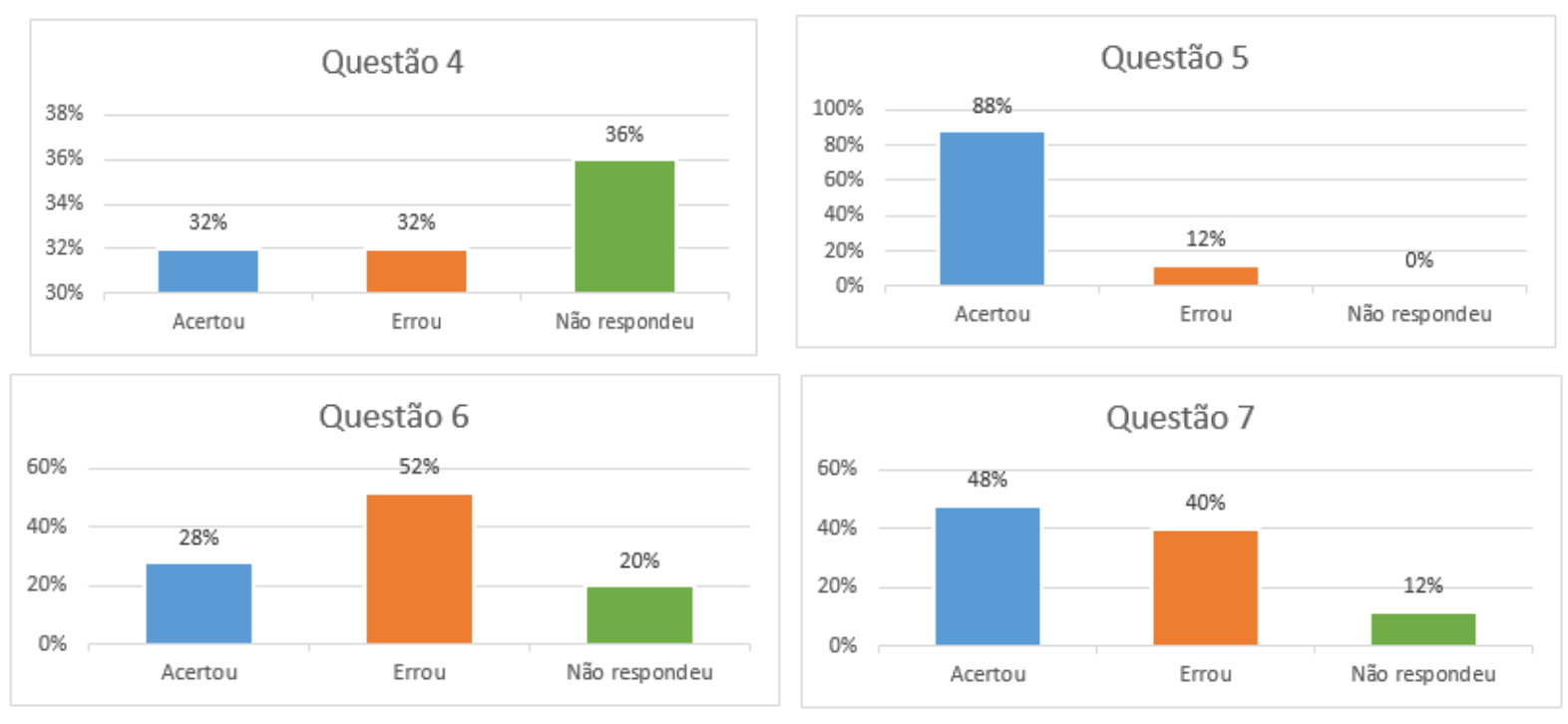

Figura 4.16: Questões 4, 5, 6 e 7

\subsubsection{Atividade 9: Trigonometria}

Mais uma atividade abordando um conteúdo em que os alunos não haviam estudado ainda no currículo regular. Diferentemente das demais atividades que eles não haviam estudado ainda, esse conteúdo, de fato, os alunos não conheciam, como se pode verificar nos gráficos a seguir.

\begin{tabular}{|l|l|}
\hline Questão 1 & Você sabe resolver questões utilizando as razões trigonométricas? \\
\hline Questão 2 & $\begin{array}{l}\text { Quais são os lados de um triângulo retângulo e quais são as razões } \\
\text { entre seus lados? }\end{array}$ \\
\hline
\end{tabular}



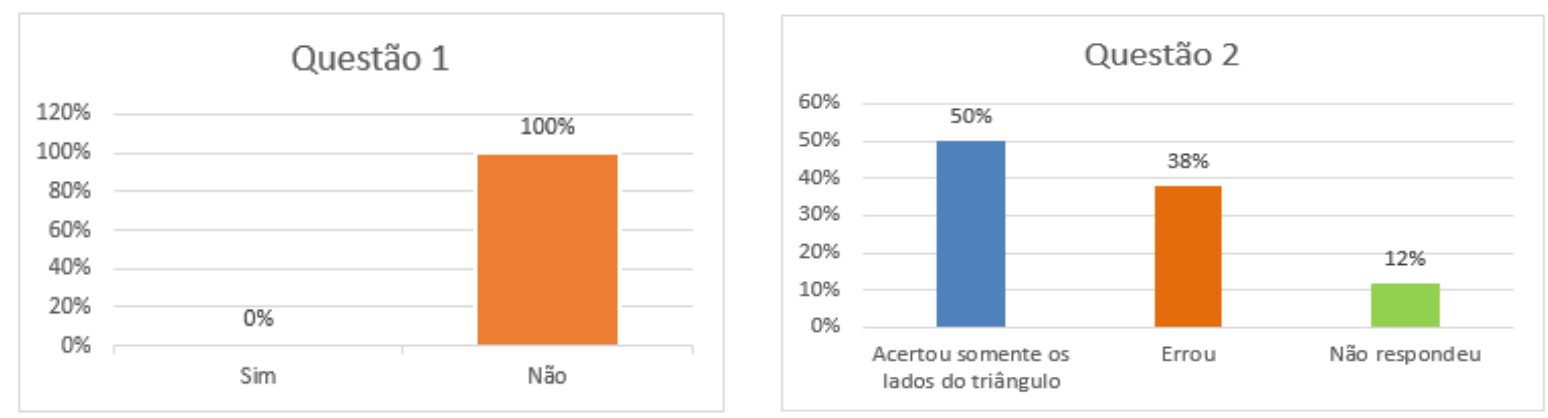

Figura 4.17: Questões 1 e 2

Em compensação, após a explanação do conteúdo e da abordagem histórica, os alunos responderam as questões conscientes do que estavam fazendo. Essa foi a atividade que eles ficaram mais empolgados para resolver, pois acharam muito interessante o conteúdo e, apesar de ser um conteúdo totalmente novo para os alunos, eles apresentaram um bom desempenho nessa atividade.

\begin{tabular}{|l|l|}
\hline Questão 3 & $\begin{array}{l}\text { Nos triângulos retângulo a seguir, determine as medidas de x e y } \\
\left.\text { indicadas (Use: sen }\left(65^{\circ}\right)=0,91 ; \cos \left(65^{\circ}\right)=0,42 ; \operatorname{tg}\left(65^{\circ}\right)=2,14\right) .\end{array}$ \\
\hline Questão 4 & $\begin{array}{l}\text { Considerando o triângulo retângulo } \mathrm{ABC} \text {, determine as medidas a e b } \\
\text { indicadas. }\end{array}$ \\
\hline
\end{tabular}
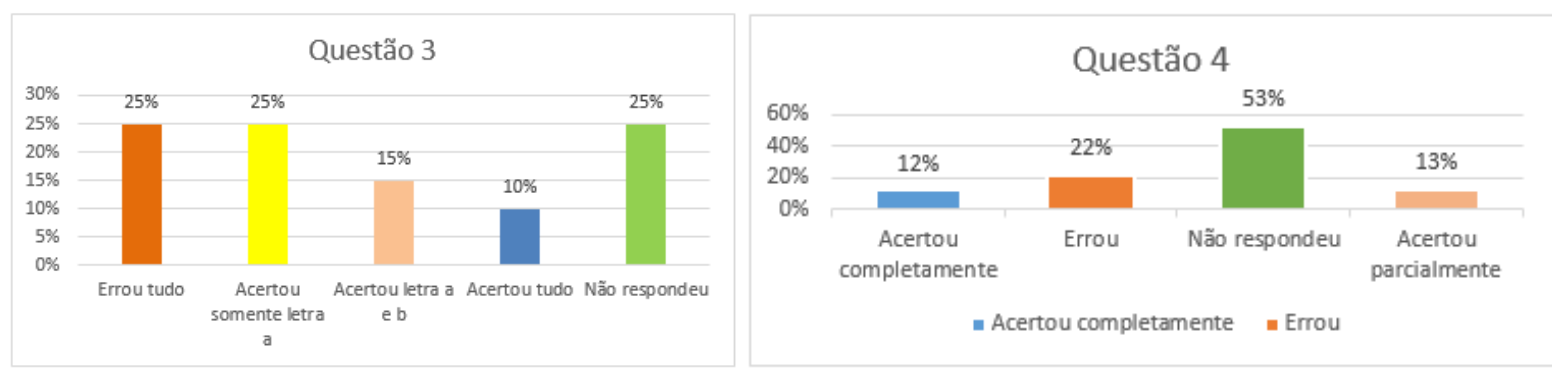

Figura 4.18: Questões 3 e 4

\subsubsection{Atividade 10: Construção do Teodolito e aplicação dos con- ceitos de Trigonometria}

Na concretização do projeto, com a construção do teodolito, a empolgação dos alunos refletiu no desempenho que obtiveram na atividade que foi além do esperado. Todos se ajudaram na construção e na realização da atividade proposta fora da sala de aula, onde 
os alunos determinariam a altura de três prédios. Percebe-se, pela análise dos gráficos, que a maioria da turma alcançou o objetivo e conseguiu determinar a altura dos prédios em questão com o auxílio do teodolito fabricado por eles mesmos.

\begin{tabular}{|l|l|}
\hline Questão 1 & Utilizando o teodolito determine a altura do prédio A. \\
\hline Questão 2 & Utilizando o teodolito, qual a altura do prédio B? \\
\hline Questão 3 & Utilizando o teodolito, qual a altura do prédio C? \\
\hline
\end{tabular}

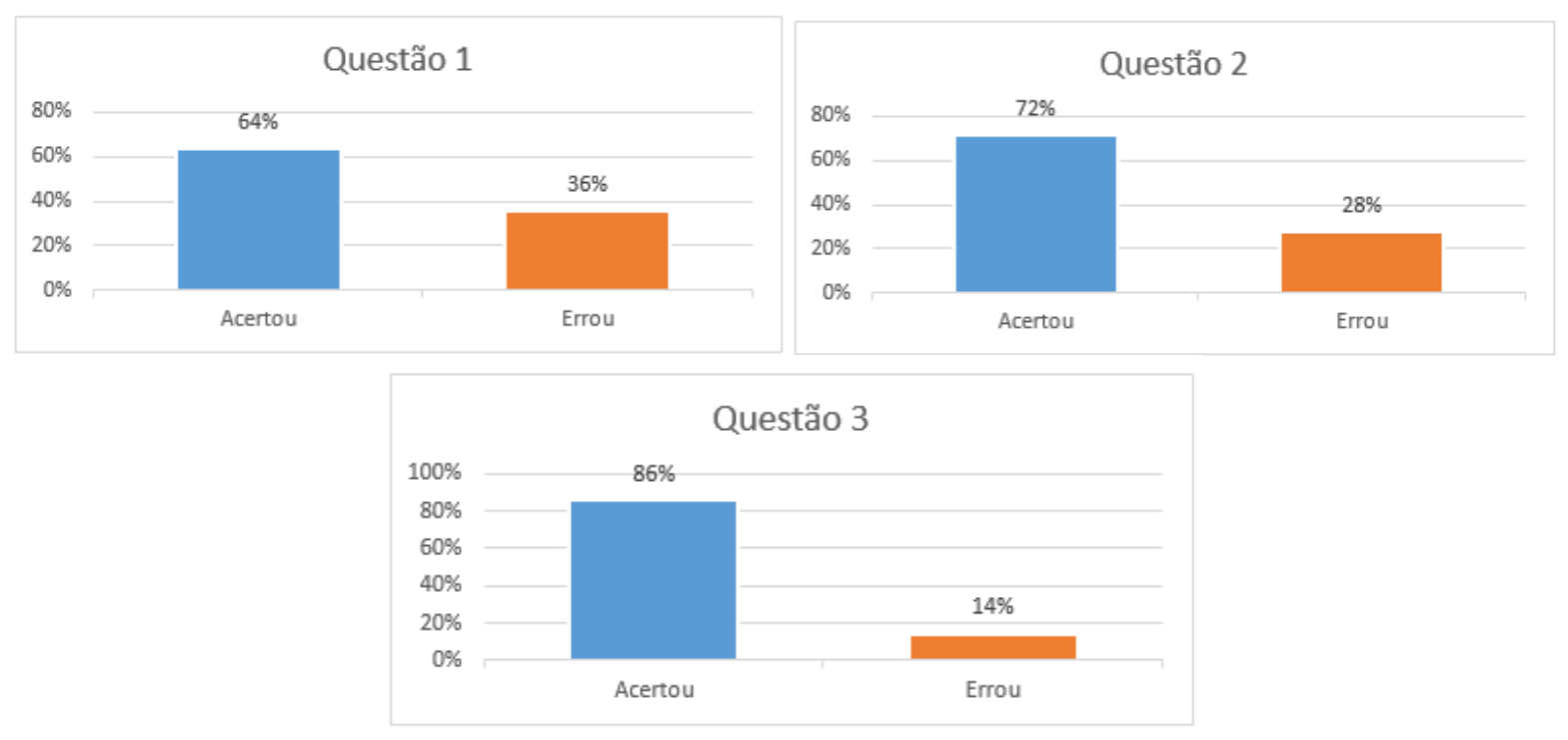

Figura 4.19: Questões 1, 2 e 3

\subsection{Breve Análise Qualitativa}

Fazendo uma breve análise qualitativa sobre o aprendizado dos alunos com as 10 atividades aplicadas verificamos que:

*Houve uma melhora de concentração, interesse e participação nas aulas de Matemática.

*Os alunos sentiram-se mais motivados e interessados em pesquisar a história dos conteúdos que seriam estudados ou que já haviam estudado.

* Mesmo com os erros obtidos nas atividades, percebe-se que os alunos adquiriram co- nhecimento sobre os conteúdos trabalhados, aumentando suas notas em provas e realizando mais as tarefas de casa.

*Os alunos continuaram utilizando o teodolito no dia a dia, medindo a altura de uma cesta de basquete na aula de educação física ou medindo a altura do prédio ou casa em que moravam. 


\subsection{Análise da Pesquisa de Opinião}

Esta seção tem por objetivo analisar a aceitação do projeto por parte dos alunos e observar as suas opiniões. Ressalta-se, novamente, que essa pesquisa foi aplicada após o término das atividades e num momento anterior a explanação do conteúdo trigonometria, que seria visto somente no terceiro bimestre do presente ano.

As duas primeiras questões visavam verificar o conhecimento dos alunos acerca do Teodolito.
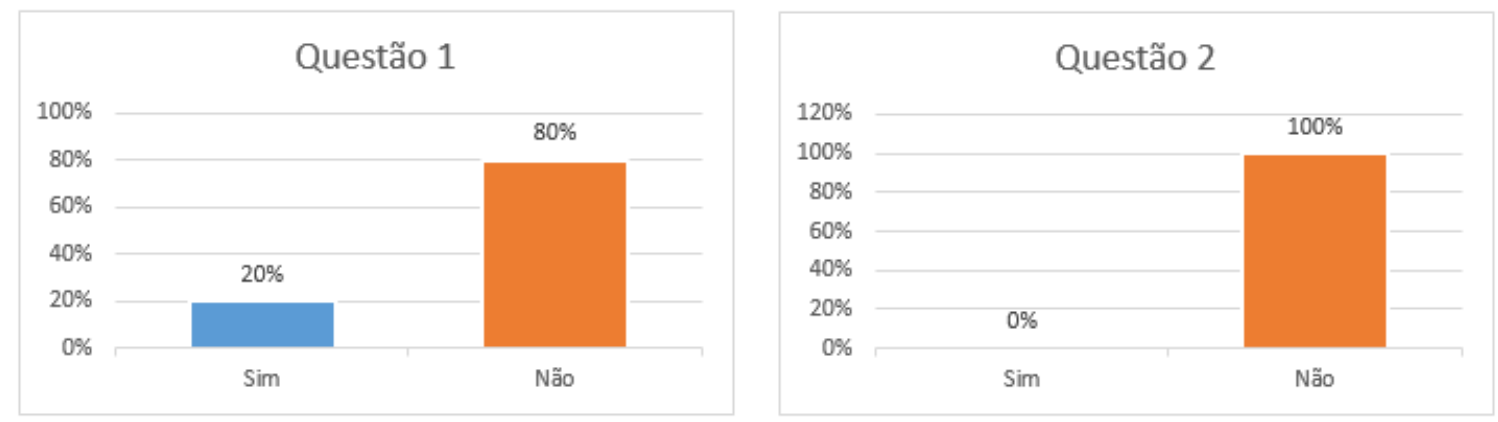

Figura 4.20: Questões 1 e 2

Pela análise dos gráficos percebe-se que mais da metade da turma não conhecia o teodolito e que a totalidade da turma nunca o tinha utilizado antes.

As questões que vieram em seguida visavam aferir se os alunos julgavam que o projeto auxiliou na aprendizagem dos conteúdos, bem como se foi interessante e motivador.

\begin{tabular}{|l|l|}
\hline Questão 3 & $\begin{array}{l}\text { Você julgou interessante trabalhar com a Matemática em um } \\
\text { ambiente fora de sala de aula, com atividades práticas? }\end{array}$ \\
\hline Questão 4 & $\begin{array}{l}\text { Você acredita que o projeto auxiliou na aprendizagem do } \\
\text { conteúdo de Matemática que foi ministrado em sala de aula? }\end{array}$ \\
\hline Questão 5 & \begin{tabular}{l} 
Você se sentiu motivado para participar das atividades do projeto? \\
\hline Questão 6
\end{tabular} \\
$\begin{array}{l}\text { O seu interesse em aprender a matéria aumentou pelo fato de estar } \\
\text { utilizando - a no projeto? }\end{array}$ \\
\hline
\end{tabular}



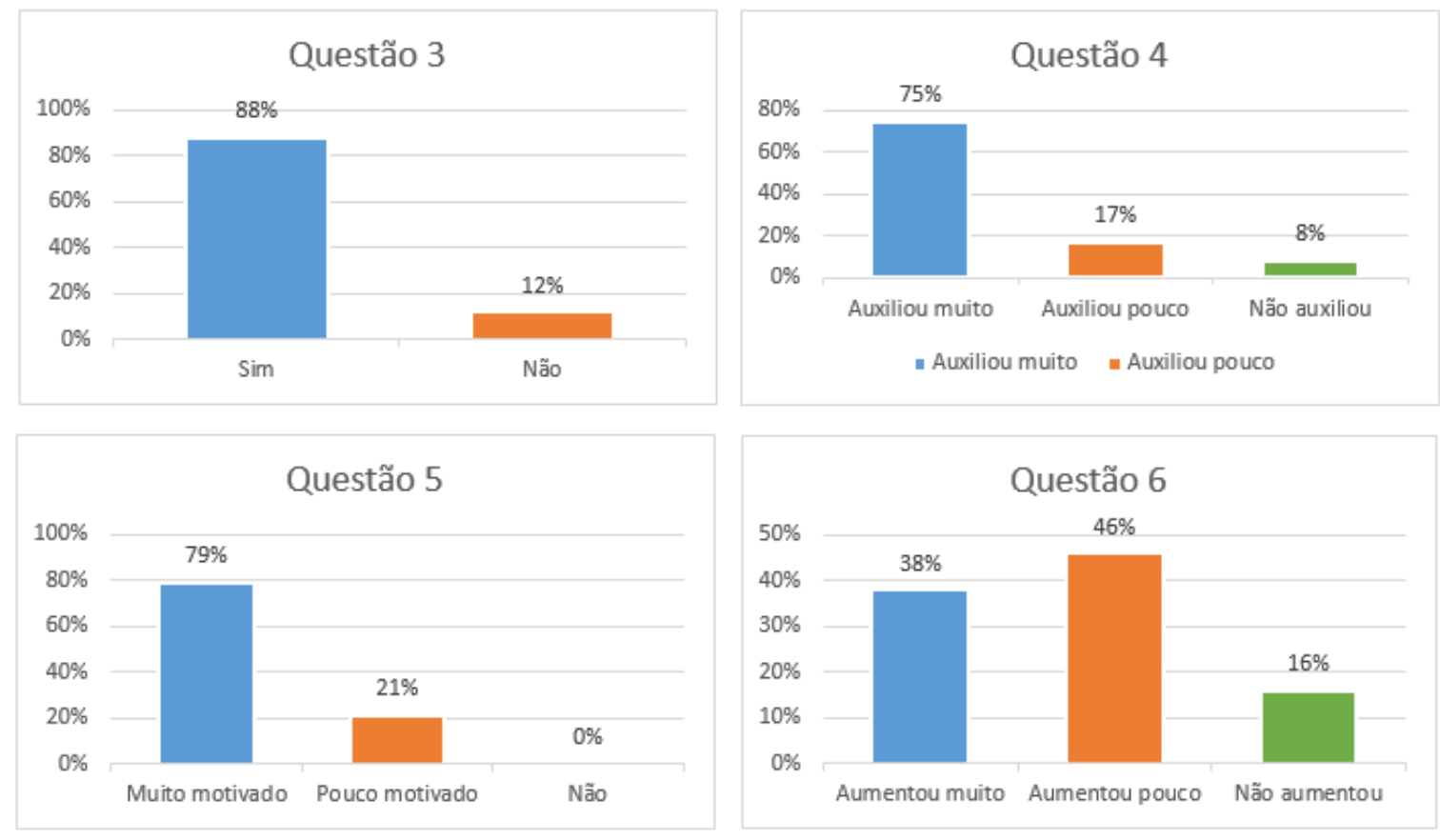

Figura 4.21: Questões 3, 4, 5 e 6

Verifica-se, com a análise da Questão 3, que a maioria dos alunos julga interessante trabalhar com a Matemática fora do ambiente de sala de aula. Isso demonstra a nova tendência nas salas de aula em que os alunos preferem aulas mais criativas, diferenciadas, que fujam do tradicional, onde somente o professor fala e o aluno é apenas um espectador que assiste e copia o quadro.

O aluno quer aprender, construir o conhecimento juntamente com o professor, participando do processo de ensino aprendizagem ativamente.

Já na Questão 4, verifica-se que a maioria da turma acredita que o projeto auxiliou bastante na aprendizagem em sala de aula. Apenas uma pequena porcentagem da sala achou que o projeto auxiliou pouco, enquanto uma parcela menor ainda achou que não auxiliou em nada. Vale ressaltar que, por diversas vezes, foi necessário intervir com conversas motivadoras para que os alunos entendessem a importância do projeto, todavia, o fato de não "valer ponto" fez com que alguns alunos não participassem da melhor maneira possível do projeto.

Analisando a Questão 5, percebe-se que a maioria da sala se sentiu motivada para participar do projeto, enquanto a parcela da turma que não se sentiu motivada foi exatamente aqueles que não acharam que o projeto não os auxiliou na aprendizagem em sala, conforme citado no parágrafo anterior.

Na Questão 6, verifica-se que praticamente metade da turma achou que o projeto 
aumentou pouco o interesse pelas aulas de Matemática, enquanto 38\% achou que esse interesse aumentou bastante. Vale ressaltar que essa turma era uma turma bastante desinteressada e ter esse percentual já foi uma grande vitória.

$\mathrm{Na}$ sequência das perguntas, temos aquelas que tinham por objetivo verificar quais conteúdos os alunos aprenderam com maior facilidade ou dificuldade e se houve algum conteúdo que eles não aprenderam. O resultado obtido foi o seguinte:

\begin{tabular}{|l|l|}
\hline Questão 7 & Qual dos conteúdos você sentiu maior facilidade ? \\
\hline Questão 8 & Qual dos conteúdos você sentiu maior dificuldade? \\
\hline Questão 9 & Você deixou de aprender algum conteúdo ? \\
\hline
\end{tabular}

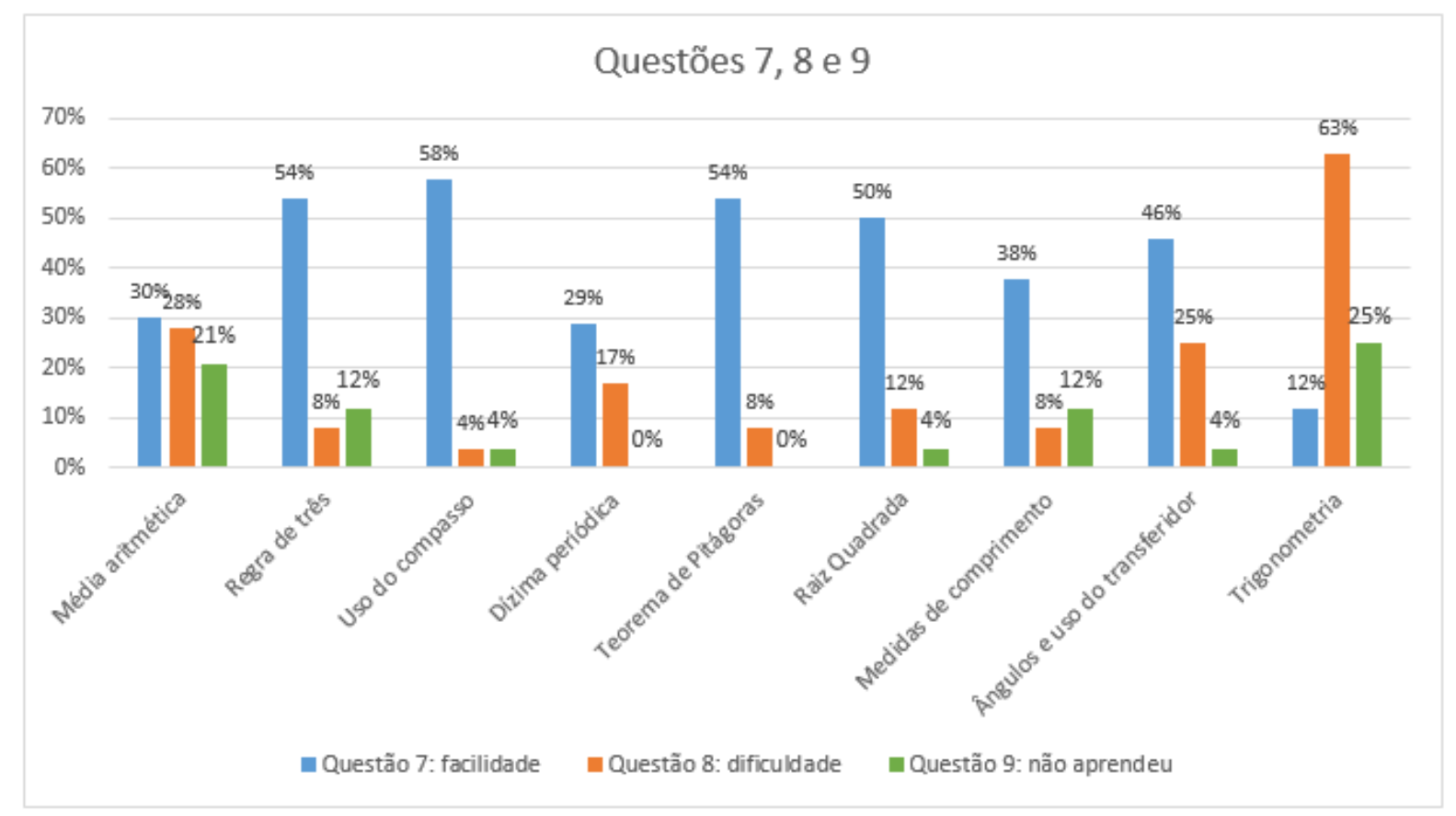

Figura 4.22: Questões 7, 8 e 9

Pela análise gráfica das Questões 7, 8 e 9, percebe-se que a atividade que os alunos apresentaram maior facilidade foi o uso do compasso e a que eles apresentaram maior dificuldade foi trigonometria, sendo esta também aquela em que os alunos disseram que não aprenderam, ressaltando, novamente, que esse conteúdo ainda não foi oficialmente ensinado na escola, pois será ensinado somente no terceiro bimestre.

Na sequência da pesquisa de opinião, as Questões 10 e 11 tinham como objetivo verificar se os alunos continuariam utilizando o teodolito e se indicariam o projeto para outros colegas. 


\begin{tabular}{|l|l|}
\hline Questão 10 & Você pretende continuar utilizando o seu teodolito? \\
\hline Questão 11 & Você indicaria o projeto para outros colegas? \\
\hline
\end{tabular}
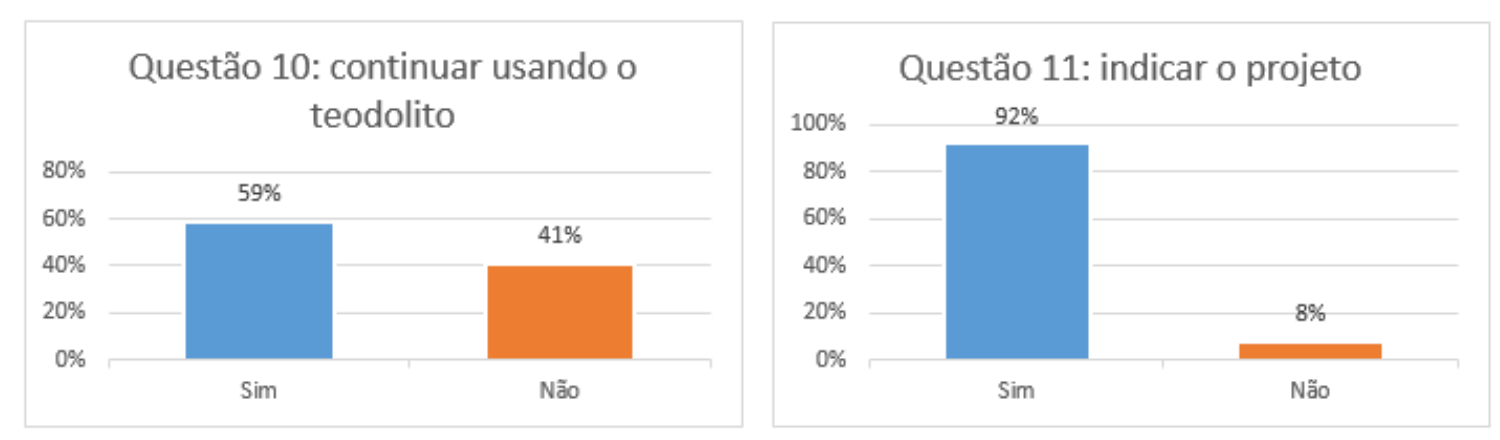

Figura 4.23: Questões 10 e 11

Pode-se perceber, pela análise dos gráficos, que a maioria pretende continuar utilizando o teodolito, ou seja, o projeto contribuiu não só para o desenvolvimento dos conteúdos matemáticos, como também para o conhecimento de um instrumento que utiliza conceitos matemáticos aprendidos durante o ano, o que contextualiza o ensino da Matemática para os alunos. Mais de $90 \%$ dos alunos disseram que indicariam o projeto para outros colegas, mesmo não utilizando mais o teodolito.

Para reafirmar a opinião dos discentes sobre as atividades, a última questão pedia para que avaliassem com uma nota, de 0 a 10, do projeto. O resultados segue a seguir:

\section{Questão 12 Dê uma nota de 0 a 10 para o projeto:}



Figura 4.24: Questão 12 
Portanto, pela avaliação dos alunos, a nota do projeto é 8,97. Para finalizar a participação dos alunos, foi disponibilizado um espaço para que pudessem expressar o que o projeto representou para eles. Seguem algumas colocações:

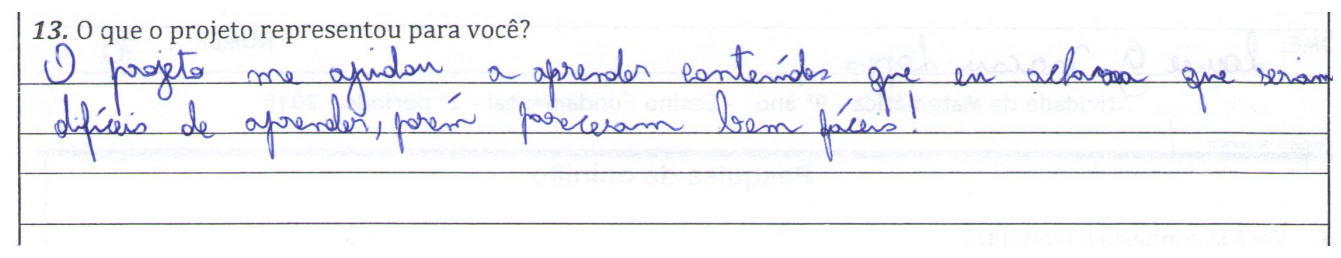

Figura 4.25: Opinião 1

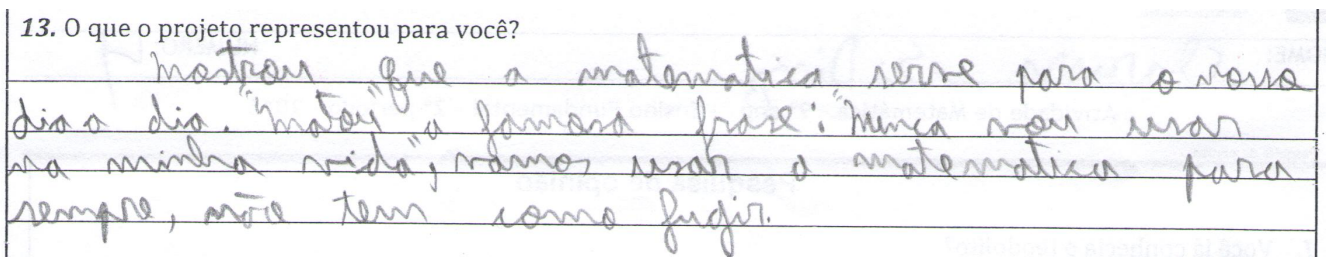

Figura 4.26: Opinião 2

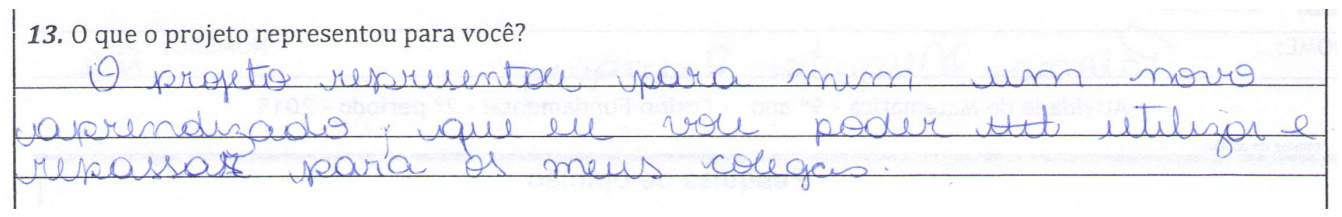

Figura 4.27: Opinião 3 


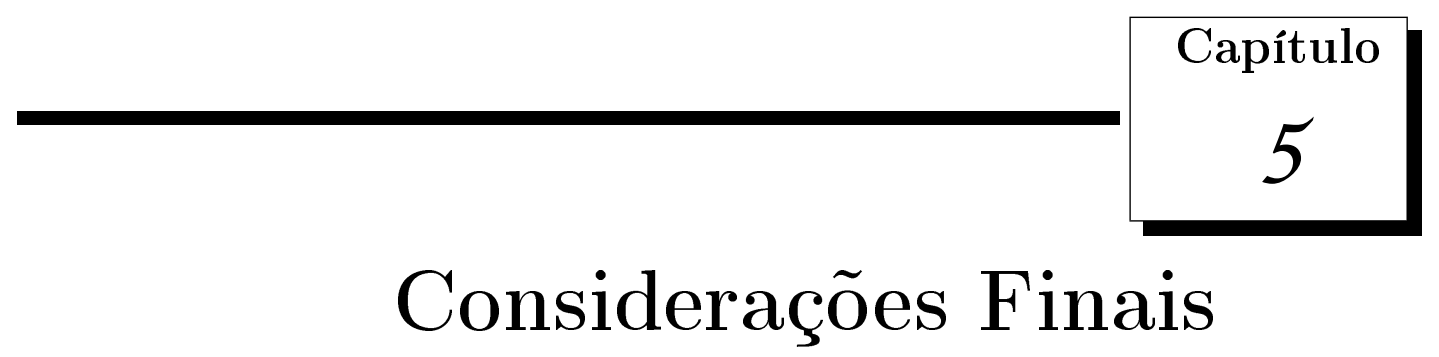

O ensino da Matemática não é nada fácil, pois existem diversos mitos e paradigmas que dificultam tal ação, tais como: "a matéria é difícil", "não serve para nada", "aonde irei utilizar isso na minha vida?". Isto torna o trabalho do professor um verdadeiro desafio, pois ele deve se desdobrar para tentar motivar seus alunos a gostarem e aprenderem a tal temida disciplina por boa parte dos discentes. Segundo Carraher, Carraher e Schilieman (em [16]):

O Ensino da Matemática se faz, tradicionalmente, sem referência ao que os alunos já sabem. Apesar de todos reconhecerem que os alunos podem aprender sem que o façam na sala de aula, tratamos nossos alunos como se nada soubessem sobre tópicos ainda não ensinados (p.21).

Dessa forma, o desafio do professor torna-se mais complicado ainda, pois precisa considerar os conhecimentos e experiências de cada indivíduo de sua sala de aula e se desdobrar com todas as adversidades que existem no dia a dia de uma escola. Ainda segundo Carraher, Carraher e Schilieman (em [16]): "A aprendizagem de matemática na sala de aula é um momento de interação entre a matemática organizada pela comunidade científica, ou seja, a matemática formal, e a matemática como atividade humana" (p.21).

A partir disso, a proposta deste trabalho foi tentar motivar e inspirar alunos a visualizarem e aprenderem a Matemática a partir de seus conhecimentos e de uma forma diferenciada da qual estavam habituados. De acordo com Toledo e Toledo:

(...) resolução de problemas. Essa proposta, mais atual, visa à construção de conceitos matemáticos pelo aluno através de situações que estimulam a sua curiosidade Matemática. Através de suas experiências com problemas de naturezas diferentes o aluno interpreta o fenômeno matemático e procura explicá-lo dentro de sua concepção de Matemática envolvida (...) (p. 14/15). 
O fato de cada atividade conter a contextualização histórica sobre cada conteúdo motivou os alunos a realizarem cada uma delas de uma forma diferente da usual, pois despertou a curiosidade deles quanto à história da Matemática em cada conteúdo estudado.

Além do contexto histórico, a construção e utilização do Teodolito foi o que mais agradou aos discentes, pois puderam sair do ambiente da sala de aula e aplicar os conhecimentos adquiridos em uma atividade diferenciada que aplicava a Trigonometria de forma contextualizada.

Através da realização desse projeto com os alunos do $9^{\circ}$ ano, houve uma melhora na autoestima da turma nas aulas de Matemática, fazendo com que os alunos tivessem uma maior satisfação e aceitação em participar das aulas, trazendo dúvidas e curiosidades, além de uma melhora significativa nas notas das provas, o que comprova o grande ganho de conhecimento e aprendizado por boa parte dos discentes.

Esses fatos foram comprovados com a análise dos resultados das atividades, com a pesquisa de opinião realizada pelos alunos e pela análise/comparação feita, posteriormente, das notas dos discentes após a aplicação do projeto, salientando que o projeto foi aplicado no primeiro semestre de 2015 e essa comparação das notas pôde ser feita no segundo semestre.

Por fim, apesar de ser uma experiência desafiadora, foi extremamente gratificante visualizar a mudança do olhar dos alunos quanto ao ensino e à aprendizagem da Matemática e, principalmente, da empolgação em sair de sala de aula e construir um aparelho totalmente novo para utilizarem um conteúdo que haviam acabado de aprender. 


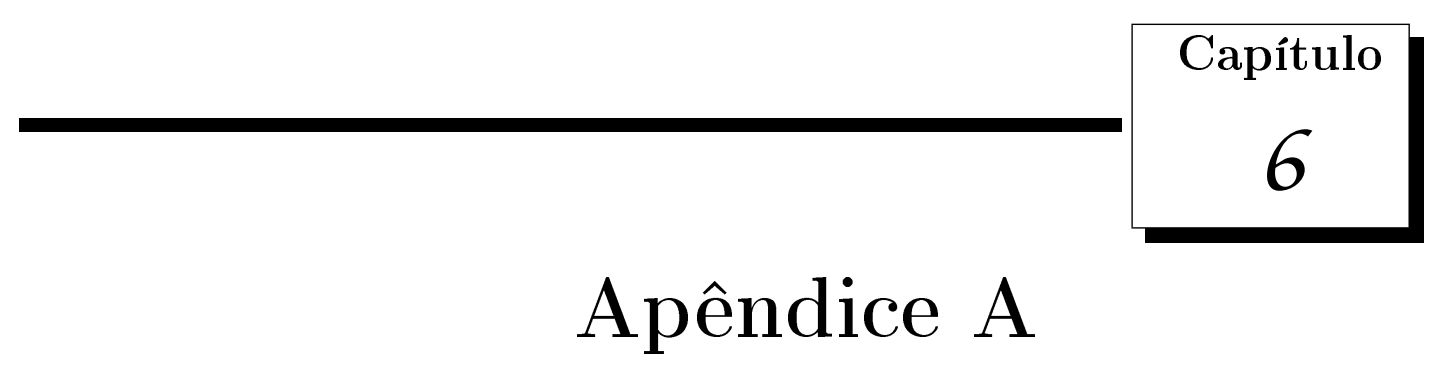

Destacam-se nesse apêndice as atividades utilizadas para o desenvolvimento do projeto em sala de aula, no formato em que foi entregue aos alunos. É importante ressaltar que as atividades estão apresentadas na sequência em que foram desenvolvidas.

Foram aplicadas 10 atividades como forma de construir o conhecimento necessário para se chegar a Trigonometria (Atividade 10) e mais uma pesquisa de opinião (Atividade 11) na qual os alunos avaliaram toda a realização do projeto destacando as atividades que tiveram facilidade ou dificuldade.

Cada uma destas atividades foi realizada no período de uma aula no período matutino, sendo que na construção do Teodolito, essa foi desenvolvida no período vespertino, na área externa da escola, com uma duração de 3 aulas, pois os alunos precisavam construir o seu próprio Teodolito, fazer as medições necessárias e os cálculos pertinentes para a conclusão dessa.

Além disso, cada atividade foi composta por questões de sondagem (para verificar o que os alunos lembravam ou tinham de conhecimento sobre o assunto que seria trabalhado na atividade), questões para serem realizadas após a explanação do conteúdo e um breve histórico sobre cada assunto trabalhado, para que os discentes tivessem um olhar diferenciado em relação ao ensino e aprendizagem da Matemática e pudessem conhecer um pouco da História da Matemática. 


\section{Universidade de Brasília \\ Departamento de Matemática}

\section{Atividade 1}

\section{Raiz quadrada}

Nome: Data:

Nessa atividade, responda somente as questões 1 e 2 utilizando caneta azul ou preta.

Em seguida, faça a correção das questões juntamente com a professora. Após a explicação responda as questões 3, 4, 5 e 6.

1) Você sabe calcular a raiz quadrada de um número real?

2) Qual é o valor de $\sqrt{4}$ ?

3) Por que não tem sentido calcular $\sqrt{-4}$ no conjunto dos números reais?

4) Qual a raiz quadrada de 0,09? E de 1,44?

5) Qual a raiz quadrada de 32 ? E de 512 ?

6) Qual é o valor de $\sqrt{\frac{8}{36}}$ ?

\section{Breve histórico}

Tem-se notícia que, por volta do século XVI, foi utilizado o símbolo da raiz quadrada pela primeira vez. Porém, em 1202, no livro Líber Abaci (traduzido como livro do ábaco ou livro de cálculo) de Leonardo de Pisa (o famoso Fibonacci, nascido por volta de 1170), traz o seguinte trecho escrito em suas páginas: "radix quadratum 16 aequalis 4", escrito em latim, que traduzindo para o português, é: "O lado do Quadrada de 16 é igual a 4". Apesar da semelhança das palavras, a palavra Radix não tem nada a ver com Raiz. A tradução correta de Radix é Lado.

A origem do símbolo da raiz quadrada $\sqrt{ }$ está associado a um abreviamento da palavra radix, pois, com o passar do tempo e das cópias em cima de cópias, resultou no símbolo que usamos hoje em dia, um alongamento ou variância da letra $r$." [1] 


\section{Universidade de Brasília} Departamento de Matemática

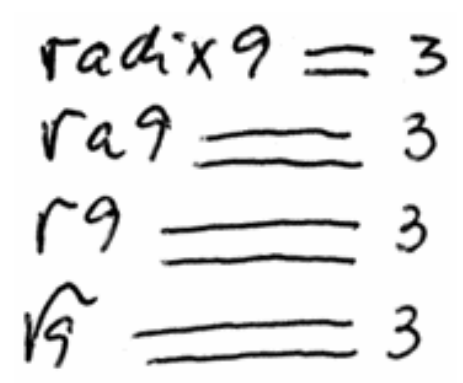

$\mathrm{Na}$ Grécia Antiga, os matemáticos conheciam apenas os números inteiros e as frações. Surgiu o Teorema de Pitágoras (a soma dos quadrados dos catetos é igual ao quadrado da hipotenusa) e, logo em seguida, os pitagóricos (pensadores matemáticos que faziam parte da Escola Pitagórica e que se interessavam pelo estudo das propriedades dos números por volta do século IV a.C.) tentaram calcular a diagonal de um quadrado de lado 1. Porém, não encontravam um valor inteiro nem que pudesse ser representado por meio de uma fração (racional). Para os matemáticos da época, isso era inquietante pois contrariava tudo que acreditavam e ensinavam, uma vez que tinha um certo receio do novo. Assim, esconderam essa informação, até que Hipaso de Metaponto a divulgou, custando-Ihe a própria vida, como conta a lenda. [2]

Assim que surgiu os números irracionais, da impossibilidade de se escrever números racionais, que foi um marco muito importante para o pensamento humano $\mathrm{e}$ para a história da matemática. A diagonal do quadrado de lado 1 é conhecida hoje por $\sqrt{2}$ e pode ser calculada pelo Teorema de Pitágoras: $d^{2}=1^{2}+1^{2}=2 \Rightarrow$ portanto $d=$ $\sqrt{2}$.

\section{Referências bibliográficas}

[1] (http://matematicaenigmatica.blogspot.com.br/2009/11/origem-do-simbolo-daraiz-quadrada.html acessado em 13/01/2015)

[2] (https://sites.google.com/site/numerosnemtodossaoracionais/introducao/raizde-2 acessado em 13/01/2015) 


\section{Atividade 2}

\section{Média aritmética}

Nome:

Data:

Nessa atividade, responda somente as questões 1, 2, 3 e 4 utilizando caneta azul ou preta. Em seguida, faça a correção das questões juntamente com a professora. Após a explicação responda as questões 5 e 6.

1) Você sabe calcular a média aritmética entre dois ou mais números?

2) Um grupo de pessoas apresenta as idades de 10, 13, 15 e 17 anos. Se uma pessoa de 12 anos se juntar ao grupo, o que acontecerá com a média de idade do grupo?

3) Um aluno tirou as notas 5, 7, 9 e 10 em quatro provas. Qual será a sua média no final do bimestre, sabendo que a média utilizada será a aritmética?

4) (VUNE1001/03 - Op. Telemarketing Recepcionista - 2010) - Ao pesquisar o preço de um determinado produto em 20 postos de vendas, encontraram-se 3 preços diferentes, sendo a distribuição representada em um gráfico.

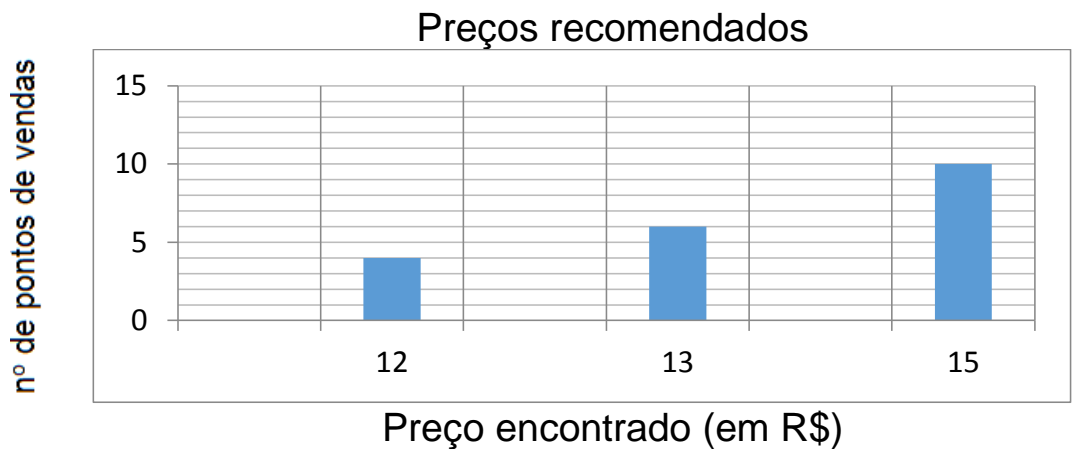

Considerando esses 20 postos de vendas, o preço médio do produto é igual a
(A) $\mathrm{R} \$ 12,80$.
(B) $R \$ 13,20$.
(C) $\mathrm{R} \$ 13,80$.
(D) $\mathrm{R} \$ 14,20$.
(E) $R \$$ 14,80 .

5) O dólar é considerado uma moeda de troca internacional, por isso o seu valor diário possui variações. Acompanhando a variação de 
preços do dólar em reais durante uma semana verificou-se as variações de acordo com a tabela informativa:

\begin{tabular}{|l|l|l|l|l|}
\hline Segunda & Terça & Quarta & Quinta & Sexta \\
\hline$R \$ 3,23$ & $R \$ 3,22$ & $R \$ 3,27$ & $R \$ 3,25$ & $R \$ 3,26$ \\
\hline
\end{tabular}

Determine o valor médio do preço do dólar nesta semana.

6) (PMES0802/01 - Soldado PM - 2ª Classe - Militar Estadual (Masc) - 2008) Uma pessoa comprou 5 garrafas de suco de frutas, uma de cada tipo. A tabela mostra o preço de cada garrafa de suco.

\begin{tabular}{|c|c|c|c|c|c|}
\hline Sucos & Maracujá & Laranja & Caju & Abacaxi & Uva \\
\hline $\begin{array}{c}\text { Preço por } \\
\text { garrafa }\end{array}$ & 5,70 & 3,50 & 2,30 & 3,20 & $?$ \\
\hline
\end{tabular}

Sabendo que nessa compra o preço médio de uma garrafa foi $R \$ 3,80$, pode-se concluir que o preço da garrafa de suco de uva é
(A) $R \$ 3,80$.
(B) $R \$ 4,20$.
(C) $R \$ 4,30$.
(D) $R \$ 4,70$.
(E) $R \$ 4,90$.

\section{Breve histórico}

Um dos matemáticos pitagóricos, conhecido por Arquitas de Tarento definiu, por volta de 400 a.C., que existiam três tipos de média (a aritmética, geométrica e a harmônica). Onde um número é a média aritmética de dois outros quando o excesso do primeiro para o segundo é igual ao excesso do segundo para o terceiro $(x-m=m-y)$ e após as devidas manipulações chegou-se ao

que se conhece hoje $\left(m=\frac{x+y}{2}\right)$. Generalizando, temos que a média aritmética (A) da lista de $n$ números $x_{1}, x_{2}, \ldots, x_{n}$ é definida por:

$$
A=\frac{x_{1}+x_{2}+\ldots+x_{n}}{n} \text {. }
$$

A média geométrica tem várias aplicações e é muito utilizada na área de finanças e de engenharia e vários problemas de desigualdades na geometria são resolvidos através dessa média. A média geométrica $(G)$ dos $n$ números positivos $\mathrm{x}_{1}, \mathrm{x}_{2}, \ldots, \mathrm{x}_{\mathrm{n}}$ é definida por: 


$$
G=\sqrt[n]{x_{1} x_{2} \ldots x_{n}}
$$

A média harmônica é utilizada quando se trata de grandezas inversamente proporcionais. A média harmônica $(H)$ dos $n$ números positivos $x_{1}$, $\mathrm{X}_{2}, \ldots, \mathrm{X}_{\mathrm{n}}$ é definida por: $\boldsymbol{H}=\frac{n}{\frac{1}{x_{1}}+\frac{1}{x_{2}}+\cdots+\frac{1}{x_{n}}}$.

Existe uma relação que envolve as três médias, chamada de Desigualdade das médias onde a média aritmética é maior ou igual que a média geométrica que, por sua vez, é maior ou igual que a média harmônica:

$$
\boldsymbol{A} \geq \boldsymbol{G} \geq \boldsymbol{H}
$$

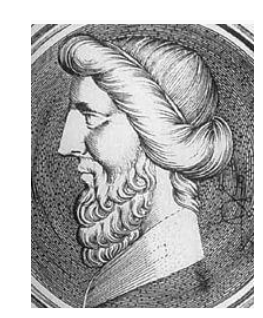

Arquitas

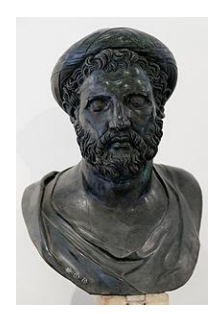

Busto de Arquitas da Vila dos Papiros, em Herculano

Um exemplo de como a média aritmética foi utilizada na antiguidade é retratada na história a seguir: os anglo-saxônicos utilizavam como unidade de medida de comprimento o pé equivalente a 30,48 centímetros. Conta-se que um rei da Inglaterra ordenou que seus oficiais fossem a uma igreja e, após o culto, enfileirassem os dezesseis primeiros homens que de lá saíssem. Cada um dos homens a partir do segundo deveria encostar o dedo grande do seu pé no calcanhar do homem a sua frente. Este comprimento, que foi facilmente medido com uma corda, foi dividido em dezesseis partes iguais e tornou-se o "pé" oficial na Inglaterra, naquela época. Em certos países eram utilizados alguns padrões tais como: o pé romano $(29,6 \mathrm{~cm})$, o pé comum $(31,7 \mathrm{~cm})$ e o pé do Norte $(33,6$ $\mathrm{cm})$.

\section{Referências bibliográficas}

[1] http://www.diaadiaeducacao.pr.gov.br/portals/pde/arquivos/2170-8.pdf em $13 / 01 / 2015$

[2] MORGado, Augusto César. CARVALHO, Paulo Cezar Pinto. Matemática discreta. Coleção PROFMAT. SBM, 2014, Rio de Janeiro, 1ㄹ Edição. 


\section{Atividade 3}

Dízima Periódica

Nome: Data:

Nessa atividade, responda somente as questões 1, 2, 3 e 4 utilizando caneta azul ou preta. Em seguida, faça a correção das questões juntamente com a professora. Após a explicação responda as questões 5 e 6.

1) Você sabe o que é a geratriz de uma dízima periódica?

2) Você sabe transformar uma dízima periódica em fração?

3) Transforme a dízima periódica 0,555... em uma fração irredutível.

4) Transforme a dízima periódica $2,1333 \ldots$ em uma fração irredutível.

5) Transforme a dízima periódica $0,1212 \ldots$ em uma fração irredutível.

6) Transforme a dízima periódica 0,0222... em uma fração irredutível.

\section{Breve Histórico}

Dízima periódica é um número racional que se origina de uma fração geratriz. Por volta de 3000 a.C., o número fracionário surgiu quando um antigo faraó chamado Sesostris repartiu o solo do Egito as margens do rio Nilo entre seus habitantes, usando cordas como unidade de medida, de modo que usavam essas cordas para fazer a medição e, por mais adequada que fosse a unidade de medida, dificilmente cabia um número inteiro de vezes nos lados do terreno.

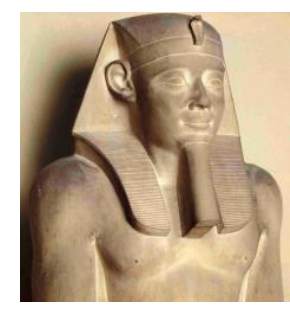

Estátua do faraó Sesostris 
Foi por essa razão que os egípcios viram a necessidade de criar um novo tipo de número: o número fracionário. Representar um número por meio de uma fração sempre foi um problema antigo da matemática, contudo, por volta de 800 d.C., os hindus encontraram uma nova forma de representar os números, surgindo assim os primeiros decimais.

Pensaram que noção decimal fosse um processo infinito, no sentido que nunca termina, como o caso de $\frac{1}{3}$ se multiplicarmos o numerador desta fração por potências sucessivas de 10 obtemos sempre o mesmo resto 1 e o processo é periódico. Muitos matemáticos definem uma Dízima Periódica como uma representação numérica, tanto decimal quanto fracionária, onde existe uma sequência finita de algarismos que se repetem indefinidamente.

\section{[1] "Etimologia do dia: Dízima Periódica}

Ela é complexa. Está sempre presente (graças às interferências de Murphy, que era amicíssimo de Pitágoras) nos resultados das divisões inexatas.

É sempre uma resposta que faz até a calculadora mais poderosa do mundo exibir uma notação científica muito parecida com um ERRO.

Ela é a Dízima Periódica. Este termo surgiu antes de Chicago Bulls existir. Antes mesmo de sua vovó descobrir a anatomia de seu vovô.

Muito antes de Carlota Joaquina fazer suas peripécias e ser chamada de "A Louca" (inclusive, foi um descendente dela que resolveu entrar para a noite e criar a balada que leva o mesmo apelido de sua ancestral).

Muito antes até mesmo de Isaac Newton tentar acertar um passarinho com estilingue, errar, acertar uma maçã e descobrir a gravidade.

Ele surgiu na idade Antiga, ainda com os egípcios: famosos escritores de epopeias matemáticas.

Nessa época, o Egito sofria constantes ataques de um povo nômade que se chamava "Périos de Dicas" - inclusive é esse o mesmo povo que descobriu a periodontia e desenvolveu suas técnicas.

Este povo tinha como estratégia de guerra atacar seus inimigos de tempos em tempos, sempre precedendo os ataques com o envio de papiros com 
inscrições ameaçadoras - o que também deu origem ao termo "periódicos" tão conhecido pelos leitores dessa forma de publicação impressa.

Durante a $4^{\mathrm{a}}$ e a $7^{\mathrm{a}}$ dinastia de imperadores desse povo, eles realizaram esses ataques. Após muita conversa em conferências com os escravos criadores de pirâmides, escribas e sacerdotes, o Egito começou a se revoltar com a submissão com que ia levando toda aquela história. Tratou então de se armar.

Com a proximidade do solstício de inverno na região, época esta em que geralmente acontecia algum ataque, o Faraó Tutan Seinmon (avô de Tutan Kamon) reuniu o topo da pirâmide social egípcia para preparar a estratégia de cerceamento de evidências de contra-ataque para o inimigo. Com isto, planejaram o que foi a precursora da tática do Cavalo de Tróia, erroneamente dita como totalmente original e inédita.

Chega o grande momento da verdade. Tropas preparadas e camufladas em cabanas subareianas (o mesmo que subterrânea, só que para o caso de areia) aguardando pela chegada do inimigo. Estamos falando agora do, até então, covarde povo egípcio e, agora, bravo e valente.

Os nômades de Périos de Dicas invadem a região. Neste mesmo momento, Tutan Seinmon sai bravamente de seu esconderijo montado em seu camelo mais veloz - outro fato histórico que marcou toda uma geração de escritores que doaram seus livros à corte portuguesa, fazendo com que chegasse às mãos do pequeno Pedro II e o motivasse a representar da mesma forma quando proclamou a independência do Brasil - e dá o sinal de guerra gritando afobada e rapidamente: "Dizima os Périos de Dicas!". Este grito foi dado quando Tutan viu 10 soldados se aproximando e, esse número também está relacionado a "decimalidade" da expressão matemática.

Nessa época, a conjugação dos verbos no imperativo era diferente de como é hoje. Por esse motivo, o verbo "dizimar" apresenta-se desta forma, em vez de "dizimem" e, pela importância histórica do ocorrido, foi mantido independentemente das flexões ocorridas normalmente na língua ao longo do tempo. 


\section{Universidade de Brasília \\ Departamento de Matemática}

Desta maneira, percebe-se que não poderia ser melhor o nome dado a esse tipo de resultado matemático, já que ele é tão complexo e amedrontador quanto o fato que originou esse nome. Então, agora, você já sabe. Matemática é coisa séria".

\section{Referências Bibliográficas:}

[1] http://melhoranedotadomundo.blogspot.com.br/2009/05/etimologiado-dia-dizima-periodica.html em 13/01/2015

[2] DÍZIMAS PERIÓDICAS - DOIS OLHARES: DO ENSINO MÉDIO E DO SUPERIOR, NASCIMENTO, A.C.; WEBER, T. C.; MERLI, R. F. 


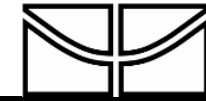 \\ Universidade de Brasília \\ Departamento de Matemática}

\section{Atividade 4 \\ Medidas de comprimento}

Nome:

Data:

Nessa atividade, responda somente as questões 1, 2, 3 e 4 utilizando caneta azul ou preta.

Em seguida, faça a correção das questões juntamente com a professora. Após a explicação responda as questões 5, 6 e 7 .

1) Você conhece alguma medida de comprimento? Quais?

2) Qual a melhor medida de comprimento para medir o tamanho da sua caneta? E para medir a altura de um prédio?

3) Você sabe fazer a conversão das unidades de medidas de comprimento?

4) A distância de sua casa até a escola é de $2,5 \mathrm{~km}$. Converta essa medida em metro $(\mathrm{m})$.

5) Converta 15 metros em quilômetros $(\mathrm{km})$.

6) Converta $23,45 \mathrm{dm}$ em hm.

7) Converta 0,1234 dam em $\mathrm{mm}$.

\section{Breve histórico:}

Com o início da construção das habitações e o desenvolvimento da agricultura, o homem viu a necessidade de efetuar medições e para isso começou a utilizar referências corporais, que seriam as primeiras medidas de comprimento como a polegada, o palmo, o pé, a jarda, a braça e o passo. 


\section{Universidade de Brasília}

Departamento de Matemática

Algumas dessas medidas (a polegada, o pé e a jarda) continuam sendo utilizadas até hoje. Os seus correspondentes em centímetros são:

$$
\begin{gathered}
1 \text { polegada }=2,54 \mathrm{~cm} \\
1 \text { pé }=30,48 \mathrm{~cm} \\
1 \text { jarda }=91,44 \mathrm{~cm} \\
1 \text { braça }=222 \mathrm{~cm} \\
1 \text { palmo }=22 \mathrm{~cm} \\
1 \text { passo }=74 \mathrm{~cm}
\end{gathered}
$$
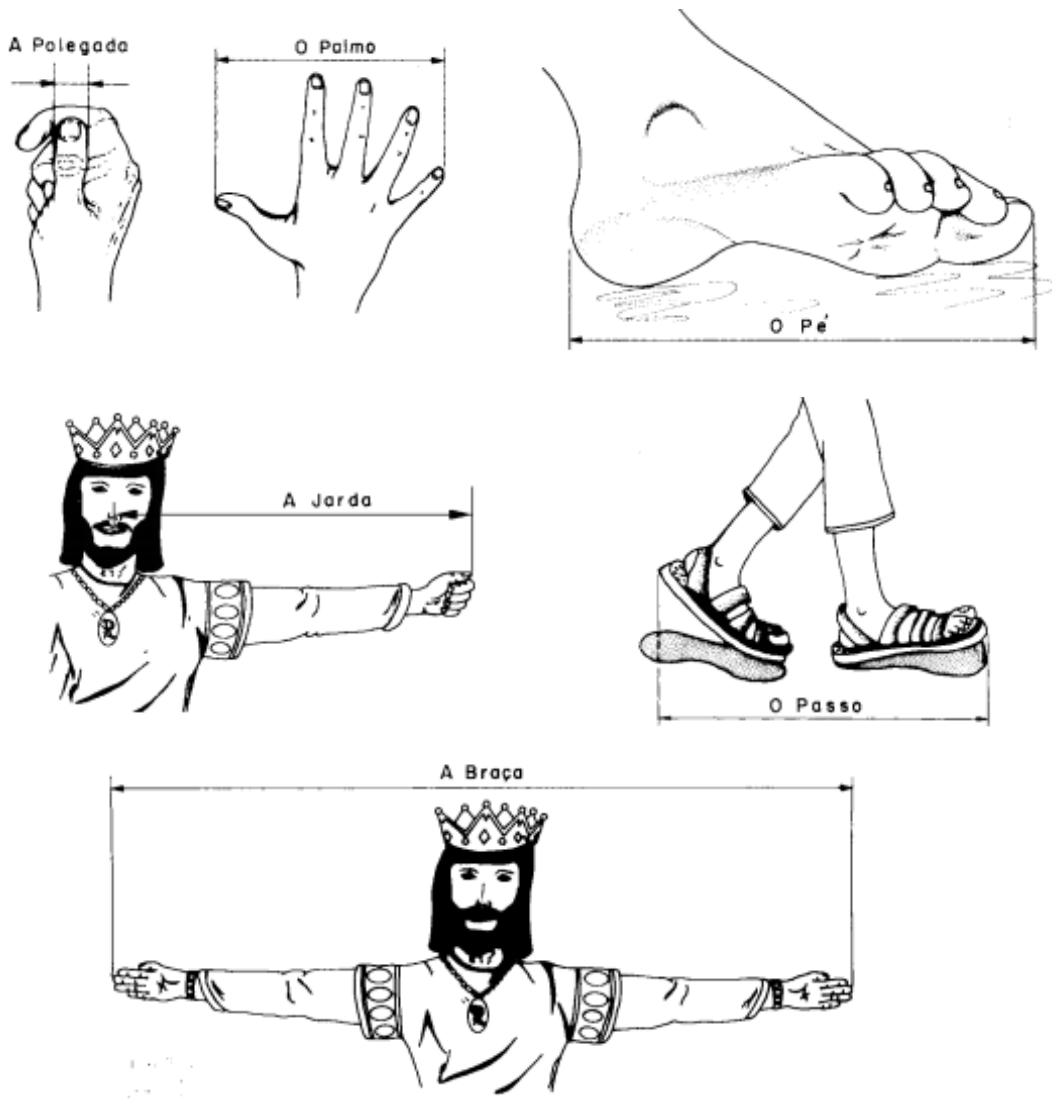

Porém, como havia tamanhos diferentes para cada uma dessas medidas, a sociedade se viu atingida por métodos arbitrários causando prejuízos e injustiças nos mais diversos aspectos. Então os egípcios, fixaram um padrão único. Passaram a usar em suas medições barras de pedra com o mesmo comprimento. Foi assim que surgiu o cúbito-padrão, há cerca de 4000 anos e com o tempo, passaram a usar barras de madeira para facilitar seu transporte. 


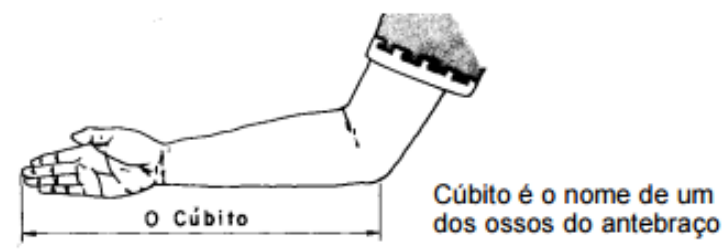

Entretanto, como cada povo tinha seus próprios padrões, algumas dificuldades ainda persistiam, prejudicando o comércio entre os povos. O cúbito sumério media $49,5 \mathrm{~cm}$, o cúbito egípcio $52,4 \mathrm{~cm}$ e o cúbito assírio mediam 54,9 $\mathrm{cm}$. A padronização das medidas aconteceu durante a Revolução francesa. $\mathrm{O}$ maior problema encontrado não era as diferentes unidades de medidas, mas os diferentes tamanhos das unidades. Mas, ao invés de simplesmente padronizar o tamanho das unidades existentes, os líderes da Assembleia Nacional Constituinte Francesa decidiram adotar um sistema de medidas completamente novo.

Em 1790, a Academia de Ciências de Paris criou uma comissão, que incluíam matemáticos, físicos, astrônomos e agrimensores que definiram que a unidade de comprimento metro deveria corresponder a uma determinada fração da circunferência da Terra e correspondente também a um intervalo de graus do meridiano terrestre, que equivale à décima milionésima parte do quadrante de um meridiano terrestre.

Em 22 de junho de 1799 foi depositado, nos Arquivos da República em Paris, dois protótipos de platina iridiada, que representam 0 metro e 0 quilograma, ainda hoje conservados no Escritório Internacional de Pesos e Medidas (Bureau International des Poids et Mesures) na França.

Em 20/05/1875, um tratado internacional conhecido como Convention du Mètre (Convenção do Metro), foi assinado por 17 Estados, estabelecendo o metro como unidade padrão de medida.

$\mathrm{Na}$ prática, a alteração de padrões de medida passou por certa resistência. Em 1826, foram feitas 32 barras-padrão na França. Em 1889, determinou-se que a barra № 6 seria o metro dos Arquivos e a de o 26 foi destinada ao Brasil. Este metro-padrão encontra-se no IPT (Instituto de Pesquisas Tecnológicas). 
$\mathrm{Na}$ França, o uso do metro só se tornou obrigatório a partir de 1. de janeiro de 1840 e, no Brasil, o sistema métrico foi adotado efetivamente só em 1938, por decreto. Até hoje ainda existem algumas medidas que são diferentes, como por exemplo, no Brasil temos o alqueire paulista $\left(24.200 \mathrm{~m}^{2}\right)$, o alqueire mineiro $\left(48.400 \mathrm{~m}^{2}\right)$ e o alqueire do Norte $\left(27225 \mathrm{~m}^{2}\right)$.

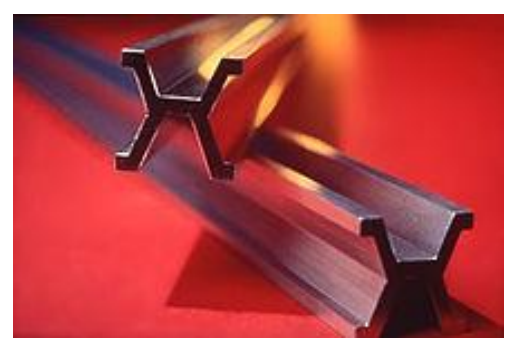

A barra de platina-irídio utilizada como protótipo do metro de 1889 a 1960.

A polegada tem sua origem na idade média onde romanos mediam com o próprio polegar. É a largura de um polegar humano regular, medido na base da unha, a qual, num ser humano adulto, é de aproximadamente $2,5 \mathrm{~cm}$.

$\mathrm{O}$ pé como medida foi usado em quase todas as culturas, e era geralmente dividido em 12 ou 10 polegadas. O primeiro padrão de medida originou-se na Suméria, onde uma definição foi gravada na estátua de Gudéia da cidade de Lagash, por volta de 2575 AC. A crença popular diz que o valor original era o comprimento do pé de um homem, mas não foi confirmado se foi utilizado o pé de algum homem específico.

No século XII, o rei Henrique I da Inglaterra fixou a jarda como a distância entre seu nariz e o polegar de seu braço estendido. Atualmente é usada no futebol americano.

\section{Referências Bibliográficas}

http://www.diaadiaeducacao.pr.gov.br/portals/pde/arquivos/2170-8.pdf em 13/01/2015

http://www.infoescola.com/matematica/unidades-de-medidas-de-comprimento/ em 16/01/2015

http://www.clubedaeletronica.com.br/Mecanica/Metrologia\%20TC-

2000/metr1.pdf em 13/04/2015 


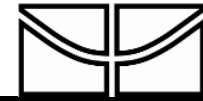 \\ Universidade de Brasília \\ Departamento de Matemática}

\section{Atividade 5}

\section{Regra de três simples}

Nome:

Data:

Nessa atividade, responda somente as questões 1, 2 e 3 utilizando caneta azul ou preta.

Em seguida, faça a correção das questões juntamente com a professora. Após a explicação responda as questões 4 e 5.

1) Você sabe utilizar a regra de três simples?

2) Um muro de 12 metros foi construído utilizando 2160 tijolos. Caso queira construir um muro de 30 metros nas mesmas condições do anterior, quantos tijolos serão necessários?

3) Uma equipe de 5 professores gastou 12 dias para corrigir as provas de um vestibular. Considerando a mesma proporção, quantos dias levariam 30 professores para corrigir essas provas?

4) Em uma panificadora são produzidos 90 pães de 15 gramas cada um. Caso queira produzir pães de 10 gramas, quantos pães iremos obter?

5) Uma usina produz 500 litros de álcool com $6000 \mathrm{~kg}$ de cana - de - açúcar. Determine quantos litros de álcool são produzidos com 15000 kg de cana.

\section{Breve histórico:}

Provavelmente, a regra de três, surgiu na Índia (alguns autores acreditam que ela foi descrita, pelo menos rudimentarmente, nos versos hindus Vedanga Jyotisa, no período de 1370 - 1150 a.C. ou no período 500 a.C. Ela aparece escrita da seguinte forma: "O resultado conhecido deve ser multiplicado pela quantidade requerida e dividido pela quantidade para a qual o resultado conhecido é dado." E entrou na Europa, através dos árabes, onde era utilizada para resolver todo tipo de problemas derivados de atividade comercial e ocupava $20 \%$ dos livros de aritmética dos mercadores da época. 
Ela foi muito usada no comércio, por vários séculos, porém como uma simples regra. O matemático indiano Brahmagupta, já no século VII d.C., usava as técnicas da regra de três. (Eis como Brahmagupta enunciava a regra: "Na regra de três, os nomes dos termos são Argumento, Fruto e Requisito. O primeiro e último termos devem ser semelhantes. Requisito multiplicado por Fruto e dividido por Argumento é o Produto".)

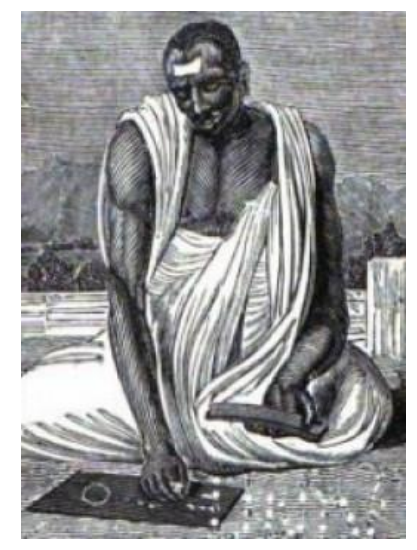

Brahmagupta

O Prof. Ralph P. Boas, da "Northwestern University", celebrou o fato dos americanos não abordarem mais o termo "rule of three" (regra de tres) em versos publicados na revista "American Mathematical Monthly" - 02/86 - pag. 115 reproduzidos a seguir:

"What has become of the rule of the three,

Simple or double, once popular pair?

Students today no longer see

Alligation or tret and tare.

O que aconteceu com a regra de três,

Simples ou composta, outrora um par tão popular?

Os estudantes de hoje não mais reconhecem

Esse antigo processo de resolução de problemas. 


\section{Universidade de Brasília \\ Departamento de Matemática}

Obs: "Alligation", "tret" e "tare" , em inglês, referem-se, de uma certa forma, a um antigo processo de resolução de problemas, nos EUA.

\section{Referências Bibliográficas:}

Revista RPM n. 9 / $2^{\circ}$ semestre 1986, publicação da Sociedade Brasileira de Matemática - num artigo do Prof. Geraldo Ávila - pag. 8 http://www.paulomarques.com.br/arq1-13.htm em 16/01/2015

http://circuitomatematica.blogspot.com.br/2010/12/regra-de-tressimples.html em 13/01/2015

http://matematicaanisio.blogspot.com.br/2011/11/origem-da-regra-detres.html em 13/01/2015

http://vims003.hubpages.com/hub/Brahmagupta-The-Mathematician\# em $23 / 04 / 2015$ 


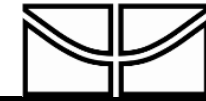 \\ Universidade de Brasília \\ Departamento de Matemática}

\section{Atividade 6 \\ $\underline{\text { Teorema de Pitágoras }}$}

Nome:

Data:

Nessa atividade, responda somente as questões 1, 2 e 3 utilizando caneta azul ou preta.

Em seguida, faça a correção das questões juntamente com a professora. Após a explicação responda as questões 4 e 5.

1) Você conhece o Teorema de Pitágoras? Se sim, enuncie esse famoso teorema.

2) Quais são os nomes dos lados de um triângulo retângulo?

3) Se um triângulo possui catetos medindo $12 \mathrm{~cm}$ e $5 \mathrm{~cm}$, quanto mede a hipotenusa?

4) (UERJ) Millôr Fernandes, em uma bela homenagem à Matemática, escreveu um poema do qual extraímos o fragmento abaixo:

Às folhas tantas de um livro de Matemática,

um Quociente apaixonou-se um dia doidamente por uma Incógnita.

Olhou-a com seu olhar inumerável

e viu-a do ápice à base: uma figura ímpar;

olhos rombóides, boca trapezóide,

corpo retangular, seios esferóides.

Fez da sua uma vida paralela à dela, até que se encontraram no Infinito.

"Quem és tu?" - indagou ele em ânsia radical.

"Sou a soma dos quadrados dos catetos.

Mas pode me chamar de hipotenusa."

(Millôr Fernandes. Trinta Anos de Mim Mesmo.) 
A Incógnita se enganou ao dizer quem era. Para atender ao Teorema de Pitágoras, deveria dar a seguinte resposta:
A) "Sou a soma dos catetos. Mas pode me chamar de hipotenusa."
B) "Sou o quadrado da soma dos catetos. Mas pode me chamar de hipotenusa."
C) "Sou o quadrado da soma dos catetos. Mas pode me chamar de quadrado da hipotenusa."
D) "Sou a soma dos quadrados dos catetos. Mas pode me chamar de quadrado da hipotenusa."

5) Uma escada medindo 4 metros tem uma de suas extremidades apoiada no topo de um muro, e a outra extremidade dista 2,4 $\mathrm{m}$ da base do muro. A altura desse muro é:
A) $2,3 \mathrm{~m}$
B) $3,0 \mathrm{~m}$
C) $3,2 \mathrm{~m}$
D) $3,8 m$

\section{Breve histórico:}

Pitágoras foi um importante matemático e filósofo grego. Nasceu no ano de 570 a .C na ilha de Samos, na região da Ásia Menor (Magna Grécia). Provavelmente, morreu em 497 ou 496 a.C em Metaponto (região sul da Itália). Com 18 anos de idade, Pitágoras já conhecia e dominava muitos conhecimentos matemáticos e filosóficos da época. Através de estudos astronômicos, afirmava que o planeta Terra era esférico e suspenso no Espaço (ideia pouco conhecida na época). Recebeu muita influência científica e filosófica dos filósofos gregos Tales de Mileto, Anaximandro e Anaxímenes.

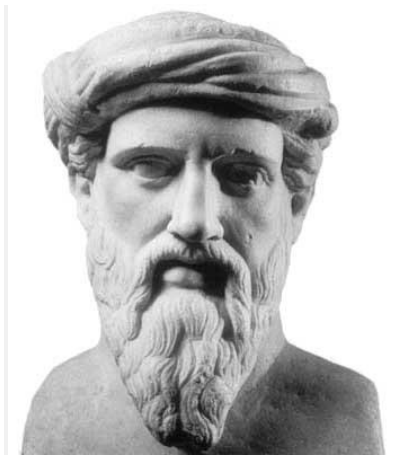




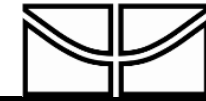 \\ Universidade de Brasília \\ Departamento de Matemática}

Enquanto visitava o Egito, impressionado com as pirâmides, desenvolveu o famoso Teorema de Pitágoras. De acordo com este teorema é possível calcular o lado de um triângulo retângulo, conhecendo os outros dois. Desta forma, ele conseguiu provar que a soma dos quadrados dos catetos é igual ao quadrado da hipotenusa. Conta a lenda que Pitágoras, ao olhar para o chão onde apareciam desenhos verificou, por composição e decomposição de figuras, uma propriedade de todos os triângulos retângulos: a área de um quadrado construído sobre a hipotenusa (lado oposto ao ângulo reto) de um triângulo retângulo é igual à soma das áreas dos quadrados construídos sobre os catetos (os outros dois lados).

Atribuem-se notáveis descobertas a Pitágoras, tais como o sistema de numeração decimal, proporções aritméticas, tabelas de multiplicação e a demonstração do teorema que leva o seu nome.

Há uma lenda que conta que Pitágoras ofereceu aos deuses mil bois como agradecimento, por ter descoberto a demonstração do referido teorema.

Para os estudos futuros da Matemática, sua influência foi enorme, pois foi um dos grandes construtores da base dos conhecimentos matemáticos, geométricos e filosóficos que temos atualmente.

\section{Referências Bibliográficas:}

http://www.educ.fc.ul.pt/icm/icm99/icm25/pitagoras/dirhpitagoras.htm em $16 / 01 / 2015$

http://www.suapesquisa.com/pesquisa/pitagoras.htm em 16/01/2015 


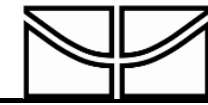 \\ Universidade de Brasília \\ Departamento de Matemática}

\section{Atividade 7}

\section{Ângulo e Transferidor}

Nome:

Data:

Nessa atividade, responda somente as questões 1 a 6 utilizando caneta azul ou preta.

Em seguida, faça a correção das questões juntamente com a professora. Após a explicação responda as questões 7 e 8.

1. Você sabe utilizar um transferidor?

2. Você sabe o que é um ângulo?

3. Quais são os tipos de ângulo que você conhece?

4. Utilizando o transferidor, determine a medida e classifique os seguintes ângulos:

5. a)

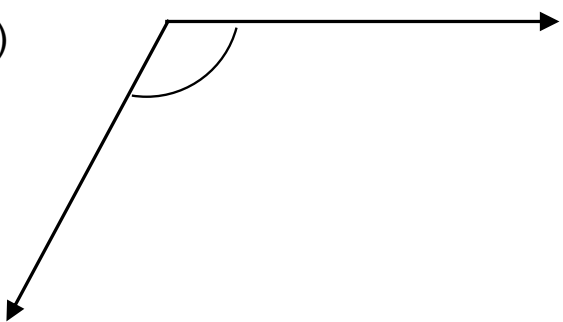

b)

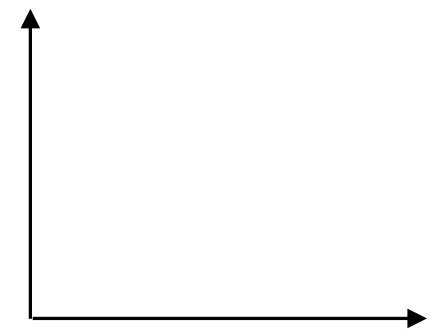

Medida:

Medida:

Classificação:

Classificação:

6. Com o auxílio de um transferidor construa um ângulo de 70․

7. Com o auxílio de um transferidor construa um ângulo de 94ํ․

8. Utilizando o transferidor, determine a medida e classifique os seguintes ângulos:

a)

c)
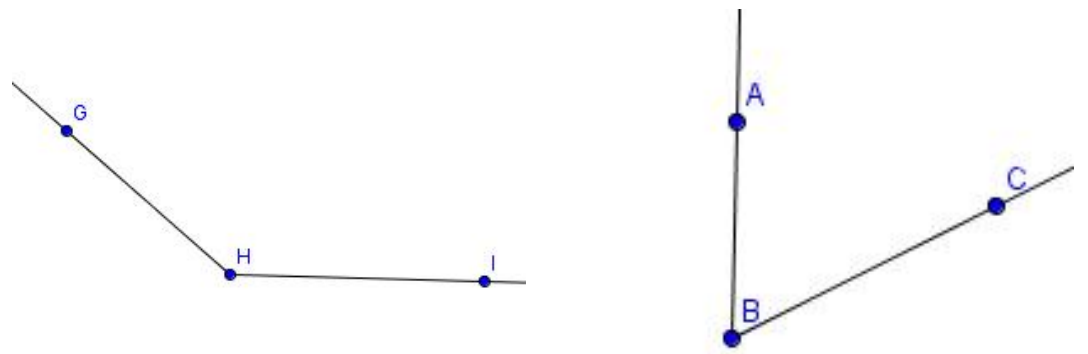
Medida:

Classificação:

b)

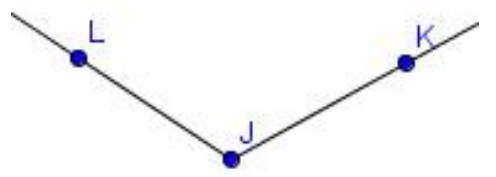

Medida:

Classificação:
Medida:

Classificação:

d)

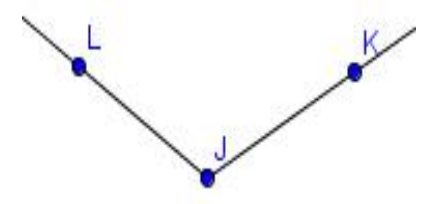

Medida:

Classificação:

\section{Breve histórico:}

Acredita-se que foi, nos 18 anos em que Galileu Galilei trabalhou na República de Pádua (desde 1592), vivendo com um salário considerado bom e vivendo num ambiente de liberdade intelectual, que ele inventou uma régua para cálculos, um transferidor, desenhou fortificações e máquinas para o cerco das cidades e pontes.

A tumba de um antigo arquiteto conhecido como Kha, foi descoberta intacta em 1906, perto do Vale dos Reis. Essa tumba continha vários objetos, onde um deles era um dispositivo de nivelamento que se assemelhava a um esquadro moderno. Também continha um objeto que muitos arqueólogos não sabiam do que se tratava e que por mais de 100 anos foi rotulado como algo que provavelmente tinha sido usado para prender mais de um instrumento de nivelamento ou uma escala de equilíbrio.

Mas, Amelia Sparavigna, física italiana da Politécnica de Turim, sugeriu que o objeto era um primeiro exemplar mundial de um transferidor. Ela acredita que os números codificados nas inscrições da superfície do objeto se assemelhavam a uma bússola, com 16 pétalas espaçadas por uma forma circular em ziguezague, com 36 cantos e era usado para medir a inclinação de 
certos ângulos. Ela acreditava que o objeto era um transferidor que tinha duas escalas, uma com base em frações egípcias e outra baseada em decanos.

Mas a sugestão de Sparavigna não foi aceita por muitos e uma especialista em arquitetura egípcia da Universidade de Cambridge, Kate Spence, acredita que o objeto é apenas decorativo, uma vez que os instrumentos de medição egípcios tinham sempre muita precisão e esse objeto da tumba de Kha não era tão preciso assim.

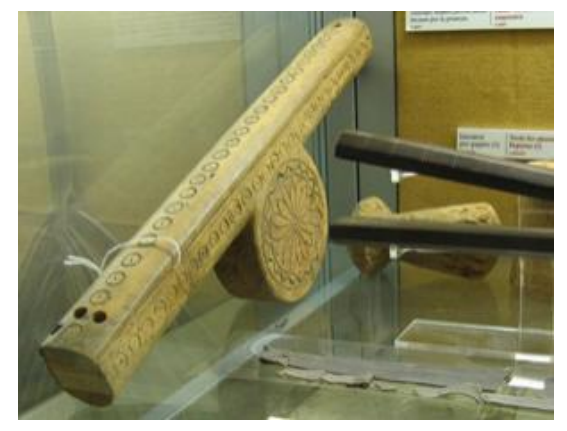

Objeto estranho encontrado na tumba de Kha

Quanto aos ângulos, por volta de 3000 a.C., na Mesopotâmia (que hoje corresponde ao Iraque, Kuwait e parte da Síria), os sábios que viviam nessa época dividiram um círculo em 12 partes iguais, dando origem aos 12 signos do Zodíaco. E ao dividir cada uma dessas partes em 30 partes iguais, chegou-se a medida do grau, que corresponde a $\frac{1}{360}$ de um círculo.
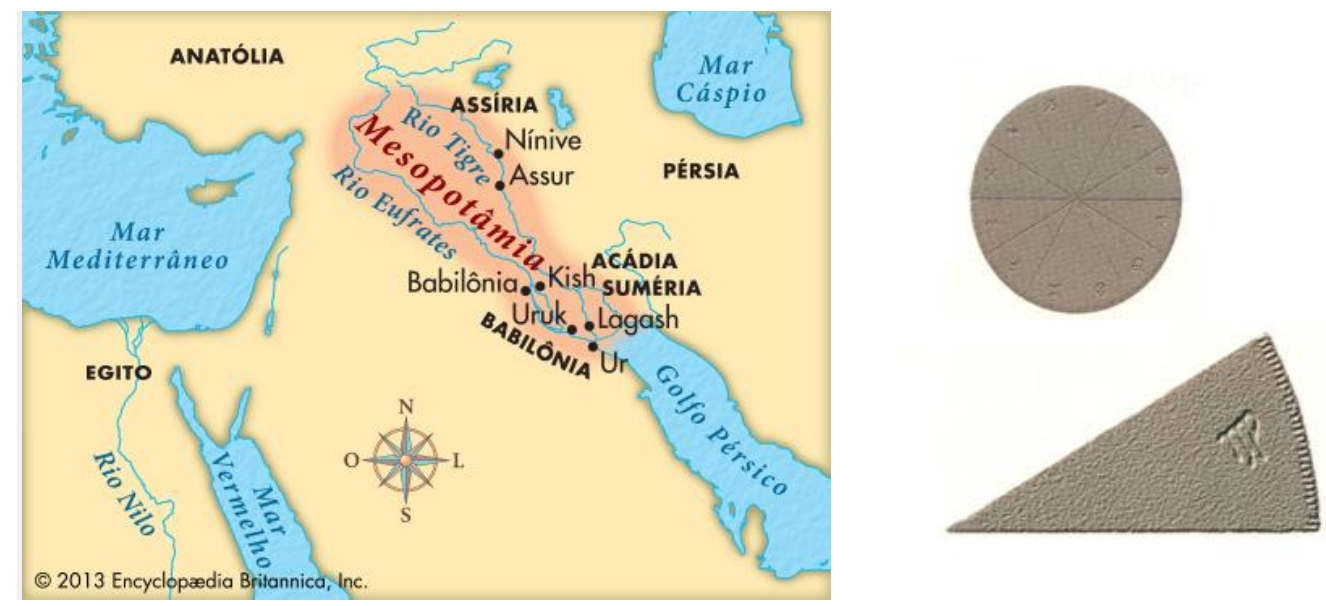


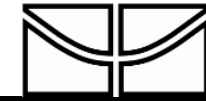 \\ Universidade de Brasília \\ Departamento de Matemática}

Acredita-se que a ideia de ângulo agudo, ângulo entre $0^{\circ}$ e $90^{\circ}$, é bem antiga, pois analisando as pontas das flechas dos povos da idade da pedra, passando pela idade dos metais e chegando até os nossos dias percebe-se que as pontas seguiam um formato perpendicular, pois a ponta aguda dava mais direção e penetrava com mais facilidade no animal a ser caçado.

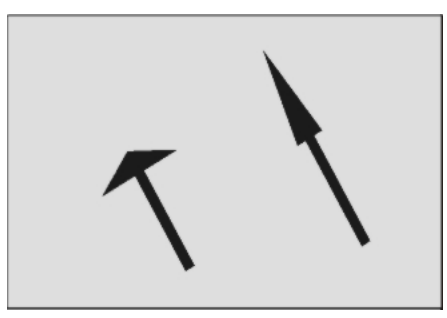

As primeiras ideias concretas a respeito de ângulo são bem recentes e são encontradas nos gregos a partir de Tales (séc. VI a.C.) e em Euclides (séc. III a.C.). Para Euclides "Ângulo plano é a inclinação de duas linhas, que se tocam em uma superfície plana. Quando as linhas são retas, o ângulo é denominado de retilíneo."

Hoje a definição utilizada para ângulo é a região de um plano determinada pelo encontro de duas semirretas que possuem uma origem em comum, chamada vértice do ângulo.

\section{Referências Bibliográficas:}

http://antigoegito.org/artefato-egipcio-pode-ter-sido-o-primeirotransferidor-do-mundo/ em 04/05/2015

http://www.estudarmatematica.pt/2014/08/historia-dos-angulos.html em 04/05/2015

http://www.matematicahoje.com.br/telas/autor/artigos/artigos_publicados. asp?aux=SemiRetas em 04/05/2015 


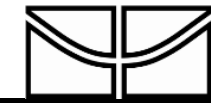 \\ Universidade de Brasília \\ Departamento de Matemática}

\section{Atividade 8}

\section{Compasso}

Nome:

Data:

Nessa atividade, responda somente as questões 1 a 3 utilizando caneta azul ou preta.

Em seguida, faça a correção das questões juntamente com a professora. Após a explicação responda as questões 4 a 7 .

1. Você sabe utilizar um compasso?

2. Faça uma circunferência de raio $3 \mathrm{~cm}$.

3. Determine a reta mediatriz e o ponto médio do segmento $A B$.

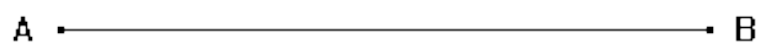

4. Determine o centro da circunferência dada a seguir.

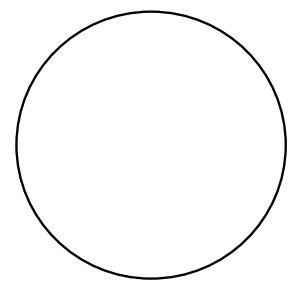

5. Com o auxílio de um compasso, transporte o ângulo AÔB para a semirreta O'r.
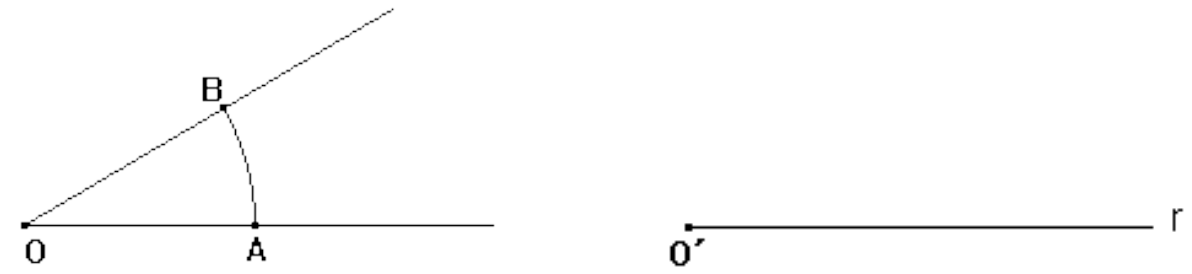

6. Efetue a operação graficamente, com o auxílio de um compasso. 


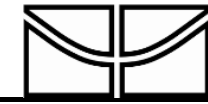 \\ Universidade de Brasília \\ Departamento de Matemática}
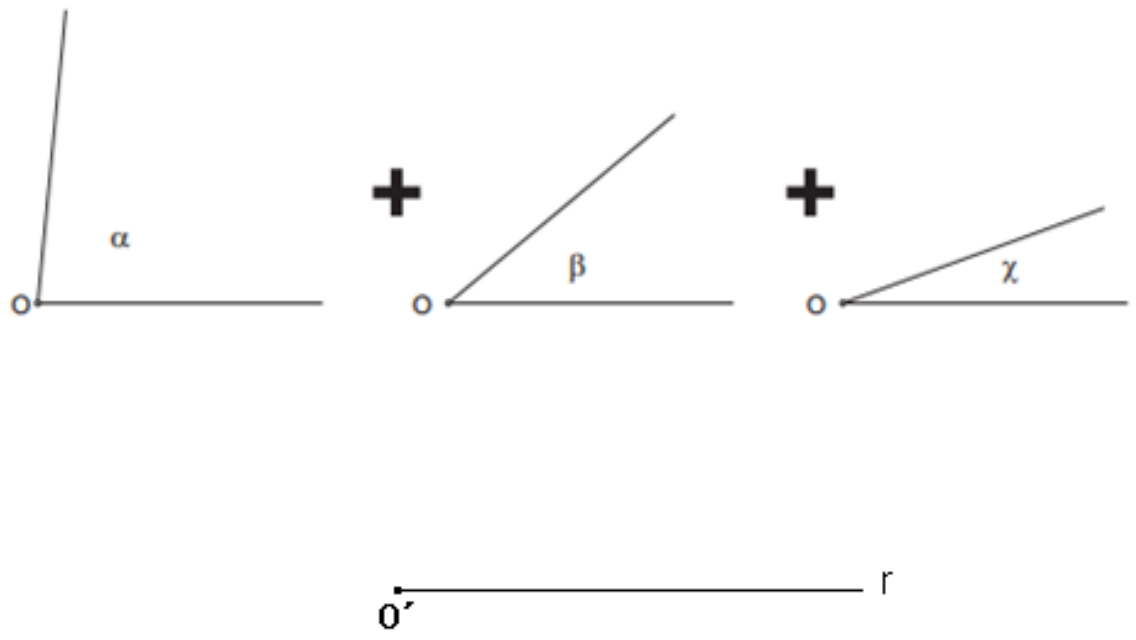

1. Por um ponto $P$ fora da reta, trace uma reta perpendicular a reta.

$\cdot \mathrm{P}$

\section{Breve histórico:}

Por volta de 3000 a.C, por meio de duas estacas cravadas na terra, os sumérios e os egípcios assinalavam um segmento de reta. Em seguida prendiam e esticavam cordas que funcionavam à maneira de compassos: dois arcos de circunferência se cortavam e determinavam dois pontos que, unidos, seccionavam perpendicularmente a outra reta, formando os ângulos retos.

Por volta de 500 a.C., as primeiras universidades foram fundadas na Grécia. A curiosidade aumentava e a busca pelos livros sobre Geometria se intensificou. Um compasso logo substituiu a corda e a estaca para traçar círculos, e o novo instrumento foi incorporado ao arsenal dos geômetras.

Em meados do século XV, o compasso parabólico foi inventado por Leonardo da Vinci, que nasceu em Vinci, próximo a Florença, na Itália, em 15 de abril de 1452 . 


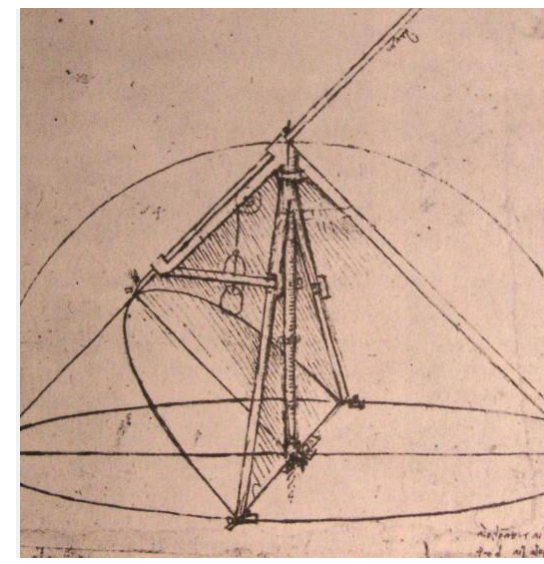

Compasso parabólico

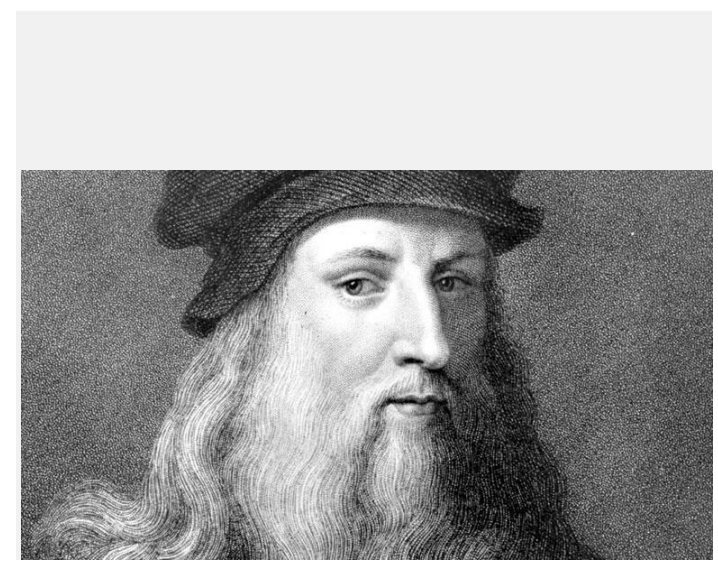

Leonardo da Vinci

No século XVI, durante 8 anos de sua vida, Galileu se dedicou a um projeto de aperfeiçoamento de um objeto já existente e o transformou em um dispositivo mecânico de cálculo, chamado de compasso "proporcional", mas Galileu chamava-o de compasso geométrico e militar. Ele usava esse instrumento para medir ângulos e fazer cálculos, pois era da forma em que seus dois braços achatados, que mediam cerca de $30 \mathrm{~cm}$ de comprimento por $2,5 \mathrm{~cm}$ de largura, onde em seus braços tinham várias regras geométricas escritas. Ganhou bastante dinheiro ensinando as pessoas a usar o compasso.

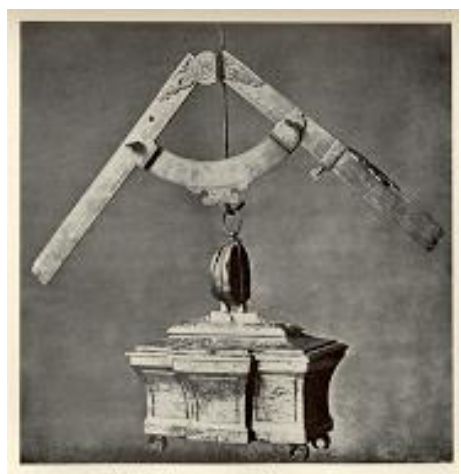

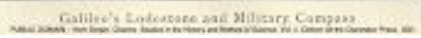

Compasso geométrico 

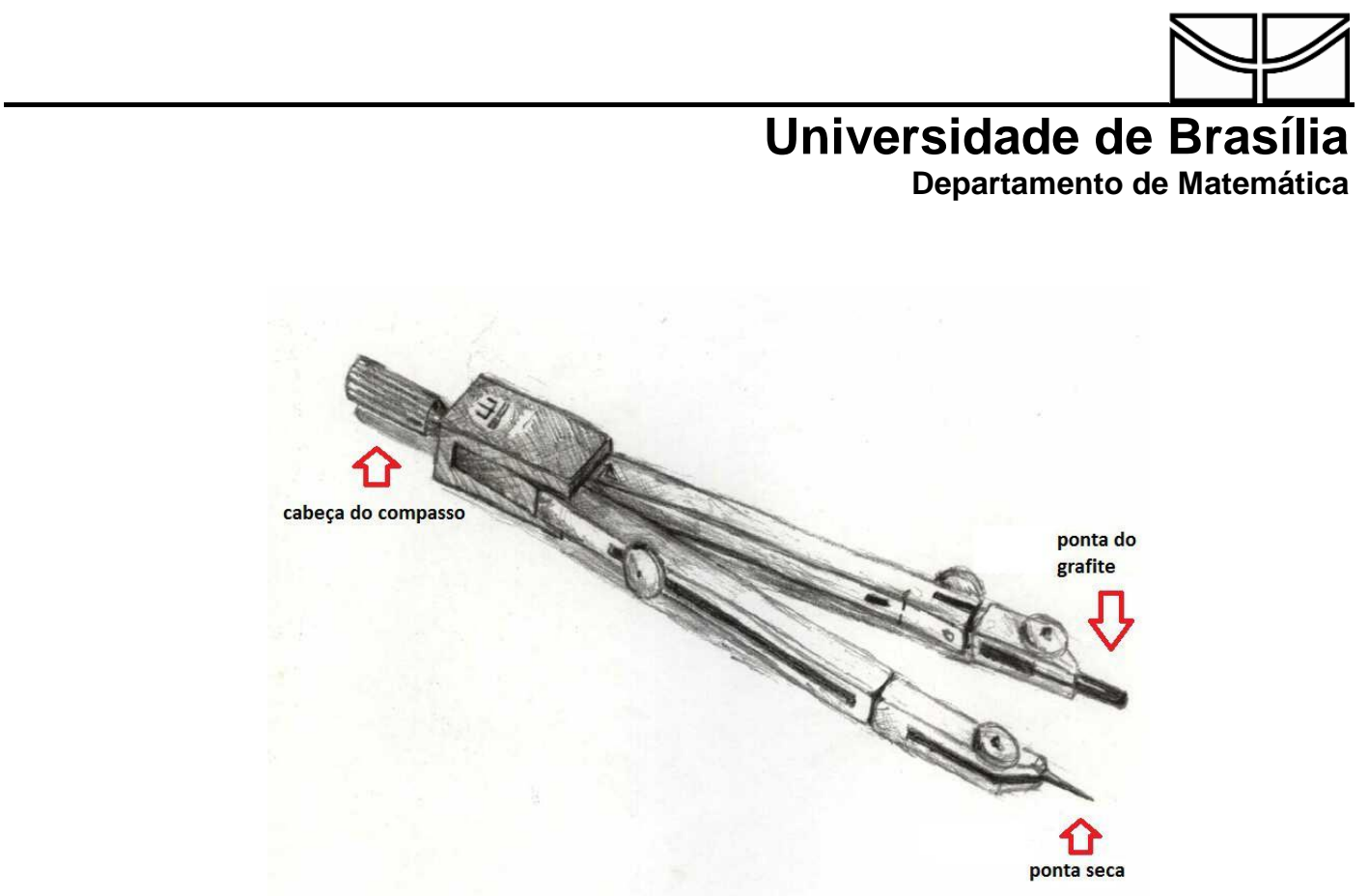

Compasso nos dias atuais

\section{Referências Bibliográficas:}

http://www.somatematica.com.br/geometria.php em 16/05/2015

http://www.sabercultural.com/template/especiais/Leonardo-da-Vinci-

Velhice.html em 16/05/2015

http://g-galilei.blogspot.com.br/p/instrumentos.html em 16/05/2015 


\section{$\$$ \\ Universidade de Brasília \\ Departamento de Matemática}

\section{Atividade 9}

\section{Trigonometria}

Nome:

Data:

Nessa atividade, responda somente as questões 1 e 2 utilizando caneta azul ou preta.

Em seguida, faça a correção das questões juntamente com a professora. Após a explicação responda as questões 3 e 4.

1. Você sabe resolver questões utilizando as razões trigonométricas?

2. Quais são os lados de um triângulo retângulo e quais são as razões entre seus lados?

3. Nos triângulos retângulo a seguir, determine as medidas de $x$ e $y$ indicadas (Use: $\operatorname{sen} 65^{\circ}=0,91 ; \cos 65^{\circ}=0,42 ; \operatorname{tg} 65^{\circ}=2,14$ )

a)

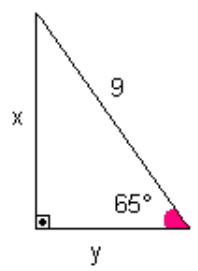

b)

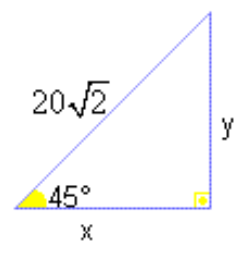

c)

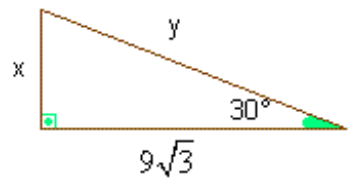

4. Considerando o triângulo retângulo $A B C$, determine as medidas a e b indicadas.

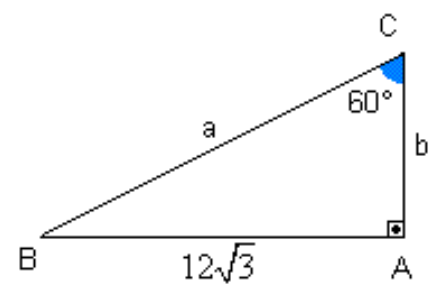




\section{Breve histórico:}

Não se tem certeza da origem da trigonometria, mas sabe-se que o início do seu desenvolvimento se deu devido a problemas gerados pela Astronomia e Navegações, por volta do século IV ou $V$ a.C., com os egípcios e babilônios. A palavra trigonometria trata do estudo das relações entre os lados e os ângulos de um triângulo, pois tri significa três, gono significa ângulo e metria significa medida. É possível encontrar problemas envolvendo cotangente no Papiro Rhind e uma notável tábua de secantes na tábula cuneiforme babilônica Plimpton 322.

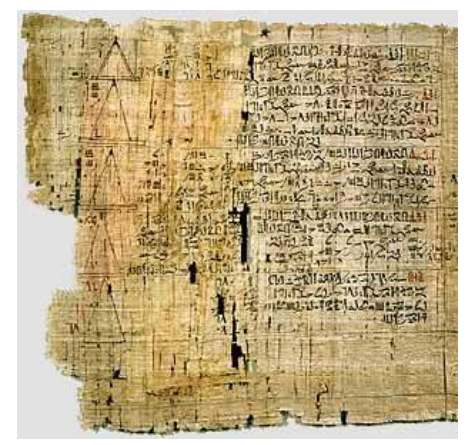

Papiro Rhind

Por volta de 180 a 125 a.C., o astrônomo Hiparco de Nicéia, foi chamado de "o pai da trigonometria", pois fez um tratado em doze livros, na segunda metade do século II a.C., em que se ocupou da construção do que deve ter sido a primeira tabela trigonométrica, isto é, uma tábua de cordas, com os valores dos seus arcos para uma série de ângulos, fazendo cálculos para usá-los em seus estudos de Astronomia. Usando os conhecimentos dos babilônicos, introduziu a divisão da circunferência em 360ํㅡa Grécia.

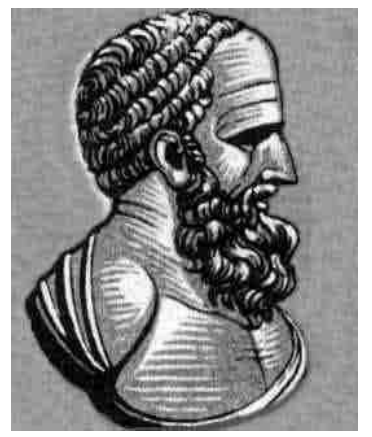

Hiparco de Nicéia

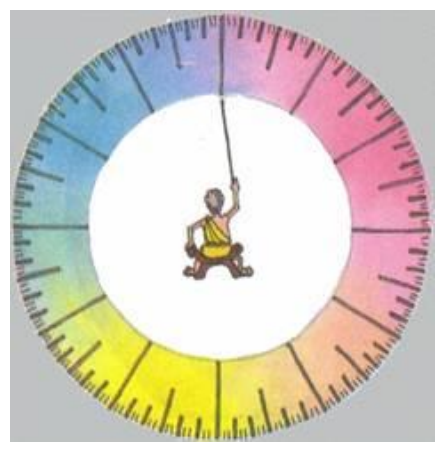

Divisão da circunferência em 360ํำ 
Originados pelos problemas relativos à Astronomia, surgiram os conceitos de seno e cosseno, enquanto que, ao que parece, o conceito de tangente surgiu da necessidade de calcular alturas e distâncias.

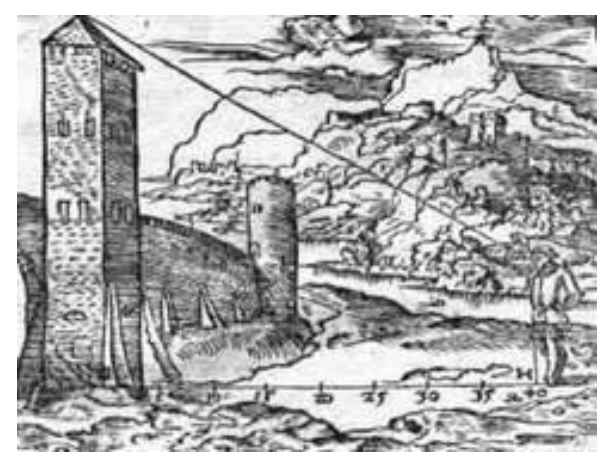

O nome seno, do latim sinus, que significa seio, volta, curva, cavidade. Mas, na verdade, sinus é a tradução latina da palavra árabe jaib, que significa dobra, bolso ou prega de uma vestimenta que não tem nada a ver com o conceito matemático de seno. Trata-se de uma tradução defeituosa que dura até hoje. Hoje seno é a razão entre o cateto oposto e a hipotenusa: $\operatorname{sen} \boldsymbol{x}=\frac{\boldsymbol{c o}}{\boldsymbol{H I P}}$

A palavra cosseno surgiu somente no século $\mathrm{XVII}$, como sendo o seno de um ângulo complementar. Hoje cosseno é a razão entre o cateto adjacente e a hipotenusa: $\cos \boldsymbol{x}=\frac{\boldsymbol{C A}}{\boldsymbol{H I P}}$

Por sua vez, a função tangente era a antiga função sombra, que tinha ideias associadas a sombras projetadas por uma vara colocada na horizontal. A variação na elevação do Sol causava uma variação no ângulo que os raios solares formavam com a vara e, portanto, modificava o tamanho da sombra. Hoje a tangente é a razão entre o cateto oposto e o cateto adjacente: $\boldsymbol{t} \boldsymbol{g} \boldsymbol{x}=\frac{\boldsymbol{c o}}{\boldsymbol{C A}}$

\section{Referências Bibliográficas:}

http://ecalculo.if.usp.br/historia/historia_trigonometria.htm em 04/05/2015 http://www.esaas.com/grupos/matematica/estagios/Paginas/HiparcoDeNi ceia.htm em 04/05/2015 


\section{Atividade 10 \\ Construcão do Teodolito e aplicacão dos conceitos de Trigonometria}

Nome: Data:

Nessa atividade iremos finalizar o projeto com a construção e utilização do teodolito.

\section{Materiais necessários:}

1 trena; 1 rolo de durex; 1 canudo; 1 transferidor; 1 rolo de barbante; 1 pedra; tabela de razões trigonométricas.

\section{Modo de fazer:}

Passo 1: Cole o canudo paralelo ao eixo do transferidor com o durex.

Passo 2: Em seguida prenda o barbante cuidadosamente perpendicular ao eixo imaginário que passa pelo ponto zero.

Passo 3: Amarre a pedra ao final do barbante.

Passo 4: Pronto! O seu teodolito está pronto.

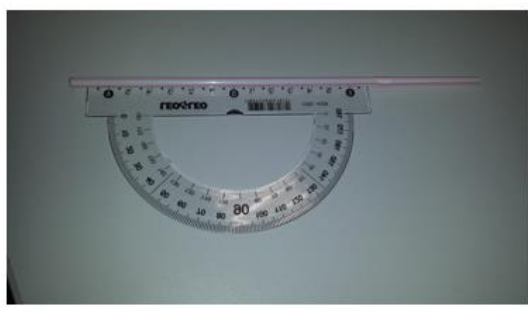

Passo 1

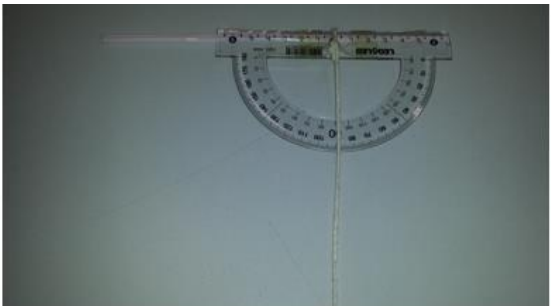

Passo 2

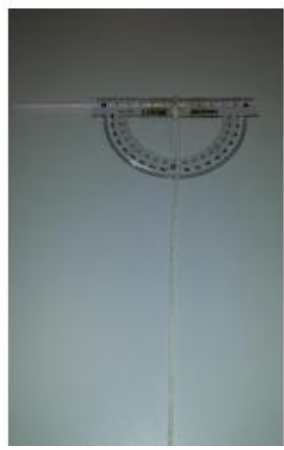

Passo 3

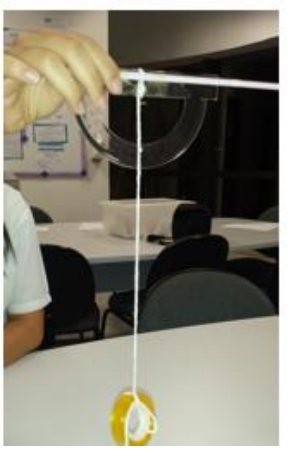

Passo 4 


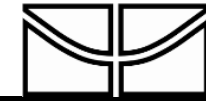 \\ Universidade de Brasília \\ Departamento de Matemática}

Para um melhor desenvolvimento da atividade, meça com a trena quantos passos você consegue dar em $1 \mathrm{~m}$ e em $2 \mathrm{~m}$ e escreva a sua altura:

$1 \mathrm{~m}=$ passos

$2 \mathrm{~m}=$ passos

Altura $=$

Pergunta 1: Utilizando o teodolito determine a altura do prédio $A$.

- Distância do ponto fixo ao prédio em passos: (depois determine essa distância em metros):

- $\quad$ Ângulo visualizado no teodolito:

- $\quad$ Cálculo da altura do prédio:

Pergunta 2: Utilizando o teodolito, qual a altura do prédio B?

- Distância do ponto fixo ao prédio em passos: (depois determine essa distância em metros):

- Ângulo visualizado no teodolito:

- Cálculo da altura do prédio:

Pergunta 3: Utilizando o teodolito, qual a altura do prédio $C$ ?

- Distância do ponto fixo ao prédio em passos: (depois determine essa distância em metros):

- $\quad$ Ângulo visualizado no teodolito:

- Cálculo da altura do prédio:

\section{Breve histórico:}

Teodolito é um instrumento óptico utilizado para medir ângulos, tanto horizontais quanto verticais, em medidas diretas e indiretas de distâncias com o objetivo de facilitar o cálculo de distâncias e alturas. O teodolito é empregado na topologia e na Geodésia, sendo ainda usado na engenharia. 


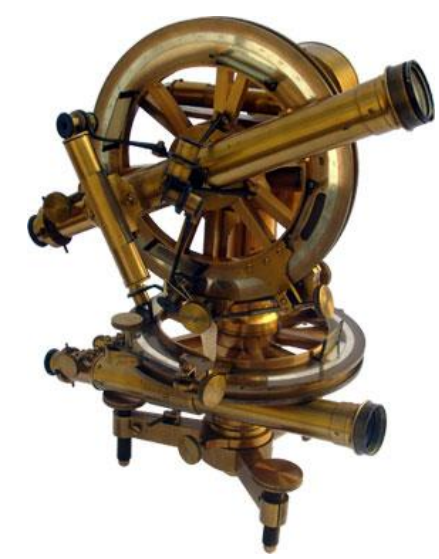

Figura 1 - Teodolito repetidor feito em bronze do século XIX (em exposição no MAST)

O primeiro teodolito contendo quatro parafusos niveladores foi construído por Jonathan Sisson, em 1720. Mas, em 1835, Ignácio Porro, inventor de instrumentos ópticos, contribuiu com o aprimoramento do teodolito acoplando o telescópio. Ao longo dos anos, o teodolito foi sendo transformado e a ele agregados sistemas e mecanismos que o tornaram mais preciso em suas medições.

Em geral, junto do teodolito é usada uma bússola para medir os ângulos formados pela posição no terreno em que está sendo realizado o levantamento topográfico/geodésico, com a direção do meridiano magnético.

Alguns teodolitos antigos possuíam a bússola acoplada em sua estrutura, como é o caso do teodolito-trânsito.

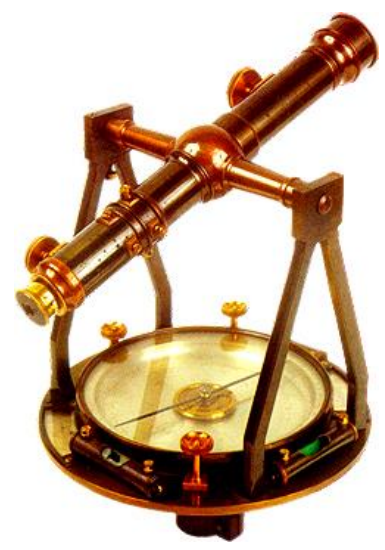

Figura 2 - Teodolito trânsito (em exposição no MAST) 
Nas explorações do território brasileiro e demarcação de limites, o teodolito foi muito utilizado na demarcação do Planalto Central do Brasil, em 1892, e pela Comissão de Limites entre Brasil e Bolívia.

O teodolito repetidor selecionado para compor o multimídia para a exposição de longa duração do museu foi doado ao Observatório Nacional em 1862 pelo Conde Prados e hoje faz parte do acervo do museu.

Este instrumento foi utilizado pela Comissão de Pernambuco durante a Observação da Passagem de Vênus pelo disco solar, em 1882, e participou da Exposição Internacional do Centenário da Independência do Brasil, em 1922, realizada no Palácio dos Estados, no Rio de Janeiro.

Atualmente, tem-se o teodolito eletrônico que é mais leve e fácil para transportar, além de ser capaz de realizar medições com maior precisão e possuir um dispositivo com ótica de alto rendimento e facilidade de utilização. Além disso, a ele podem ser acoplados outros equipamentos de medição como o distanciômetro eletrônico ou trena eletrônica.

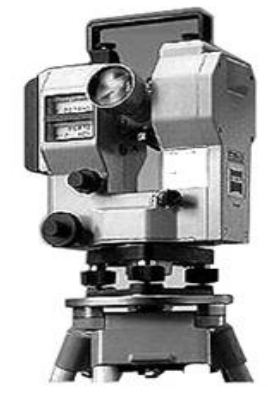

Figura 3 - Teodolito eletrônico

A estação total é um outro tipo de equipamento moderno utilizado na medida de ângulos e distâncias. Esse instrumento é uma junção do teodolito eletrônico digital com o distanciômetro eletrônico.

As estações totais são usadas em qualquer tipo de levantamento topográfico ou geodésico. Alguns modelos de estação total são robotizados e é o operador quem segura o prisma refletor e controla a máquina via controle remoto, a partir do ponto observado. Esse tipo de equipamento é usado principalmente em trabalhos de monitoramento de obras, medição de deformações e deslocamentos de terras. 


\section{Universidade de Brasília \\ Departamento de Matemática}

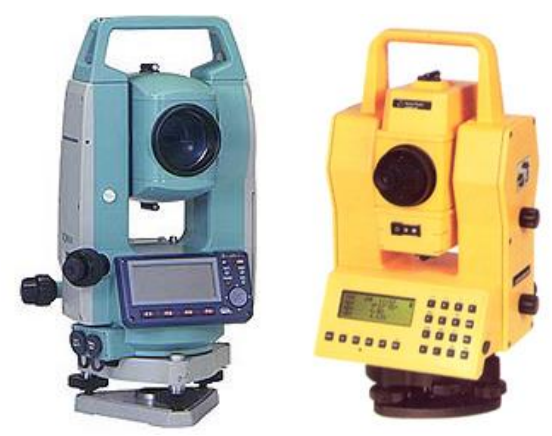

Figura 4 - Estação total

\section{Referências Bibliográficas:}

*Museu de Astronomia, MAST, disponível em

http://www.mast.br/multimidia_instrumentos/teodolito_funcao.html acessado em $15 / 06 / 15$

*Utilização do Geogebra na construção de instrumentos - Teodolito, por Esther Zilkha, disponível em:

http://www.impa.br/opencms/pt/ensino/downloads/PROFMAT/trabalho_c onclusao_curso/2014/esther_zilkha.pdf acessado em 15/06/15

\begin{tabular}{|c|c|c|c|c|c|c|c|}
\hline \multicolumn{8}{|c|}{ Tabela de razôes trigonométricas } \\
\hline Ângulo & Seno & Cosseno & Tangente & Ângulo & Seno & Cosseno & Tangen \\
\hline $1^{\circ}$ & 0,0175 & 0,9998 & 0.0175 & $46^{\circ}$ & 0.7193 & 0.6947 & 1.0355 \\
\hline $2^{\circ}$ & 0.0349 & 0.9994 & 0.0349 & $47^{\circ}$ & 0,7314 & 0.6820 & 1.0724 \\
\hline $3^{\circ}$ & 0,0523 & 0.9986 & 0,0524 & $48^{\circ}$ & 0.7431 & 0,6691 & 1.1106 \\
\hline $4^{\circ}$ & 0,0698 & 0,9976 & 0.0699 & $49^{\circ}$ & 0,7547 & 0,6561 & 1.1504 \\
\hline $5^{\circ}$ & 0.0872 & 0.9962 & 0.0875 & $50^{\circ}$ & 0.7660 & 0.6428 & 1.1918 \\
\hline $6^{\circ}$ & 0.1045 & 0.9945 & 0.1051 & $51^{\circ}$ & 0.7771 & 0.6293 & 1.2349 \\
\hline $7^{\circ}$ & 0,1219 & 0,9925 & 0,1228 & $52^{\circ}$ & 0,7880 & 0,6157 & 1.2799 \\
\hline $8^{\circ}$ & 0.1392 & 0.9903 & 0.1405 & $53^{\circ}$ & 0.7986 & 0,6018 & 1.3270 \\
\hline $9^{\circ}$ & 0.1564 & 0,9877 & 0,1584 & $54^{\circ}$ & 0,8090 & 0,5878 & 1.3764 \\
\hline $10^{\circ}$ & 0.1736 & 0,9848 & 0.1763 & $55^{\circ}$ & 0.8192 & 0.5736 & 1.4281 \\
\hline $11^{\circ}$ & 0.1908 & 0.9816 & 0,1944 & $56^{\circ}$ & 0.8290 & 0.5592 & 1.4826 \\
\hline $12^{\circ}$ & 0.2079 & 0.9781 & 0.2126 & $57^{\circ}$ & 0.8387 & 0.5446 & 1.5399 \\
\hline $13^{\circ}$ & 0,2250 & 0,9744 & 0,2309 & $58^{\circ}$ & 0.8480 & 0.5299 & 1.6003 \\
\hline $14^{\circ}$ & 0,2419 & 0.9703 & 0.2493 & $59^{\circ}$ & 0,8572 & 0,5150 & 1.6643 \\
\hline $15^{\circ}$ & 0.2588 & 0.9659 & 0.2679 & $60^{\circ}$ & 0.8660 & 0,5000 & 1.7321 \\
\hline $16^{\circ}$ & 0.2756 & 0.9613 & 0,2867 & $61^{\circ}$ & 0.8746 & 0.4848 & 1.8040 \\
\hline $17^{\circ}$ & 0.2924 & 0.9563 & 0.3057 & $62^{\circ}$ & 0.8829 & 0,4695 & 1,8807 \\
\hline $18^{\circ}$ & 0.3090 & 0.9511 & .3249 & $63^{\circ}$ & 0,8910 & 0,4540 & 1,9626 \\
\hline $19^{\circ}$ & 0.3256 & 0.9455 & 0.3443 & $64^{\circ}$ & 0,8988 & 0,4384 & 2.0503 \\
\hline $20^{\circ}$ & 0.3420 & 0.9397 & 0.3640 & $65^{\circ}$ & 0.9063 & 0,4226 & 2,1445 \\
\hline $21^{\circ}$ & 0.3584 & 0.9336 & 0.3839 & $66^{\circ}$ & 0,9135 & 0,4067 & 2.2460 \\
\hline $22^{\circ}$ & 0.3746 & 0,9272 & 0,4040 & $67^{\circ}$ & 0,9205 & 0,3907 & 2.3559 \\
\hline $23^{\circ}$ & 0,3907 & 0.9205 & 0.4245 & $68^{\circ}$ & 0.9272 & 0.3746 & 2.4751 \\
\hline $24^{\circ}$ & 0,4067 & 0.9135 & 0.4452 & $69^{\circ}$ & 0,9336 & 0,3584 & 2.6051 \\
\hline $25^{\circ}$ & 0.4226 & 0.9063 & 0.4663 & $70^{\circ}$ & 0,9397 & 0,3420 & 2.7475 \\
\hline $26^{\circ}$ & 0.4384 & 0,8988 & 0,4877 & $71^{\circ}$ & 0,9455 & 0.3256 & 2.9042 \\
\hline $27^{\circ}$ & 0,4540 & 0.8910 & 0.5095 & $72^{\circ}$ & 0.9511 & 0.3090 & 3.0777 \\
\hline $28^{\circ}$ & 0,4695 & 0.8829 & 0.5317 & $73^{\circ}$ & 0,9563 & 0.2924 & 3.2709 \\
\hline $29^{\circ}$ & 0,4848 & 0.8746 & 0.5543 & $74^{\circ}$ & 0.9613 & 0.2756 & 3.4874 \\
\hline $30^{\circ}$ & 0.5000 & 0.8660 & 0.5774 & $75^{\circ}$ & 0,9659 & 0.2588 & 3.7321 \\
\hline $31^{\circ}$ & 0.5150 & 0,8572 & 0.6009 & $76^{\circ}$ & 0.9703 & 0.2419 & 4,0108 \\
\hline $32^{\circ}$ & 0.5299 & 0.8480 & 0.6249 & $77^{\circ}$ & 0.9744 & 0.2250 & 4.3315 \\
\hline $33^{\circ}$ & 0,5446 & 0.8387 & 0.6494 & $78^{\circ}$ & 0.9781 & 0.2079 & 4.7046 \\
\hline $34^{\circ}$ & 0.5592 & 0,8290 & 0,6745 & $79^{\circ}$ & 0,9816 & 0,1908 & 4.1446 \\
\hline $35^{\circ}$ & 0.5736 & 0,8192 & 0.7002 & $80^{\circ}$ & 0,9848 & 0.1736 & 5,6713 \\
\hline $36^{\circ}$ & 0.5878 & 0.8090 & 0.7265 & $81^{\circ}$ & 0.9877 & 0,1564 & 6.3138 \\
\hline $37^{\circ}$ & 0.6018 & 0.7986 & 0,7536 & $82^{\circ}$ & 0,9903 & 0.1392 & 7.1154 \\
\hline $38^{\circ}$ & 0,6157 & 0.7880 & 0,7813 & $83^{\circ}$ & 0,9925 & 0.1219 & 8.1443 \\
\hline $39^{\circ}$ & 0.6293 & 0,7771 & 0.8098 & $84^{\circ}$ & 0,9945 & 0.1045 & 9.5144 \\
\hline $40^{\circ}$ & 0,6428 & 0.7660 & 0.8391 & $85^{\circ}$ & 0.9962 & 0,0872 & 11.4301 \\
\hline $41^{\circ}$ & 0.6561 & 0,7547 & 0.8693 & $86^{\circ}$ & 0.9976 & 0.0698 & 14.3007 \\
\hline $42^{\circ}$ & 0.6691 & 0,7431 & 0.9004 & $87^{\circ}$ & 0.9986 & 0.0523 & 19.0811 \\
\hline $43^{\circ}$ & 0,6820 & 0.7314 & 0,9325 & $88^{\circ}$ & 0.9994 & 0.0349 & 28.6363 \\
\hline $44^{\circ}$ & 0.6947 & 0.7193 & 0,9657 & $89^{\circ}$ & 0,9998 & 0,0175 & 57.2900 \\
\hline $45^{\circ}$ & 71 & & & & & & \\
\hline
\end{tabular}




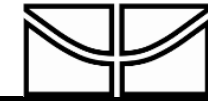 \\ Universidade de Brasília \\ Departamento de Matemática}

\section{Atividade 11}

\section{Pesquisa de opinião}

Nome: Data:

1. Você já conhecia o teodolito?

( ) Sim

( ) Não

2. Você já havia utilizado um teodolito?

( ) $\operatorname{Sim}$ ( ) Não

3. Você julgou interessante trabalhar com a Matemática em um ambiente fora de sala de aula, com atividades práticas?

( ) Sim

( ) Não

4. Você acredita que o projeto auxiliou na aprendizagem do conteúdo de Matemática que foi ministrado em sala de aula?

( ) Auxiliou muito ( ) Auxiliou pouco ( ) Não auxiliou

5. Você se sentiu motivado para participar das atividades do projeto?

( ) Muito motivado ( ) Pouco motivado ( ) Não

6. O seu interesse em aprender a matéria aumentou pelo fato de estar utilizando-a no projeto?

( ) Aumentou muito ( ) Aumentou pouco ( ) Não aumentou

7. Qual dos conteúdos você sentiu maior facilidade?

( ) Raiz quadrada

( ) Média aritmética

( ) Dízima periódica

( ) Medidas de comprimento

( ) Regra de três simples

( ) Teorema de Pitágoras

( ) Ângulos e uso do transferidor

( ) Uso do compasso

( ) Trigonometria 
8. Qual dos conteúdos você sentiu maior dificuldade?

( ) Raiz quadrada

( ) Média aritmética

( ) Dízima periódica

( ) Medidas de comprimento

( ) Regra de três simples

( ) Teorema de Pitágoras

( ) Ângulos e uso do transferidor

( ) Uso do compasso

( ) Trigonometria

9. Você deixou de aprender algum conteúdo?

( ) Raiz quadrada

( ) Média aritmética

( ) Dízima periódica

( ) Medidas de comprimento

( ) Regra de três simples

( ) Teorema de Pitágoras

( ) Ângulos e uso do transferidor

( ) Uso do compasso

( ) Trigonometria

10. Você pretende continuar utilizando o seu teodolito?

( ) Sim

( ) Não

11. Você indicaria o projeto para outros colegas?

( ) Sim

( ) Não

12. Dê uma nota de 0 a 10 para o projeto:

$\begin{array}{llllll}\text { ( ) } 1,0 & \text { ( ) } 2,0 & \text { ( ) } 3,0 & \text { ( ) } 4,0 & \text { ( ) } 5,0 \\ \text { ( ) } 6,0 & \text { ( ) } 7,0 & \text { ( ) } 8,0 & \text { ( ) } 9,0 & \text { ( ) } 10,0\end{array}$

13. O que o projeto representou para você? 


\section{Referências Bibliográficas}

[1] BRASIL. Ministério da Educação (MEC). Secretaria de Educação Média e Tecnológica. Parâmetros Curriculares Nacionais (PCNS): Ensino Médio. Brasília, 1999.

[2] BRASIL, Secretaria de Educação Fundamental. Parâmetros curriculares nacionais: Matemática. MEC/ SEF, 1998.

[3] D’AMBRÓSIO, Ubiratan. Da Realidade à Açãa - reflexões sobre educação e matemática, ed. Campinas -SP: Ed. Da Universidade Estadual de Campinas, 1986.

[4] D’AMBRÓSIO, Ubiratan. Educação Matemática: da teoria à prática, ed. Campinas, SP: Papirus, 2012.

[5] FREIRE, Paulo. Pedagogia da Autonomia: Saberes Necessários à Prática Educativa, ed. São Paulo: Paz e Terra, 2011.

[6] GOMES, Maria Laura Magalhães. História do ensino da Matemática: uma introdução, Belo Horizonte, CAED-UFMG, 2012. Disponível em http://www.mat.ufmg.br/ead/acervo/livros/historia\%20do\%20ensino\%20da\%20 matematica.pdf (17/07/2015 as 12h).

[7] HengemÜHLE, Adelar. Gestão de Ensino e Práticas Pedagógicas, ed. Rio de Janeiro: Vozes, 2004.

[8] LAKATOS, E. M. e MARCONI, M. A. Fundamentos de metodologia. São Paulo: Atlas, 2001.

[9] MARKARIAN, R. A matemática na escola: Alguns problemas e suas causas. Revista do Professor de Matemática. v. 38, n. 38, p. 23-32, 1998.

[10] MATTAR, Fauze Najib. Pesquisa de Marketing, ed. Rio de Janeiro: Elsevier, 2012. 
[11] MENDES, Iran Abreu. A Trigonometria e o seu ensino: alguns fragmentos dessa história. Universidade Federal do Ceará. Disponível em http://sbhe.org.br/novo/congressos/cbhe2/pdfs/Tema7/0737.pdf (em 26/07/2015 as $10 \mathrm{~h} 30)$.

[12] PIAGET, Jean. Psicologia e pedagogia. Ed. São Paulo: Summus, 1984.

[13] Revista Carta Capital - Educação - Opinião - Os problemas da educação no Brasil, por Paulo Yokota - publicada em 14/04/2014.

[14] Revista ISTOÉ, edição no 2289, seção comportamento, publicada em 27 de setembro de 2013.

[15] SANCHEZ, Jesus-Nicásio Garcia. Dificuldades de aprendizagem e intervenção psicopedagógica. Ed. Artmed, Porto Alegre, 2004.

[16] SCHLIEMAnN, Ana Lúcia, CARRAHER, Terezinha e CARRAHER, David. Na vida dez, na escola zero. Editora Cortez. São Paulo, 1997.

[17] SCHNEIDER, L, C. Matemática: o processo de Ensino-Aprendizagem. 2007. Disponível em http://www.somatematica.com.br/artigos/a32/ acessado em $23 / 07 / 2015$.

[18] SILVA, José Augusto Florentino da. Refletindo sobre as dificuldades de aprendizagem na Matemática: algumas considerações. UCB, 2005. Disponível em https://www.ucb.br/sites/100/103/TCC/22005/JoseAugustoFlorentinodaSilva.pdf (19/07/2015).

[19] SMITH, Corine; STRICK Lisa. Dificuldades de aprendizagem de a a z. Porto Alegre: Artmed, 2001.

[20] TAPIA, Jésus Alonso; FITA, Enrique Caturba. A motivação em sala de aula: o que é, como se faz, ed. São Paulo: Edições Loyola, 2006.

[21] TIBA, Içami. Ensinar aprendendo: novos paradigmas da educação, ed. São Paulo: Integrare Editora, 2006.

[22] TOledo, Marília e TOLEDO, Mauro. Didática de matemática como dois e dois: a construção da matemática. Editora FTD. São Paulo, 1997.

[23] VERGNAUD, G., Epistemology and Psiclogy in Mathematicis Education, Mathematicis and Cognition, Nesher,P e Kilpatrik,J., Cambridgge University Press, 1994, pp 2-17. 
[24] ZILKHA, Esther. Utilização do Geogebra na construção de instrumentos - Teodolito, Rio de Janeiro, 2014. http://www.impa.br/opencms/pt/ensino/downloads/PROFMAT/trabalho_conclu sao_curso/2014/esther-zilkha.pdf (disponível em 15/06/15).

[25] http://revistaescola.abril.com.br/formacao/serie-especial-historia-educacao-brasil750345.shtml (disponível em 18/07/2015).

[26] http://downloadinep.gov.br/acoes-internacionais/pisa/resultados/2014/relatorio -nacional-pisa-2012-resultados-brasileiros.pdf (disponível em 15/07/2015).

[27] http://www.clicrbs.com.br/especial/rs/precisamosderespostas/19,1430,3869663, Por-que-o-Brasil-esta-no-88-lugar-no-ranking-mundial-da-educacao.html (disponível em 18/07/2015).

[28] https://aprendendoaensinar.wordpress.com/2010/02/19/a-evolucao-da-educacaomatematica/ (disponível em 16/07/2015).

[29] http://www1.folha.uol.com.br/educacao/2013/12/1380024-brasil-teve-grandeavanco-no-pisa-afirma-mercadante.shtml (disponível em 19/07/2015).

[30] http://g1.globo.com/educacao/noticia/2013/12/brasil-evolui-mas- segue-nasultimas-posicoes-em-ranking-de-educacao.html (disponível em 09/07/2015).

[31] http://revistaescola.abril.com.br/matematica/fundamentos/fundamentacaodidatica-ensino-matematica-428262.shtml (disponível em 19/07/2015).

[32] http://www.mast.br/multimidia_instrumentos/teodolito.html (disponível em $23 / 07 / 2015)$.

[33] http://ecalculo.if.usp.br/historia/historia_trigonometria.htm (disponível em 04/05/2015).

[34] http://www.esaas.com/grupos/matematica/estagios/Paginas/HiparcoDeNiceia.htm (disponível em 04/05/2015).

[35] http://www.se.df.gov.br/educacao-df/rede-publica/numeros-da- educacao/270total-de-escolas-publicas.html (disponível em 31/07/2015).

[36] revista.arquivonacional.gov.br/index.php/revistaacervo/article/view/184 (disponível em 08/11/2015). 
[37] www.observatoriodopne.org.br/uploads/reference/file/193/documentoreferencia.pdf (disponível em 08/11/2015). 